UNIVERSIDADE DE SÃO PAULO

INSTITUTO DE GEOCIÊNCIAS

\title{
ANÁLISE ESPACIAL DE VULNERABILIDADE A VAZAMENTOS EM REDE DE ABASTECIMENTO DE ÁGUA
}

Vanessa Amadi Barros Rauen

Orientador: Prof. Dr. Carlos Henrique Grohmann de Carvalho

DISSERTAÇÃO DE MESTRADO

Programa de Pós-Graduação em Recursos Minerais e Hidrogeologia

SÃO PAULO

2014 
UNIVERSIDADE DE SÃO PAULO

INSTITUTO DE GEOCIÊNCIAS

\section{ANÁLISE ESPACIAL DE VULNERABILIDADE A VAZAMENTOS EM REDE DE ABASTECIMENTO DE ÁGUA}

Vanessa Amadi Barros Rauen

Orientador: Prof. Dr. Carlos Henrique Grohmann de Carvalho

DISSERTAÇÃO DE MESTRADO

Programa de Pós-Graduação em Recursos Minerais e Hidrogeologia

SÃO PAULO 
Autorizo a reprodução e divulgação total ou parcial deste trabalho, por qualquer meio convencional ou eletrônico, para fins de estudo e pesquisa, desde que citada a fonte.

Ficha catalográfica preparada pelo Serviço de Biblioteca e Documentação do Instituto de Geociências da Universidade de São Paulo

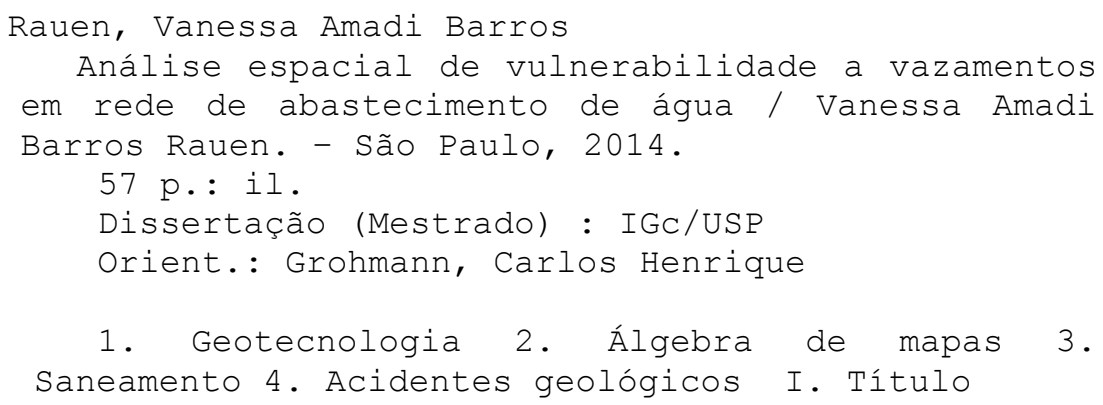




\section{AGRADECIMENTOS}

Agradeço primeiramente a Deus, que permitiu que eu iniciasse e concluísse este trabalho e que me deu saúde e força para enfrentar os momentos difíceis.

À minha família, que são tudo que tenho de mais precioso. Minha mãe, guerreira, que sempre batalhou por minha formação, meu exemplo de dedicação e integridade. Meus avós, Edgar e Antonietta, que são a base da minha vida. Minha irmã Thaíssa, minhas tias Gi, Ellen e Pi (in memorian), que sempre estiveram ao meu lado, me apoiando e acreditando em mim. Às minhas queridas primas, Bruna, Amanda, Maria Fernanda, aos primos Andrés e Matheus e aos tios Fabrício e Marcos pelos momentos de carinho e descontração.

Ao Professor Dr. Antônio Conceição Paranhos Filho (Toni) que me recebeu de braços abertos, me orientou desde o início, confiou em mim e não me permitiu esmorecer.

À Camila Mioto, um anjo que Deus colocou em minha vida, uma irmã de coração, que me apoiou no desenvolvimento e conclusão deste trabalho, acreditou no meu potencial e me aguentou em momentos muito difíceis.

Ao SAAE, pela parceria estabelecida e por permitir o desenvolvimento desta pesquisa. Aos companheiros de trabalho: Nadia, Aguinaldo, Roger, Lygia, Luizinho, Saulio, Cris Costrov, Fernandinho, Elaine, Sônia e aos demais pela compreensão e apoio. Ao DMO, que através do Marco Aurélio, Daniel, Rodrigo, Jorginho, Aline, Priscila, Ana Paula e Pedrão me auxiliaram e me colocaram em contato do tema abordado neste trabalho. Agradeço também ao DRC e a Tatiana, por me ajudar no levantamento de dados.

Ao Márcio Almeida, que me auxiliou no desenvolvimento das simulações, me ajudou a desenvolver ideias e conferiu o trabalho.

Aos amigos de sempre, irmãos de Floripa (Karina, Claudia, Sandrinha, Vanessa, Natti, Cris e Felipe) e os mais antigos de Lucélia. 
À Aline Hasegawa, pela amizade, motivação e apoio no desenvolvimento e conclusão do trabalho.

Ao amigo Sidney Goveia, que me incentivou a iniciar este mestrado e acreditou em mim. Agradeço também pelas discussões sempre produtivas, ideias e companheirismo.

À USP, que me deu a oportunidade de desenvolver este trabalho, ao pessoal da Secretaria da Pós e aos amigos que lá fiz: Aníbal, Fabrício, Marcus, Rafael, Paulo e demais. E também ao Santiago que me apoiou durante a qualificação. Ao Prof. Edilson Pissato, pelas discussões, auxílio e orientações.

À Universidade de Guarulhos, pela disponibilização dos dados e auxílio dos professores Antônio Manoel Oliveira, Márcio Andrade e William Queiroz.

À Universidade Federal do Mato Grosso do Sul, que me recebeu no Laboratório de Geoprocessamento para Aplicações Ambientais e que auxiliou no desenvolvimento dos mapas elaborados, através do Leandro, Guilherme e demais.

Finalizando, ao professor e orientador Carlos Henrique Grohmann de Carvalho, que acreditou em mim desde o início e que muito contribuiu para a conclusão com êxito deste trabalho.

E a todos que direta ou indiretamente estiveram envolvidos nesta conquista, meu muito obrigada! 


\section{RESUMO}

Rauen, V. A. B. Análise espacial de vulnerabilidade a vazamentos em rede de abastecimento de água. 2014. p. 67. Dissertação (Mestrado) - Instituto de Geociências, Universidade de São Paulo, São Paulo.

A presente pesquisa foi desenvolvida no Município de Guarulhos, situado a nordeste da capital São Paulo e segundo município em número de habitantes do Estado. O objetivo deste trabalho é elaborar cartas de vulnerabilidade para o Município, visando identificar, num primeiro momento, a suscetibilidade intrínseca ao meio físico à ocorrência de acidentes geológicos induzidos por vazamentos da rede de abastecimento de água. Posteriormente, com o levantamento de dados do sistema de abastecimento de água o intuito é elaborar um mapa identificando áreas vulneráveis à ocorrência de vazamentos e, desta forma, auxiliar a companhia de saneamento na definição de áreas prioritárias para o controle de vazamentos. Estes mapas foram elaborados através da metodologia de álgebra de mapas desenvolvida em ambiente SIG, em que foram definidos fatores desencadeantes e seus respectivos pesos conforme a influência na deflagração dos eventos estudados. Para o desenvolvimento do mapa de vulnerabilidade natural foram cruzados os mapas de geologia, pedologia e declividade e ao resultado desse procedimento foi adicionado o mapa de uso do solo e o resultado foi o mapa de vulnerabilidade ambiental. Ao analisar-se o mapa de vulnerabilidade natural verificou-se que no compartimento norte as maiores vulnerabilidades estão associadas ao fator declividade, enquanto que no compartimento sul os maiores valores estão associados à pedologia. Quando analisamos o mapa de vulnerabilidade ambiental, observa-se que a maior parte do Município encontra-se em área de baixa vulnerabilidade, em função da área ao norte encontrar-se preservada. Porém, se analisarmos somente as áreas urbanizadas a vulnerabilidade ambiental predominante passa a ser média a muito vulnerável. Neste caso, as altas vulnerabilidades estiveram associadas a terrenos Cenozóicos e altas declividades. Posteriormente procedeu-se à análise da vulnerabilidade à ocorrência de vazamentos da rede de abastecimento de água. Nesta etapa foram utilizados na álgebra de mapas os fatores de idade, pressão da rede e número de manutenções recorrentes. Os maiores valores de vulnerabilidade ocorreram nas redes que já haviam sofrido manutenções recorrentes, porém ao lançarmos no mapa os acidentes geológicos que foram levantados, estes estiveram associados a áreas de alta ou média vulnerabilidades. Desta forma, pode-se concluir que os 
demais fatores analisados (idade e pressão) tiveram maior influência na deflagração desses eventos. Sendo assim é possível concluir que a metodologia aplicada mostrou-se satisfatória aos objetivos propostos. É importante salientar que a metodologia pode ser integralmente desenvolvida em programas livres e gratuitos de SIG, facilitando desta maneira o acesso de órgãos públicos.

Palavras-chave: Geotecnologias; Álgebra de Mapas; Saneamento; Acidentes geológicos. 


\begin{abstract}
Rauen, V. A. B. Análise espacial de vulnerabilidade a vazamentos em rede de abastecimento de água. 2014. p. 67. Dissertação (Mestrado) - Instituto de Geociências, Universidade de São Paulo, São Paulo.
\end{abstract}

This research was conducted in the city of Guarulhos, located northeast of the capital São Paulo municipality and second in number of inhabitants of the State. The objective of this work is to develop maps of vulnerability for the city, to identify, at first, the intrinsic susceptibility to physical environment to the occurrence of geological accidents induced by leakage from water supply network. Later, with the survey data of the water supply, system the aim is to develop a map identifying vulnerable areas to spillage and thus, help the sanitation company to define priority areas for leakage control. These maps were produced using the methodology of map algebra developed in GIS environment, in which triggering factors and their respective weights were defined as the influence on the outbreak of the studied events. Thus, for the development of the natural vulnerability map, maps of geological, pedological and slope and the result of this procedure was added to the map of land use and the result was the map of environmental vulnerability. When we analyze the map of environmental vulnerability, it is observed that most of the city lies in an area of low vulnerability, due to the area north be preserved. However, if we analyze only the urbanized areas, the predominant environmental vulnerability becomes medium to very vulnerable. In this case, the high vulnerabilities were associated with Cenozoic terrains and steep slopes. Subsequently, we proceeded to the analysis of vulnerability to the occurrence of leaks in water supply network. In this stage we used map algebra factors of age, network pressure and number of recurring maintenance. The highest vulnerability occurred in networks that had already suffered recurring maintenance, but as we launched to the map the geological accidents that were surveyed, these were associated with areas of high or medium vulnerabilities. Thus, it can be concluded that other factors analyzed (age and pressure) had greatest influence in the initiation of these events. Thereby it can be concluded that the methodology applied was satisfactory to the proposed objectives. It is important to mention 
that the methodology can be fully developed free programs in GIS, which facilitate the access to public agencies.

Keywords: Geotechnology; Map Algebra; Sanitation; Geological Accidents. 


\section{SUMÁRIO}

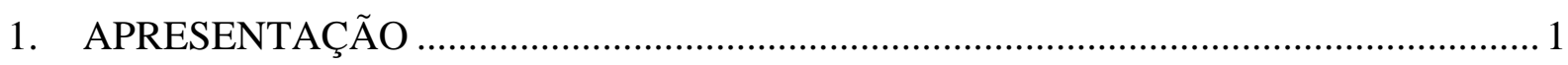

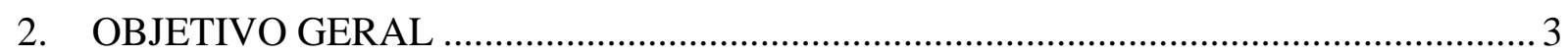

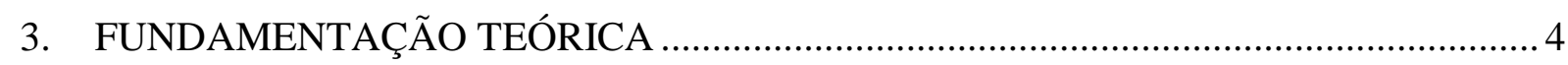

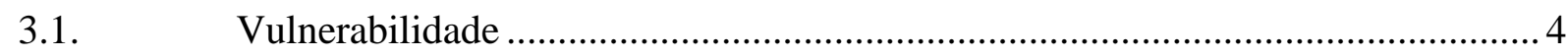

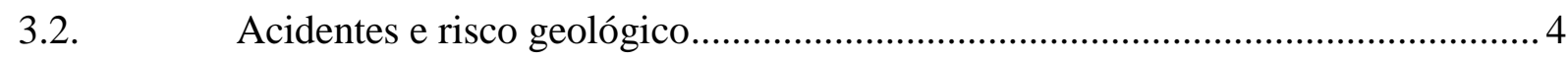

3.2.1. Movimentos de massa …………………………………….....................................

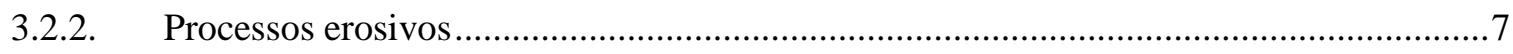

3.2.3. Fatores condicionantes ..................................................................................

3.3. Estrutura dos sistemas de abastecimento de água ................................................. 10

3.3.1. Controle de Perdas .........................................................................................11

3.3.2. Condicionantes do rompimento de tubulações de água ..............................................12

3.3.3. Modelagem hidráulica de Sistemas de Abastecimento de Água....................................12 3.4. Acidentes geológicos urbanos associados a vazamentos da rede de abastecimento de água..................................................................................................13

4. VULNERABILIDADE AMBIENTAL E NATURAL DO MUNICÍPIO DE

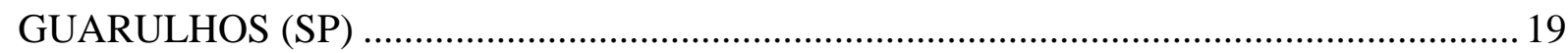

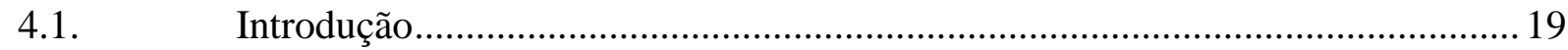

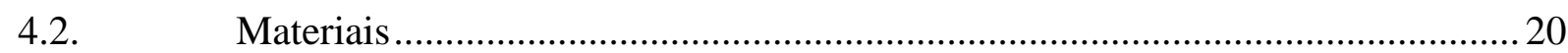

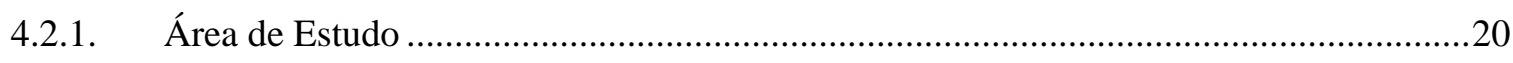

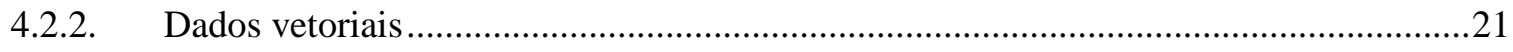

4.2.1. Levantamento dos acidentes geológicos em Guarulhos .......................................32

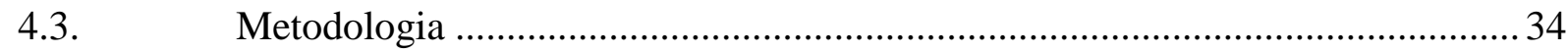

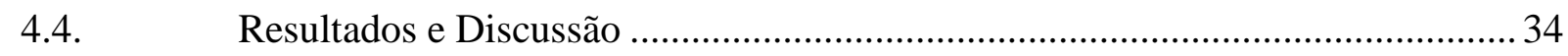

4.4.1. Vulnerabilidade Natural ............................................................................................

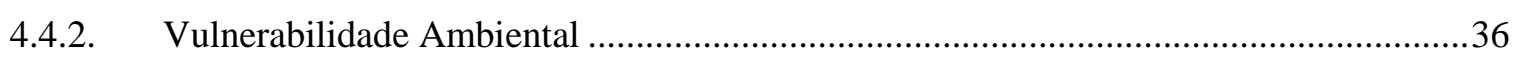

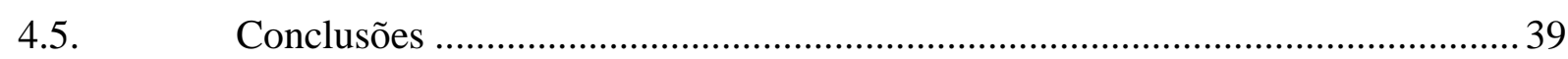

5. GEOTECNOLOGIAS PARA DETERMINAÇÃO DE VULNERABILIDADE À OCORRÊNCIA DE VAZAMENTOS NA REDE DE ABASTECIMENTO DE ÁGUA ........40

5.1. Introdução. 


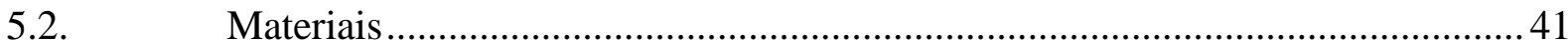

5.2.1. Sistema de abastecimento de água de Guarulhos ............................................................41

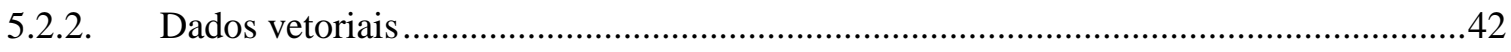

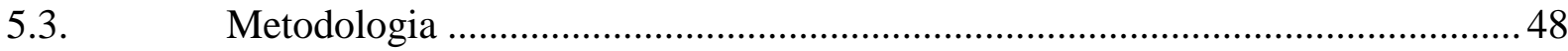

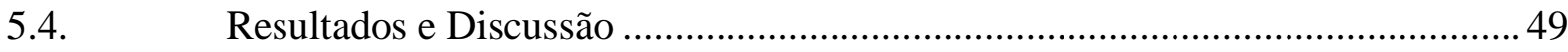

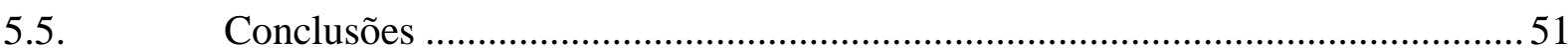

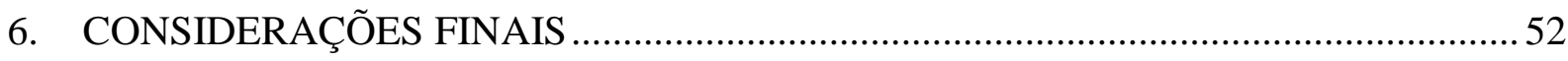

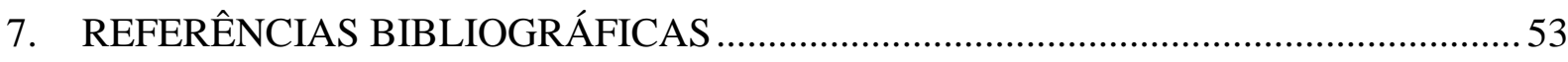




\section{LISTA DE FIGURAS}

Figura 1. Configuração geral de um sistema de abastecimento de água (Orsini,1996). . 10 Figura 2. Enorme cratera que se formou em Harrisburg, Estados Unidos, em decorrência de um vazamento da rede de abastecimento de água. Fonte: Lancaster Online 14 Figura 3. Grande movimentação do solo ocorrida em Lakeport, Estados Unidos, em função de vazamento de água da rede de 50mm. Fonte: ABC Local.

Figura 4. Cratera encontrada na Rua Oscar Freire, São Paulo. Em função de vazamento da rede de abastecimento de água. Fonte: O Estado de São Paulo Online 16 Figura 5. Fissuras que indicam a movimentação do solo em residências da Ponte Grande, Guarulhos. Fonte: SAAE Guarulhos

Figura 6. Local do rompimento da rede de abastecimento de água e comprometimento de imóvel próximo. Fonte: SAAE Guarulhos

Figura 7. Movimentação do solo em imóvel no Recreio São Jorge, Guarulhos. Fonte: SAAE Guarulhos 18

Figura 8. Município de Guarulhos e seus respetivos bairros.

Figura 9. Mapa Geológico de Guarulhos. Adaptado de: Oliveira et al, 2009. 23

Figura 10. Mapa Pedológico de Guarulhos. Adaptado de: Oliveira et al, 2009. ........... 26

Figura 11. Mapa geomofológico de Guarulhos. Adaptado de: Oliveira et al, 2009 ....... 28

Figura 12. Mapa de declividade de Guarulhos Adaptado de: Oliveira et al, 2009......... 29

Figura 13. Mapa de Uso do Solo de Guarulhos. Adaptado de: Oliveira et al, 2009....... 30

Figura 14. Mapa de vulnerabilidade natural do Município de Guarulhos, SP. 35

Figura 15. Casos de acidentes registrados lançados sobre o mapa de vulnerabilidade natural 36

Figura 16. Mapa de vulnerabilidade ambiental do Município de Guarulhos, SP. 37

Figura 18. Diagramas de Voronoi dos valores de pressão para o Município de Guarulhos. 44

Figura 19 Distribuição das faixas etárias da rede de água de Gualhos. 46

Figura 20. Número de manutenções na rede de distribuição de água em Guarulhos. .... 48 Figura 21. Carta de vulnerabilidade à ocorrência de vazamentos na tubulação de distribuição de água do Município de Guarulhos, SP.

.Figura 22. Casos de acidentes geológicos sobre a carta de vulnerabilidade a vazamentos. 


\section{LISTA DE TABELAS}

Tabela 1. Características dos principais tipos de deslizamentos que ocorrem no Brasil

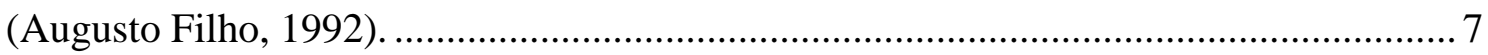

Tabela 2. Valores de estabilidade conforme Tricart (1977)........................................ 22

Tabela 3. Pesos estabelecidos para as classes de Geologia........................................... 24

Tabela 4 Pesos atribuídos para as classes de declividade. ...............................................2 29

Tabela 5. Valores estabelecidos para cada classe de uso do solo. ................................. 31

Tabela 6. Acidentes levantados em Guarulhos, SP................................................... 32

Tabela 7. Ponderação dos fatores para análise das vulnerabilidades. ............................ 34

Tabela 8.Valores de vulnerabilidade natural do Município de Guarulhos....................... 36

Tabela 9. Valores de vulnerabilidade ambiental do Município de Guarulhos................ 37

Tabela 10. Pesos estabelecidos para cada classe de pressão.......................................... 44

Tabela 11. Faixa etária das redes x extensão - Município de Guarulhos. Fonte: SAAE

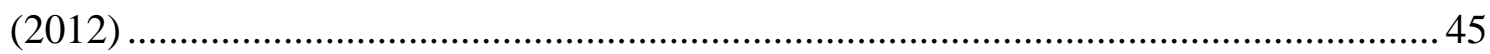

Tabela 12. Valores estabelecidos para as faixas etárias da rede de água........................ 46

Tabela 13. Pesos estabelecidos para as faixas de manutenção na rede........................... 48

Tabela 14. Valores encontrados para cada classe de vulnerabilidade à ocorrência de

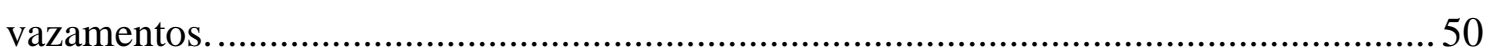




\section{LISTA DE SIGLAS}

ANA - Agência Nacional de Águas

CX - Cambissolos

DAAE - Departamento de Águas e Energia Elétrica

ETA - Estação de Tratamento de Água

FF - Plintossolo

GM1 - Gleissolo

IPT - Instituto de Pesquisas Tecnológicas

IWA - Institute Water Association

$\mathrm{KPa}$ - Kilopascal

LVA - Latossolo Vermelho Amarelo

Mca - Metro de coluna d'água

MINEROPAR - Serviço Geológico do Paraná

NBR - Norma Brasileira

ONU - Organização das Nações Unidas

PEMAS - Plano Estratégico Municipal para Assentamentos Subnormais.

PLHIS - Plano Local de Habitação de Interesse Social

PMG - Prefeitura Municipal de Guarulhos

PROSAB - Programa de Pesquisas em Saneamento Básico

PVA - Argissolo Vermelho Amarelo

QGIS - Quantum GIS

RL - Neossolo litólico

RMSP - Região Metropolitana de São Paulo

SAAE - Serviço Autônomo de Água e Esgoto

SAAs - Sistemas de Abastecimento de Água

SABESP - Companhia de Saneamento Básico de São Paulo

SAD - South American Datum

SIG - Sistema de Informação Geográfica

SNIS - Sistema Nacional de Informações de Saneamento

SW-NE - Sudoeste - nordeste

USGS - United States Geological Survey

UTM - Universal Transversa de Mercator

VA - Vulnerabilidade Ambiental 
VN - Vulnerabilidade Natural 


\section{APRESENTAÇÃO}

Como sociedade globalizada, estamos em constante contato com notícias sobre acidentes geológicos que implicam em danos humanos ou materiais. Escorregamentos, inundações, ressacas, temporais, entre outros, tornam-se cada vez mais frequentes na mídia mundial e o número de atingidos converte uma questão de ordem natural em problema público.

A concentração demográfica decorrente do progressivo processo de urbanização não planejada induz a pressão sobre o meio e o que se vê é o aumento da ocupação de áreas geograficamente desfavoráveis. Em se tratando de ocupação de áreas de risco, os fatores geográficos não são os únicos a serem levados em consideração no que se refere à periculosidade colocada às habitações, visto que fatores socioeconômicos têm destacado valor na análise de eventos dessa natureza, tornando-se importante o estudo e planejamento do território como forma de identificação e prevenção da ocupação de áreas desfavoráveis.

Além de causas naturais, os acidentes geológicos também podem ser ocasionados por causas antrópicas. O adensamento da ocupação em encostas, eliminando a vegetação nativa, a execução de cortes e aterros em vertentes e o lançamento de resíduos sólidos nessas áreas estão entre alguns dos condicionantes antrópicos desses eventos.

Esta pesquisa se concentrou na análise de um fator antrópico específico causador de movimentos de massa e processos erosivos: os vazamentos da rede de abastecimento de água. Desta maneira, este trabalho busca contribuir para a prevenção de acidentes geológicos no Município de Guarulhos - SP, por meio da identificação das áreas vulneráveis à ocorrência desses eventos.

O desenvolvimento deste trabalho foi orientado a partir da necessidade de análise de eventos que afetam com frequência as companhias de saneamento e usuários, e que envolvem duas grandes áreas de estudo pouco relacionadas em bibliografias: a geologia e o saneamento. Assim, a pesquisa teve como objetivo analisar as consequências dos vazamentos da rede de abastecimento de água no meio físico através da predisposição do meio à ocorrência de movimentos do solo e processos erosivos, identificado através das vulnerabilidades. Essas áreas foram identificadas através de técnicas de geoprocessamento e poderão servir de auxílio na prevenção de prejuízos oriundos desses processos, através da priorização de áreas para controle.

Essa dissertação é apresentada no formato de dois capítulos de desenvolvimento, que tratam principalmente da técnica de álgebra de mapas por meio de geotecnologias para definir 
áreas vulneráveis à ocorrência de processos geológicos. Por ser escrito nessa forma, o conteúdo pode se repetir eventualmente, porém cada capítulo apresenta materiais e métodos, resultados e conclusões próprias.

O primeiro capítulo de desenvolvimento intitulado "Vulnerabilidade ambiental e natural no Município de Guarulhos - SP” trata da identificação de áreas suscetíveis à ocorrência de processos geológicos por meio de fatores intrínsecos à área estudada, sendo eles: a geologia, solos, declividade e uso e ocupação do município.

O segundo capítulo de desenvolvimento, apresentado no item 5, é denominado “Geotecnologias para determinação de vulnerabilidade à ocorrência de vazamentos na rede de abastecimento de água", e trata especificamente da identificação de áreas suscetíveis à ocorrência de vazamentos de água, buscando contribuir para identificação de áreas prioritárias, tanto para o controle de vazamentos, quanto para acidentes geológicos induzidos por estes.

O início do ano de 2014 têm sido memorável para os habitantes do Estado de São Paulo, pois sofre com a pior média pluviométrica para este período em 84 anos de monitoramento. A vazão afluente ao Sistema Cantareira (responsável por abastecer mais de oito milhões de pessoas na região metropolitana do Estado) foi $60 \%$ inferior ao menor valor registrado (ANA e DAAE, 2014). A situação do Sistema Produtor Alto Tietê também é preocupante, ao passo que abastece aproximadamente quatro milhões de pessoas e em agosto apenas $16 \%$ de seu volume total estava preenchido (SABESP, 2014). O Município de Guarulhos depende de ambos os mananciais para garantir o abastecimento de seus habitantes, por meio da compra por atacado da SABESP de $87 \%$ da água distribuída (SAAE GUARULHOS, 2014).

Dentro deste cenário atual, trabalhar com controle de vazamentos de água torna-se essencial para garantir a sustentabilidade nos sistemas de abastecimento, de forma que ao combater vazamentos assegura-se que uma maior porcentagem do volume de água que entra no sistema possa chegar até o usuário final. 


\section{OBJETIVO GERAL}

O objetivo geral desta pesquisa é elaborar cartas que identifiquem áreas vulneráveis à ocorrência de processos erosivos e movimentos de massa, bem como áreas em que vazamentos da rede de abastecimento de água possam induzir a esses processos no Município de Guarulhos - SP e, com isso, auxiliar na tomada de decisão, definindo as áreas que devem receber maior atenção por parte das companhias de saneamento. 


\section{FUNDAMENTAÇÃO TEÓRICA}

\subsection{Vulnerabilidade}

Este trabalho tratará, essencialmente, da vulnerabilidade do meio físico. Portanto, para que não restem dúvidas quanto à abordagem deste termo, é adequado que seja apresentada sua conceituação teórica.

O fundamento de vulnerabilidade tratado neste trabalho advém do estudo publicado pelo Ministério do Meio Ambiente (BRASIL, 2007), que define o conceito como sendo a resposta do meio a partir de uma determinada perturbação, através de características intrínsecas à área de estudo. Desta forma, cada fração de território tem uma condição específica que, dependendo do tipo e magnitude do evento induzido, resulta numa grandeza de efeitos adversos, denominada vulnerabilidade. Esta mesma publicação cita que para o estudo de deslizamentos a conceituação de vulnerabilidade utilizada pela ONU (2004) é considerada mais conveniente, a qual define o termo como sendo a associação de processos e condições decorrentes de fatores físicos, sociais, econômicos e ambientais, os quais indicam o quanto uma comunidade ou elemento em risco estão suscetíveis ao impacto dos eventos perigosos.

Deste modo, é possível perceber como a definição dos conceitos envolvidos na análise de risco torna-se complexa, à medida que dentro de um mesmo estudo o termo de vulnerabilidade pode ser entendido também como a suscetibilidade do meio. Porém, este trabalho não pretende analisar essas questões etimológicas-conceituais, podendo ser entendida a suscetibilidade também como sinônimo de vulnerabilidade.

No presente trabalho, inicialmente utilizou-se aspectos intrínsecos do meio (declividade, aspectos geológicos e pedológicos) para identificar áreas potenciais para as ocorrências de acidentes geológicos. Posteriormente, ao adicionar-se os elementos expostos à suscetibilidade, ou seja, o uso e ocupação do solo e informações da rede de abastecimento de água, analisou-se com o conceito de vulnerabilidade do meio.

\subsection{Acidentes e risco geológico}

O crescimento populacional e ampliação da paisagem urbana leva a ocupação de áreas sem um planejamento que respeite as características físicas do local, resultando em processos que alteram a dinâmica do solo e culminam em acidentes geológicos. 
Neste trabalho, o termo 'acidente geológico urbano' será utilizado segundo a definição do Serviço Geológico do Paraná (MINEROPAR, 2010). Assim, esse termo será utilizado para se referir ao resultado da propagação e evolução dos processos de alteração do meio físico, provocados ou agravados pelo uso e ocupação do solo, que trazem como resultado agravos ambientais, sociais e econômicos, podendo trazer até mesmo a morte de pessoas. Desse modo, para a simplificação, será empregado o termo 'acidentes geológicos', o qual envolverá os eventos de movimentos de massa e os processos erosivos, os quais são os principais fenômenos provocados por vazamentos na rede de abastecimento de água.

Já a definição de risco geológico foi realizada por Cerri e Amaral (1998), que conceituaram de forma bastante clara o fenômeno: "a análise do risco envolve a possibilidade de que o processo geológico (induzido ou não) seja acompanhado de danos e perdas (acidente)". Ao analisar o fenômeno estudado, ou seja, acidentes geológicos induzidos por vazamentos da rede de abastecimento de água, pode-se classificar o evento como 'acidente', visto que um vazamento no mínimo causa um dano à tubulação rompida, que onera custos à companhia de saneamento, além da possibilidade de ocorrer falta de abastecimento na área de influência da rede que sofreu o dano. No presente estudo, trabalharemos também com o conceito de 'risco', visto que identificaremos possíveis áreas de ocorrência para os acidentes geológicos.

\subsubsection{Movimentos de massa}

O termo em inglês landslide, traduzido em geral como deslizamento, descreve a larga variedade de processos que resultam em movimentos externos e descendentes de encostas formadas por materiais como rocha, solo, aterro ou a combinação destes (USGS, 2004).

Tominaga, Santoro e Amaral (2009) definiram como movimento de massa o movimento do solo, rocha e/ou vegetação ao longo da vertente, que acontece sob influência direta da gravidade. Outros meios, como a água e o gelo, por exemplo, contribuem diminuindo a resistência dos materiais de vertente e/ou pela indução do comportamento plástico e fluido do solo.

Os movimentos de massa foram classificados segundo diversos autores, que seguiram diferentes critérios de classificação. Uma das classificações mais utilizadas foi desenvolvida por Varnes (1978 apud USGS, 2004), que divide os movimentos de massa segundo o tipo de movimento e o tipo de material transportado. O brasileiro Augusto Filho 
(1992) dividiu os movimentos de massa em quatro tipos principais: rastejos, escorregamentos, quedas e corridas.

Os rastejos constituem movimentos lentos e graduais, induzidos pela alta declividade do terreno. São indícios desse processo a ocorrência de muros e estruturas embarrigadas, trincas em paredes, árvores inclinadas, e degraus de abatimento formados nas encostas.

Os escorregamentos são processos que ocorrem com velocidade média a rápida, ocorrem de formas diferentes em função do tipo de solo e/ou rocha e do relevo. Os escorregamentos são classificados dependendo da geometria e dinâmica de movimentação, as formas mais comuns são os escorregamentos planares, os circulares e em cunha.

As quedas incluem movimentos associados a materiais rochosos, que se desenvolvem com geometria variável e em velocidades normalmente altas. Os principais tipos de movimentação agrupados nesta categoria são: quedas de blocos, tombamentos de blocos, rolamento de blocos (matacões) e desplacamentos de lascas e blocos de rochas.

Já as corridas são decorrentes de chuvas muito intensas, que provocam a mobilização de solo, rocha e detritos ao longo das drenagens. São movimentos que transportam grandes volumes de material com velocidade elevada, por isso constituem eventos com alto poder destrutivo.

A classificação de Augusto Filho (1992) é ilustrada através da Tabela 1.

Os movimentos de massa podem ser influenciados por várias feições, as quais atuam como fatores condicionantes, definindo o local e o tempo destes movimentos em campo. A maioria dessas feições apresenta sua origem relacionada a processos geológicos e geomorfológicos que agiram no passado e que ainda atuam naqueles locais (FERNANDES e AMARAL, 2003).

Dentre as principais alterações originadas da intervenção do homem e que influenciam os movimentos de massa estão a retirada da cobertura vegetal, a realização de cortes e aterros inadequados, a saturação do solo devido ao lançamento e à concentração de águas pluviais e de esgoto, a presença de fossas, os vazamentos na rede de distribuição de água, o lançamento de lixo em locais inadequados (encostas e taludes), o cultivo inadequado do solo, entre outros (MINEROPAR, 2010).

No presente trabalho se utilizará os termos deslizamento e movimento de massa, como sinônimos, isto é, para qualquer processo de movimento gravitacional, independente do 
tipo de material, dos mecanismos de ruptura, das velocidades de movimento e da geometria do material movimentado.

Tabela 1. Características dos principais tipos de deslizamentos que ocorrem no Brasil (Augusto Filho, 1992).

\begin{tabular}{|c|c|}
\hline PROCESSOS & $\begin{array}{l}\text { CARACTERÍSTICAS DO MOVIMENTO, MATERIAL } \\
\text { E GEOMETRIA. }\end{array}$ \\
\hline Rastejos & $\begin{array}{l}\text { - Vários planos de deslocamento (internos); } \\
\text { - Velocidades muito baixas (cm/ano) a baixas e decrescentes } \\
\text { como a profundidade; } \\
\text { - Movimentos constantes, sazonais ou intermediários; } \\
\text { - Solo, depósitos, rochas alterada/fraturada; } \\
\text { - Geometria indefinida. }\end{array}$ \\
\hline Escorregamentos & $\begin{array}{l}\text { - Poucos planos de deslocamentos (externos); } \\
\text { - Velocidades médias (m/h) a altas (m/s); } \\
\text { - Pequenos a grandes volumes de material; } \\
\text { PLANARES - solos poucos espessos, solos e rochas com um } \\
\text { plano de fraqueza; } \\
\text { CIRCULARES - solos espessos homogêneos e rochas muito } \\
\text { fraturadas; } \\
\text { EM CUNHA - solo rochas com dois planos de fraqueza. }\end{array}$ \\
\hline Quedas & $\begin{array}{l}\text { - Sem planos de deslocamento; } \\
\text { - Movimentos tipos queda livre ou em plano inclinado; } \\
\text { - Velocidades muito altas (vários } \mathrm{m} / \mathrm{s} \text { ); } \\
\text { - Material rochoso; } \\
\text { - Pequenos a médios volumes; } \\
\text { - Geometria variável: lascas, placas, blocos, etc; } \\
\text { - ROLAMENTO DE MATACÃO; } \\
\text { TOBAMENTO. }\end{array}$ \\
\hline Corridas & $\begin{array}{l}\text { - Muitas superfícies de deslocamentos (internas e externas à } \\
\text { massa em movimentação); } \\
\text { - Movimentos semelhantes ao de um líquido viscoso; } \\
\text { - Velocidades médias a altas; } \\
\text { - Mobilização de solo, rocha, detritos e águas; } \\
\text { - Grandes volumes de material; } \\
\text { - Extenso raio de alcance, mesmo em áreas planas. }\end{array}$ \\
\hline
\end{tabular}

\subsubsection{Processos erosivos}

Erosão é um fenômeno originado da ação concomitante de fatores que causam a separação e o transporte de partículas do solo ou de rocha sobre a superfície terrestre. O processe erosivo pode ser provocado pela ação da água, do vento, do gelo e de organismos, como os animais e plantas (MINEROPAR, 2010). 
A erosão desencadeada pelo escoamento superficial da água é dividida em dois tipos: erosão laminar e linear. O escoamento difuso é aquele responsável pela erosão laminar, que resulta na remoção progressiva e uniforme dos horizontes superficiais do solo, enquanto que o escoamento concentrado caracteriza o processo de erosão linear, instalado a partir do momento em que a velocidade do fluxo superficial vence a resistência mecânica do solo e consegue fazer incisões no terreno, em forma de sulcos, que podem evoluir, por aprofundamento, para ravinas (INFANTI JR. e FORNASARI FILHO, 1998).

Caso a erosão seja desenvolvida por fluxos de água subsuperficiais, incluindo a água proveniente de aquíferos, ocorre o processo conhecido como voçoroca ou boçoroca, com o desenvolvimento do piping, erosão interna ou tubular. Este fenômeno provoca a remoção de partículas do interior do solo, que formam canais que evoluem em sentido contrário ao fluxo da água, e que pode dar origem a colapsos do solo, com desabamentos que alargam a voçoroca ou criam novos ramos (TOMINAGA; SANTORO; AMARAL, 2009). O processo de piping é importante para este estudo, pois os vazamentos da rede de abastecimento de água constituem também um fluxo de água subsuperficial que pode atuar semelhantemente ao processo natural.

Mineropar (2010) destaca também que as atividades humanas constituem o principal fator na deflagração dos processos erosivos, podendo ser citados os desmatamentos, o cultivo inadequado de terras e a urbanização com a impermeabilização do solo, a concentração de drenagem por meio do lançamento de águas pluviais e servidas, o lançamento de efluentes, a redução de percursos, a implantação de estradas e rodovias, entre outros, onde podemos incluir também o fator de análise deste trabalho: os vazamentos da rede de abastecimento de água.

\subsubsection{Fatores condicionantes}

Genericamente, acidentes que envolvem a instabilidade de taludes são controlados por um conjunto de fatores, muitas vezes cíclicos, que têm sua origem associada à formação da rocha e suas modificações geológicas e geomorfológicas decorrentes, como intemperismo, ação antrópica ou erosão (AUGUSTO FILHO e VIRGILI, 1998).

Guidicini e Nieble (1976) destacam a distinção entre os conceitos dos termos 'agente' e 'causa'. Desta maneira, a 'causa' é definida como o modo de atuação de determinado 'agente', ou então, um 'agente' pode expressar-se por meio de uma ou mais 
'causas'. Esses agentes, ou fatores deflagradores, podem ser divididos em predisponentes ou efetivos.

Os agentes predisponentes referem-se ao conjunto de condições geológicas, geométricas e ambientais em que o movimento de massa ocorre, representam o 'pano de fundo' dessas ocorrências, função apenas de condições naturais, nunca antrópicas. Dentro desse conjunto de agentes incluem-se: o complexo geológico-geomorfológico, o complexo climático-hidrológico, a gravidade, o calor solar e o tipo de vegetação original da área.

Os agentes efetivos referem-se ao conjunto de elementos diretamente responsáveis pelo desencadeamento do movimento de massa, em que está inserida a ação antrópica. Podem atuar de forma mais ou menos direta na deflagração do processo, e assim são subdivididos em efetivos preparatórios e imediatos. Dentro dos efetivos preparatórios está a pluviosidade, erosão causada pela água ou vento e oscilação dos níveis de lagos, marés e também aquíferos freáticos. Já dentre os agentes efetivos imediatos estão as chuvas intensas, a erosão, os terremotos e as ondas.

As causas são distinguidas entre internas, externas e intermediárias. O efeito das oscilações térmicas e a redução dos parâmetros por intemperismo são exemplos de causas internas. As mudanças naturais na inclinação das camadas e mudanças na geometria do sistema estão dentre as causas externas. Enquanto que a erosão subterrânea (piping) e o rebaixamento rápido de aquíferos freáticos são considerados causas intermediárias.

Ao analisar genericamente os acidentes geológicos urbanos induzidos por perdas reais de sistemas de abastecimento de água podemos identificar esses vazamentos como agentes efetivos preparatórios que causam a pré-saturação do meio e, aliados a agentes predisponentes e efetivos imediatos, por consequência de áreas com alta declividade que são atingidas por chuvas intensas que acabam por provocar acidentes.

A USGS (2004) divide as causas de deslizamentos em geológicas, morfológicas e antrópicas. Dentre estes, a saturação de encostas pela água é considerada a principal causa de deslizamentos. Nas causas antrópicas estão incluídas: desmatamento, irrigação, mineração, vibrações artificiais e vazamentos da rede de abastecimento de água.

Nogueira Jr. e Marques (1998) destacam que a ocorrência de vazamentos de qualquer natureza podem atacar diretamente a fundação, ou alterar o equilíbrio físico-químico do maciço solo/rocha. Mesmo o vazamento de água bruta ou tratada pode promover a saturação dos materiais da fundação, modificando seu comportamento geotécnico. 


\subsection{Estrutura dos sistemas de abastecimento de água}

A água constitui-se de um elemento essencial para a sobrevivência das espécies. Sendo assim, a sociedade se desenvolveu de formar a manter este elemento sempre acessível.

Um sistema de abastecimento de água é o conjunto de obras, equipamentos e serviços voltados para o suprimento de água a comunidades, para fins de consumo doméstico, industrial e público (Azevedo Neto, 1998).

Este sistema constitui-se basicamente da captação de água de algum manancial, do seu tratamento e posterior distribuição por gravidade aos consumidores através de reservatórios em zonas mais baixas ou através de bombeamento para zonas mais altas. A Figura 1 ilustra a configuração geral de um sistema de abastecimento de água.

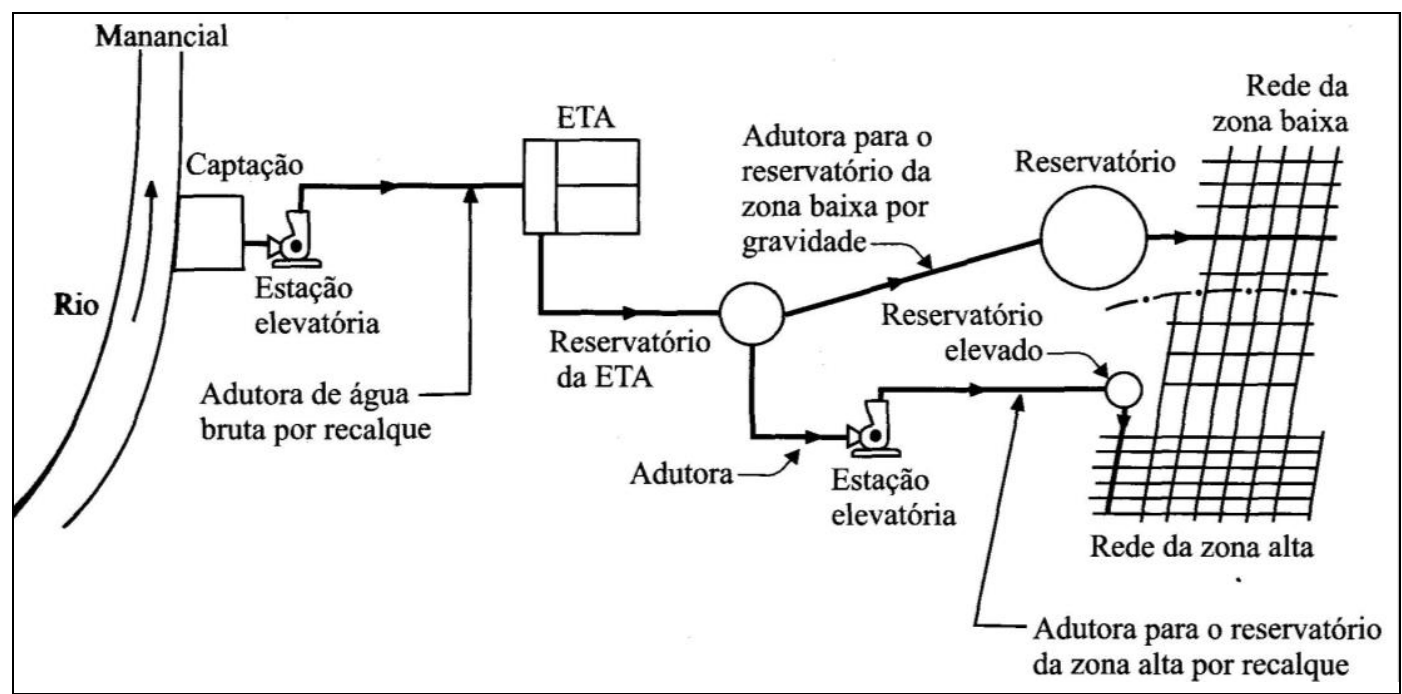

Figura 1. Configuração geral de um sistema de abastecimento de água (Orsini,1996).

De acordo com Tsutiya (2006), um sistema de abastecimento de água, é formado pelas seguintes partes:

- Manancial: é o corpo de água superficial ou subterrâneo, de onde é retirada a água para o abastecimento. Deve fornecer vazão suficiente para atender a demanda de água no período de projeto, e a qualidade dessa água deve ser adequada sob o ponto de vista sanitário.

- Captação: conjunto de estruturas e dispositivos, construídos ou montados junto ao manancial, para a retirada da água destinada ao sistema de abastecimento.

- Estação elevatória: conjunto de obras e equipamentos destinados a recalcar a água para a unidade seguinte. Em sistemas de abastecimento de água, geralmente há várias estações elevatórias, tanto para o recalque de água bruta, como para o recalque de 
água tratada. Também é comum a estação elevatória tipo "booster", que se destina a aumentar a pressão e/ou vazão em adutoras ou redes de distribuição de água.

- Adutora: canalização que se destina conduzir água entre as unidades que precedem a rede de distribuição. Não distribuem água aos consumidores.

- Estação de tratamento de água: conjunto de unidades destinado a tratar a água de modo a adequar as suas características aos padrões de potabilidade.

- Reservatório: é o elemento do sistema de distribuição de água destinado a regularizar as variações entre as vazões de adução e de distribuição e condicionar as pressões na rede de distribuição.

- Rede de distribuição: parte do sistema de abastecimento de água formada de tubulações e órgãos acessórios, destinada a colocar água potável a disposição dos consumidores, de forma contínua, em quantidade e pressão recomendada.

As redes de distribuição correspondem à parte mais onerosa de um sistema de abastecimento de água (Kleiner e Rajani, 2001; Araújo, 2005). Estas redes estão condicionadas a fatores ambientais e operacionais que podem induzir a sua deterioração que culminam no aumento de custos operacionais e de manutenção, a ocorrência de perdas de água, a redução na qualidade da própria água e dos serviços (em função do decréscimo da capacidade hidráulica da rede).

\subsubsection{Controle de Perdas}

O Brasil possui um alto índice de atendimento de água, porém uma grande parcela dessa água que é tratada não chega às torneiras em função de perdas ao longo do sistema de distribuição. Estima-se que em média $40 \%$ do total de água tratada no Brasil é desperdiçada principalmente através de vazamentos (SNIS, 2009).

As perdas de água em sistemas de abastecimento correspondem à diferença entre o volume de água fornecido (produzido ou importado) ao sistema e consumo autorizado. Conceitualmente as perdas são avaliadas sob os aspectos físico e econômico e, sendo assim, são dividas em perdas reais e perdas aparentes.

O conceito de "perdas reais" representa o volume de água que é tratado, porém não chega ao consumidor final, em função de vazamentos diversos. Esta parcela é denominada perda real, pois representa o volume de água efetivamente perdido ao longo do sistema de abastecimento. Já o conceito de "perdas aparentes" são decorrentes de imprecisão de medição, 
fraudes, ligações clandestinas e falhas no sistema de cadastro da companhia, ou seja, corresponde ao volume de água que contabiliza os tipos de imprecisões associadas às medições de água produzida e consumida, e o consumo não autorizado (PROSAB, 2009).

Segundo a International Water Association, IWA (2002), as perdas em Sistemas de Abastecimento de Água (SAAs) tornaram-se, neste século, a principal preocupação das companhias de saneamento, não só do Brasil, mas no mundo todo.

A redução das perdas físicas permite diminuir os custos de produção, mediante redução do consumo de energia, de produtos químicos, entre outros, e utilizar as instalações existentes para aumentar a quantidade oferecida, sem expansão do sistema produtor, tornando-se, portanto, ponto de grande preocupação por parte das companhias, principalmente em cenário de escassez hídrica.

\subsubsection{Condicionantes do rompimento de tubulações de água}

As causas dos rompimentos em tubulações têm sido identificadas por diversos autores (Morris, 1967; Shamir e Howard, 1979; Goulter e Kazemi, 1988). Apesar de vários fatores terem sido reportados como causas de quebras, Morris (1967) enfatiza que a causa de uma quebra numa tubulação nem sempre pode ser identificada, havendo geralmente uma combinação de fatores.

Sarzedas (2009) afirma que a idade da infraestrutura dos sistemas de abastecimento de água, aliada ao estresse contínuo desses sistemas pelas condições ambientais e operacionais a que são submetidos, têm levado a sua deterioração.

As mais importantes variáveis que descrevem a deterioração estrutural das tubulações de um sistema de abastecimento de água foram agrupadas em quatro categorias por Rostum (2000):

- Físicas ou estruturais;

- Ambientais ou externas;

- Hidráulicas ou internas;

- De manutenção.

\subsubsection{Modelagem hidráulica de Sistemas de Abastecimento de Água}

A modelagem hidráulica de sistemas de abastecimento de água permite executar simulações estáticas ou dinâmicas do comportamento hidráulico e de qualidade da água, 
através da representação de seus componentes. Desta forma, softwares que permitem realizar essa modelagem conseguem obter valores de vazão em cada trecho da tubulação, valor de pressão em cada nó ou concentração de espécies químicas ao longo da rede durante o período de simulação (Rossman, 2000).

Para elaborar um modelo de sistema de abastecimento de água, são utilizadas as seguintes informações fornecidas pela companhia de saneamento:

- Dados do sistema: extensão de rede, número de ligações, número de consumidores residenciais e não residenciais consumidores especiais, população;

- Dados estimados de consumo mínimo noturno;

- Vazão total disponibilizada para o setor (da campanha de medição de vazão);

- Volume médio micromedido (do histórico de dados comerciais) e;

- Pressão média do setor.

E então, através da simulação de cenários é possível analisar estratégias de gestão, contribuindo para uma melhor qualidade do sistema.

\subsection{Acidentes geológicos urbanos associados a vazamentos da rede de abastecimento de água.}

Um sinistro pode ser entendido como um episódio não esperado, cujas consequências podem variar da simples perda de alguns minutos ou até mesmo a total destruição de uma unidade industrial ou obra (IPT, 2013). Deste modo, os acidentes geológicos focados nesse estudo incluem-se nessa definição que é usualmente utilizada dentro das companhias de saneamento e, portanto neste caso, também serão utilizadas como sinônimos.

De acordo com Ribeiro (2007), os sinistros que ocorrem dentro do ciclo do saneamento básico predominam no processo de distribuição de água, sendo as principais causas desse fenômeno as falhas humanas (obras, manutenções, fraudes), falhas tecnológicas (equipamentos obsoletos, falhas em bombas e pressões elevadas na rede), falhas em processos (procedimentos inadequados, desatualizados ou inexistentes, erros em especificações técnicas) e riscos naturais (erosões, deslizamentos, enchentes, sismos).

Em Guarulhos, de acordo com Savino e Francisco (2005), em função do grande número de manutenção de vazamentos, algumas vezes não é possível evitar sinistros em imóveis como os causados por infiltrações, processos erosivos e danos estruturais. Assim, algumas medidas são tomadas a fim de evitar esses sinistros, as principais são: 
- Maior rigor para registro de empresas para a prestação de serviços terceirizados, assim como a rápida realização de procedimentos para concorrência pública;

- Verificação das condições das redes e ancoragens, através do levantamento de pressões e sondagens;

- Implantação de áreas de manobra com intuito de garantir maior agilidade no fechamento de registros em subsetores, assegurando diminuição do tempo médio de vazamento, bem como o fechamento de água em menores regiões para realização dos reparos;

- Manutenção preventiva e monitoramento com auxílio da telemetria.

Assim com citado anteriormente, este trabalho é focado na análise de acidentes geológicos urbanos que incluem os processos erosivos e movimentos de massa, desta forma serão analisados os sinistros que envolvem esse tipo de acidente.

A seguir são expostos eventos que abrangem o fenômeno estudado em nível mundial, nacional e local, ilustrando assim a problemática investigada neste trabalho.

\section{- Harrisburg, Pensilvania-Estados Unidos.}

Na cidade de Harrisburg, na capital da Pensilvania, em Dezembro de 2012 o solo, induzido por um vazamento de água colapsou e formou uma cratera de grandes dimensões, ilustrada através da Figura 2.

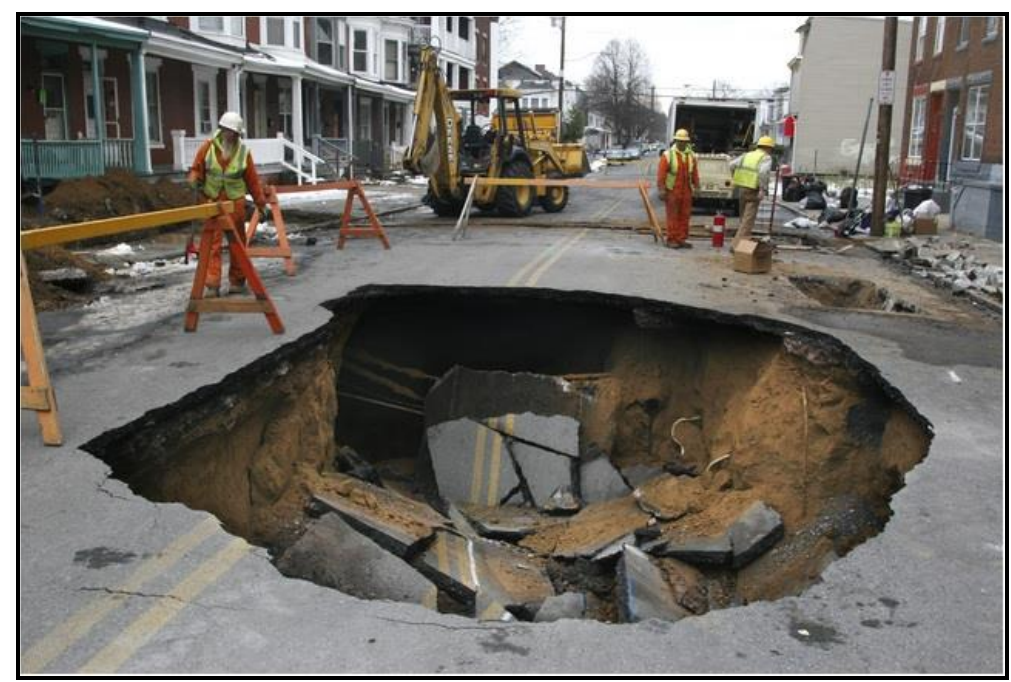

Figura 2. Enorme cratera que se formou em Harrisburg, Estados Unidos, em decorrência de um vazamento da rede de abastecimento de água. Fonte: Lancaster Online.

\section{- Lakeport, California-Estados Unidos.}


Na cidade de Lakeport, California, cerca de 160km de São Francisco nos Estados Unidos, foi constatado que o acidente que atingiu diversas moradias em Março de 2013 foi causado por um vazamento de uma tubulação de água de $50 \mathrm{~mm}$ de diâmetro. $\mathrm{O}$ acidente envolveu o afundamento do solo e inicialmente danificou a estrutura de apenas três moradias. Com o passar dos dias o movimento de massa continuou e o solo afundou mais alguns metros, aumentando os danos às estruturas da região. A Figura 3 ilustra o acidente.

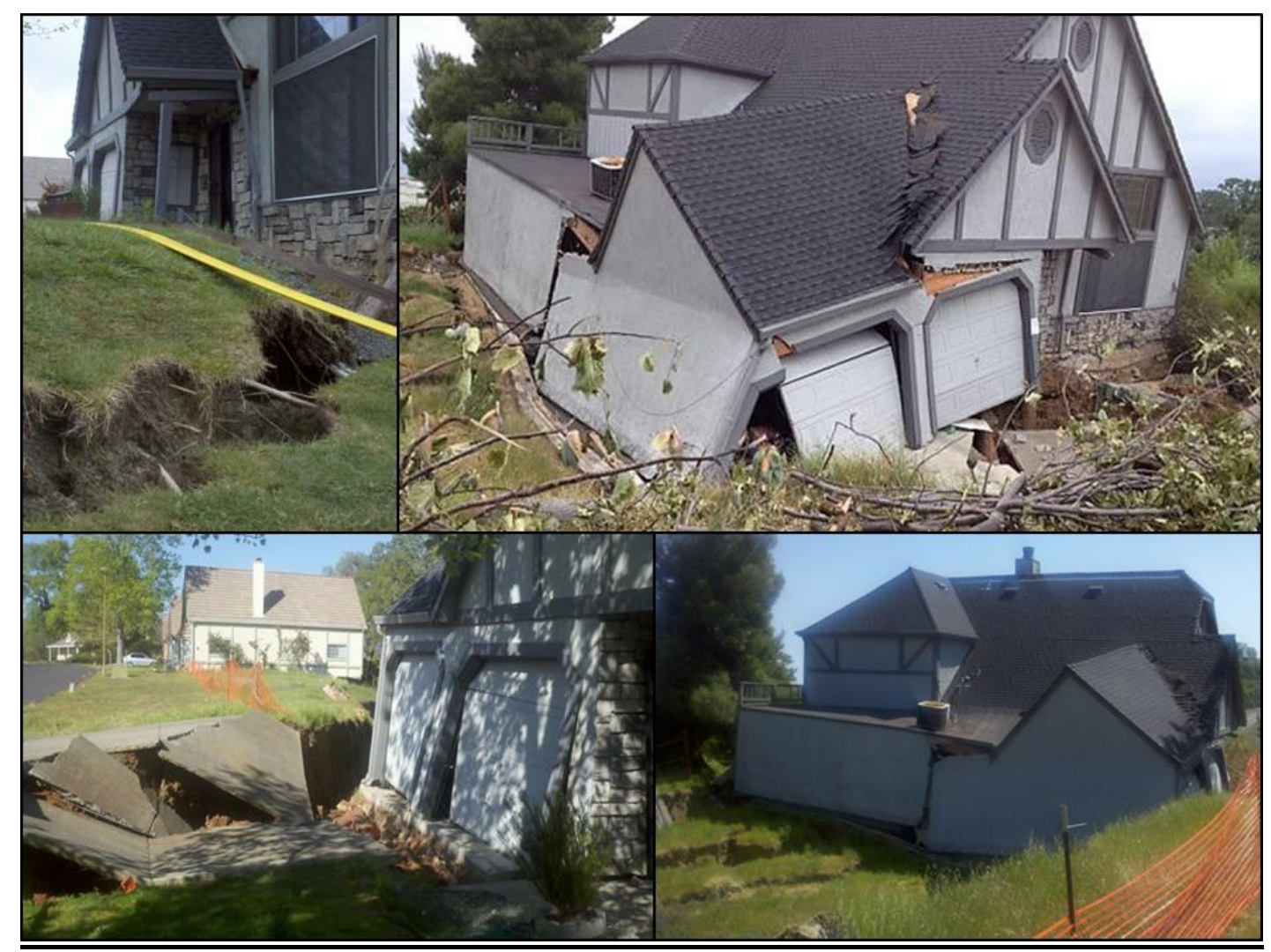

Figura 3. Grande movimentação do solo ocorrida em Lakeport, Estados Unidos, em função de vazamento de água da rede de 50mm. Fonte: ABC Local.

\section{- Rua Oscar Freire, São Paulo-Brasil.}

Semelhante ao acidente que ocorreu em Harrisburg, uma cratera se abriu no meio de uma das mais conhecidas avenidas de São Paulo, a Oscar Freire em Maio de 2013 (Figura 4). A cratera tinha em torno de dois metros de profundidade por 1,5 metro de diâmetro e segundo informações da Companhia de Saneamento Básico do Estado de São Paulo (Sabesp) um anel da junta de uma rede antiga rachou, provocando um pequeno vazamento que contribuiu para a ocorrência do acidente. 


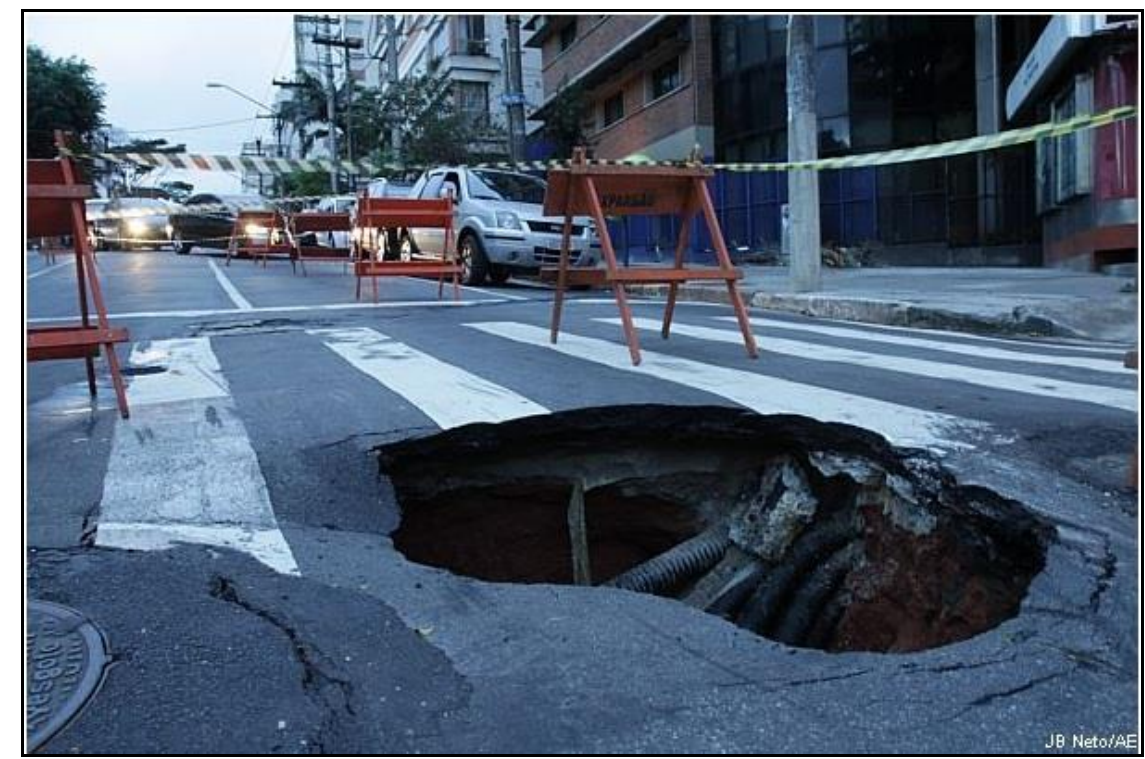

Figura 4. Cratera encontrada na Rua Oscar Freire, São Paulo. Em função de vazamento da rede de abastecimento de água. Fonte: O Estado de São Paulo Online

\section{- Guarulhos, São Paulo-Brasil.}

Os casos aqui descritos referentes ao Município de Guarulhos foram retirados de Processos de sinistros abertos dentro do SAAE para ressarcimento de danos causados aos cidadãos.

\section{- Rua Maria Conceicão, Ponte Grande.}

O acidente aconteceu no ano de 2011 no bairro da Ponte Grande, bairro residencial do extremo sudoeste de Guarulhos e atingiu quatro imóveis (Figura 5). Pode-se notar a movimentação do solo pelas enormes fissuras que surgiram nas residências. 


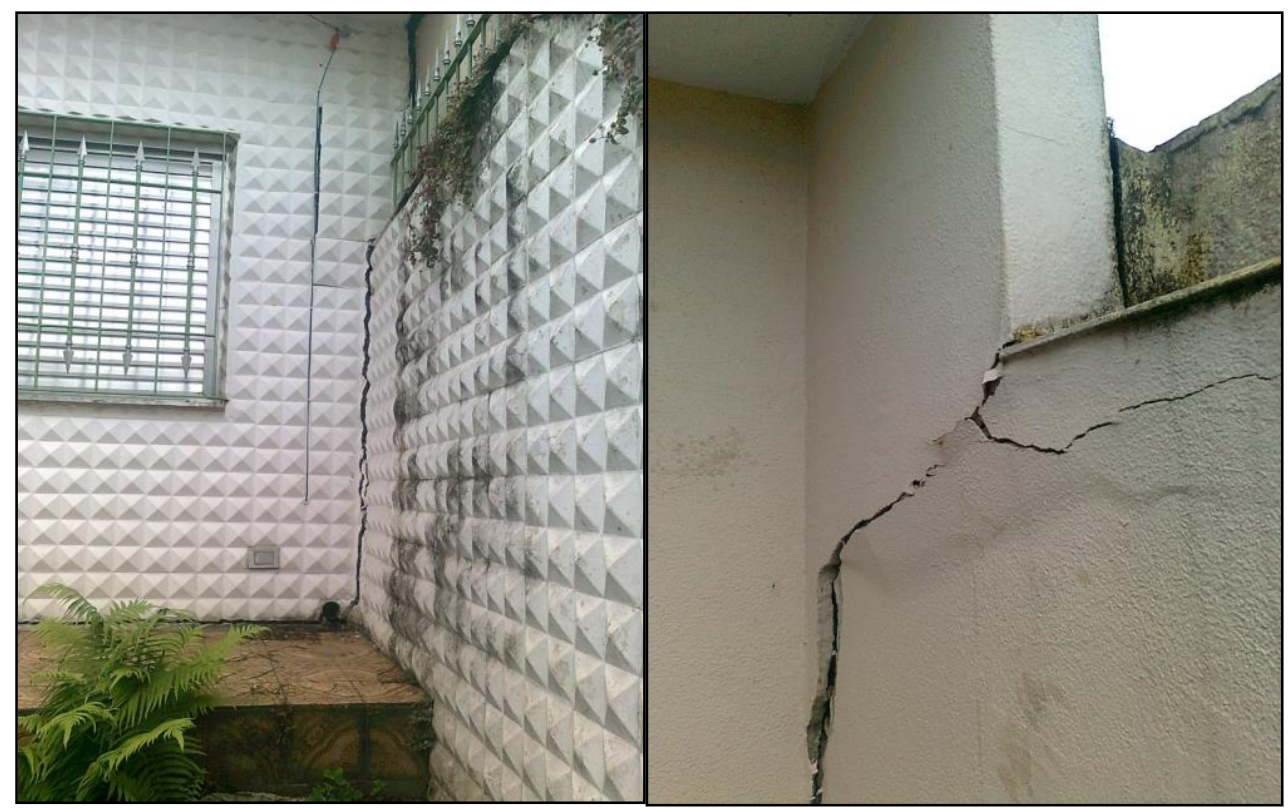

Figura 5. Fissuras que indicam a movimentação do solo em residências da Ponte Grande, Guarulhos. Fonte: SAAE Guarulhos

\section{- Rua 110, Parque Continental.}

Este acidente comprometeu dois imóveis no Parque Continental, a Figura 6 mostra o local da ocorrência de vazamento na rua e grande trinca na base da escada, que indica o movimento do solo. Andrade (1999) considerou o Parque Continental uma área especialmente problemática em relação a processos erosivos. Oliveira et al (2009) afirma que o bairro está entre as ocupações com maiores incidências de risco a escorregamentos.

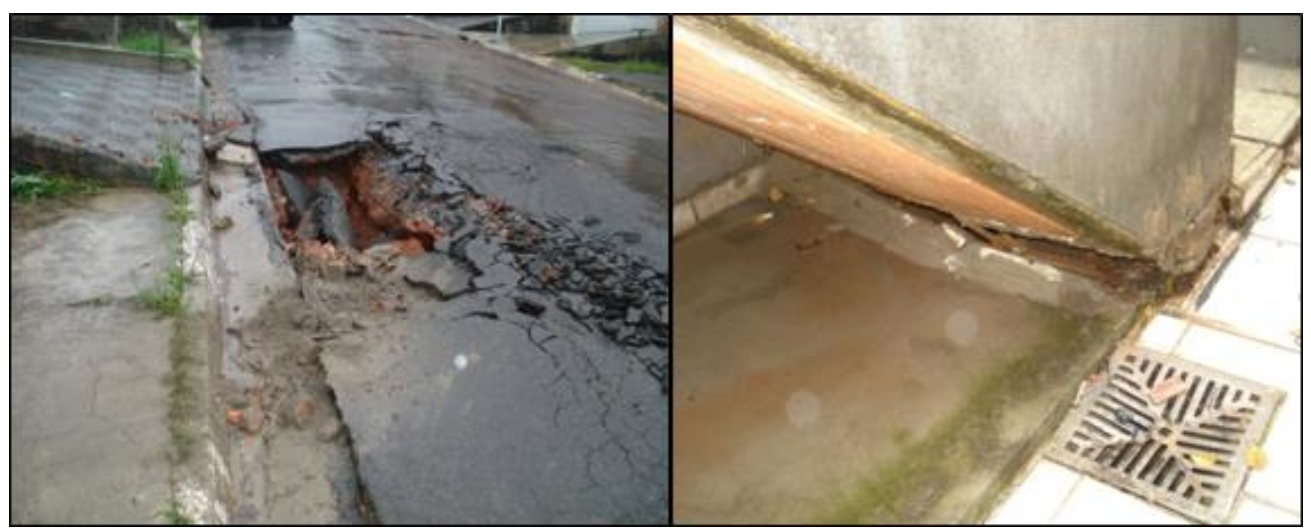

Figura 6. Local do rompimento da rede de abastecimento de água e comprometimento de imóvel próximo. Fonte: SAAE Guarulhos

\section{- Rua Margarida, Recreio de São Jorge.}

O bairro do Recreio de São Jorge é reconhecidamente problemático quanto ao risco de escorregamentos (GOMES, 2008; UZAN, 2008) aliado ao fato da idade da tubulação de água 
existente ser de mais de 20 anos, provocou um acidente que comprometeu dois imóveis em Maio de 2013 (Figura 7).

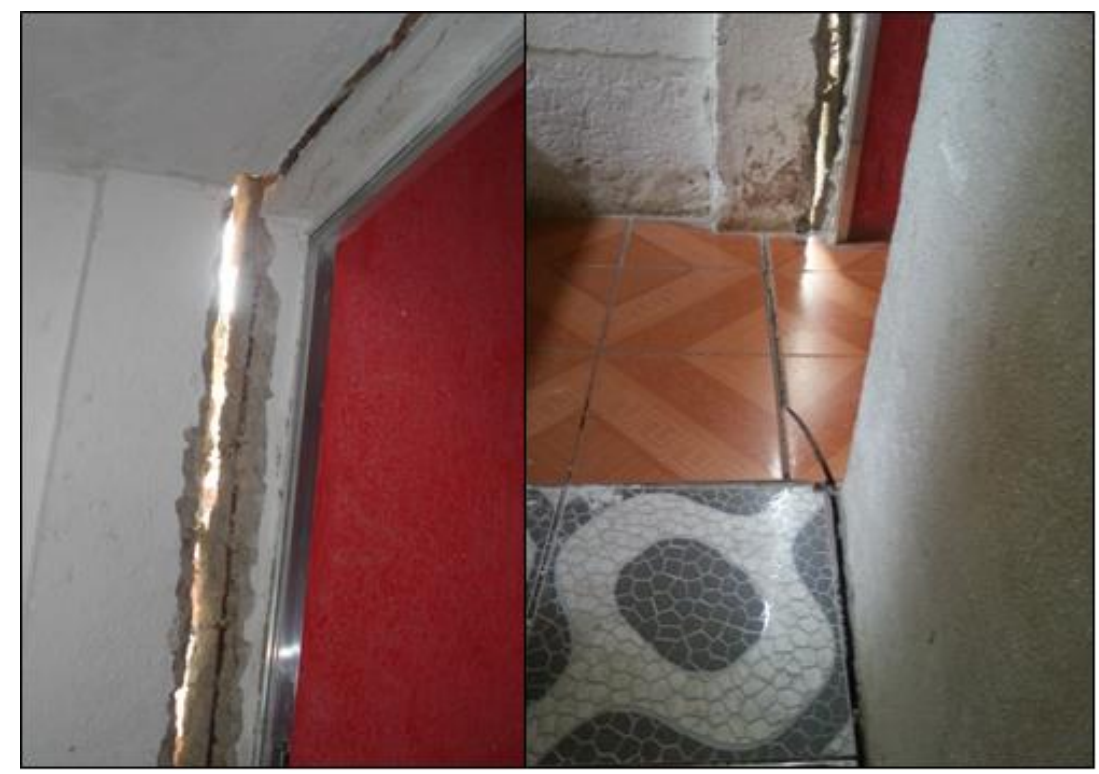

Figura 7. Movimentação do solo em imóvel no Recreio São Jorge, Guarulhos. Fonte: SAAE Guarulhos 


\section{VULNERABILIDADE AMBIENTAL E NATURAL DO MUNICÍPIO DE GUARULHOS (SP)}

\subsection{Introdução}

O aumento demográfico e o desenvolvimento socioeconômico induzem a pressão sobre o meio e o que se percebe é o aumento da ocupação de áreas geograficamente desfavoráveis, sem respeitar as características físicas do local, resultando em processos que alteram a dinâmica do solo e culminam em acidentes geológicos.

O crescimento do Município de Guarulhos, SP, não foi diferente de outros municípios próximos às grandes capitais. A expansão populacional concentrou-se inicialmente nas áreas em que o preço da terra era mais acessível, principalmente próximo a áreas de proteção ambiental e com grandes declividades, como nos bairros do Cabuçu de Cima, Tanque Grande e Morro Grande, e também na porção leste do município (Cumbica, Pimentas, Presidente Dutra e Bonsucesso), regiões com menos infraestrutura e divisa com o Município de São Paulo, principalmente através da ocupação irregular (PLHIS, 2011).

Em 2004, o Plano Estratégico Municipal para Assentamentos Subnormais (PEMAS) apontou que em Guarulhos os domicílios situados em áreas de risco e de proteção ambiental somam um total de 24,5 mil domicílios, com aproximadamente 95 mil habitantes instalados, sendo que mais de $80 \%$ destes estão localizados em área de risco (principalmente propensos à inundação ou desabamento).

Desta forma, o Município de Guarulhos apresenta alta probabilidade de ocorrência de acidentes geológicos decorrentes de escorregamentos, em razão de uma combinação de fatores: como o elevado número de áreas de risco, a alta concentração populacional nestas áreas e um alto grau de vulnerabilidade da ocupação existente (Gomes, 2008).

Assim, toda ação que modifique o estado natural do meio pode resultar, de acordo com as características do local associadas à intensidade desta ação, numa grandeza de efeitos adversos, o que pode ser denominada vulnerabilidade.

O fundamento de vulnerabilidade tratado neste trabalho advém do estudo publicado pelo Ministério do Meio Ambiente (BRASIL, 2007), que define o conceito como sendo a resposta do meio a partir de uma determinada perturbação, através de características intrínsecas à área de estudo. Desta forma, cada fração de território tem uma condição específica que, dependendo do tipo e magnitude do evento induzido, resulta numa grandeza de efeitos adversos, denominada vulnerabilidade. Esta mesma publicação cita que para o 
estudo de deslizamentos a conceituação de vulnerabilidade utilizada pela ONU (2004) é considerada mais conveniente, a qual define o termo como sendo a associação de processos e condições decorrentes de fatores físicos, sociais, econômicos e ambientais, os quais indicam o quanto uma comunidade ou elemento em risco estão suscetíveis ao impacto dos eventos perigosos.

Assim, são definidos dois tipos de vulnerabilidade. A vulnerabilidade natural (VN), a qual mostra a predisposição do ambiente frente a fatores ambientais, como geologia, geomorfologia, estabilidade em relação à morfogênese e à pedogênese (Grigio, 2003). E a vulnerabilidade ambiental (VA), definida como qualquer suscetibilidade de um ambiente a um impacto potencial provocado por um uso antrópico qualquer (Tagliani, 2003), como, por exemplo a erosão do solo, perda de biodiversidade ou assoreamento.

Através dos mapas de vulnerabilidade é possível contribuir para o planejamento do território através da ocupação racional dos espaços, prevenindo danos oriundos de processos geológicos inerentes à composição do meio físico. Pesquisas relacionadas à vulnerabilidade dos ambientes são de fundamental importância para o planejamento ambiental. A identificação dos ambientes naturais e das suas vulnerabilidades proporcionam uma melhor definição das diretrizes e ações a serem implementadas no espaço físico-territorial, servindo de base para o zoneamento e fornecendo subsídios à gestão do território (Spörl e Ross, 2004).

Nesse sentido, o objetivo desta pesquisa é realizar um levantamento da vulnerabilidade natural e ambiental do Município de Guarulhos, SP, de modo a contribuir para uma melhor caracterização do meio físico, a fim de que as áreas com altas vulnerabilidades sejam tratadas com maior cautela pelos tomadores de decisão.

A obtenção de dados geoambientais, através da utilização das geotecnologias em conjunto com os SIGs (sistemas de informações geográficas) tem sido de grande importância para as comunidades técnica e científica, principalmente por serem dados de grande confiabilidade, os quais podem ser utilizados nas mais diferentes aplicações práticas, assim como nas mais variadas áreas do conhecimento, auxiliando no planejamento ambiental (Grigio, 2003).

Assim, para a elaboração dos mapas de vulnerabilidade natural e ambiental, foram utilizadas técnicas de geoprocessamento, como a álgebra de mapas.

\subsection{Materiais}

\subsection{1. Área de Estudo}


O Município de Guarulhos localiza-se no setor nordeste da Região Metropolitana de São Paulo (RMSP), distando, aproximadamente, $17 \mathrm{~km}$ da capital, onde ocupa uma área de $319 \mathrm{~km}^{2}$, abrigando uma população superior a 1,2 milhões de habitantes, o que o torna o segundo Município paulista em população. Faz divisa com os municípios de Arujá (leste), Itaquaquecetuba (sudeste), Mairiporã (noroeste), Nazaré Paulista (norte), São Paulo (sul e oeste) e Santa Isabel (nordeste). Seus principais acessos rodoviários são as rodovias: Fernão Dias (BR-381), Presidente Dutra (BR-116) e Ayrton Senna da Silva (SP-70).

A altitude máxima do Município é de 1.438 m do espigão da Serra do Itaberaba (Pico do Gil) e a mínima de $660 \mathrm{~m}$ encontra-se na foz do Ribeirão Jaguari a nordeste do Município. A Figura 8 apresenta a divisão dos bairros no Município de Guarulhos.

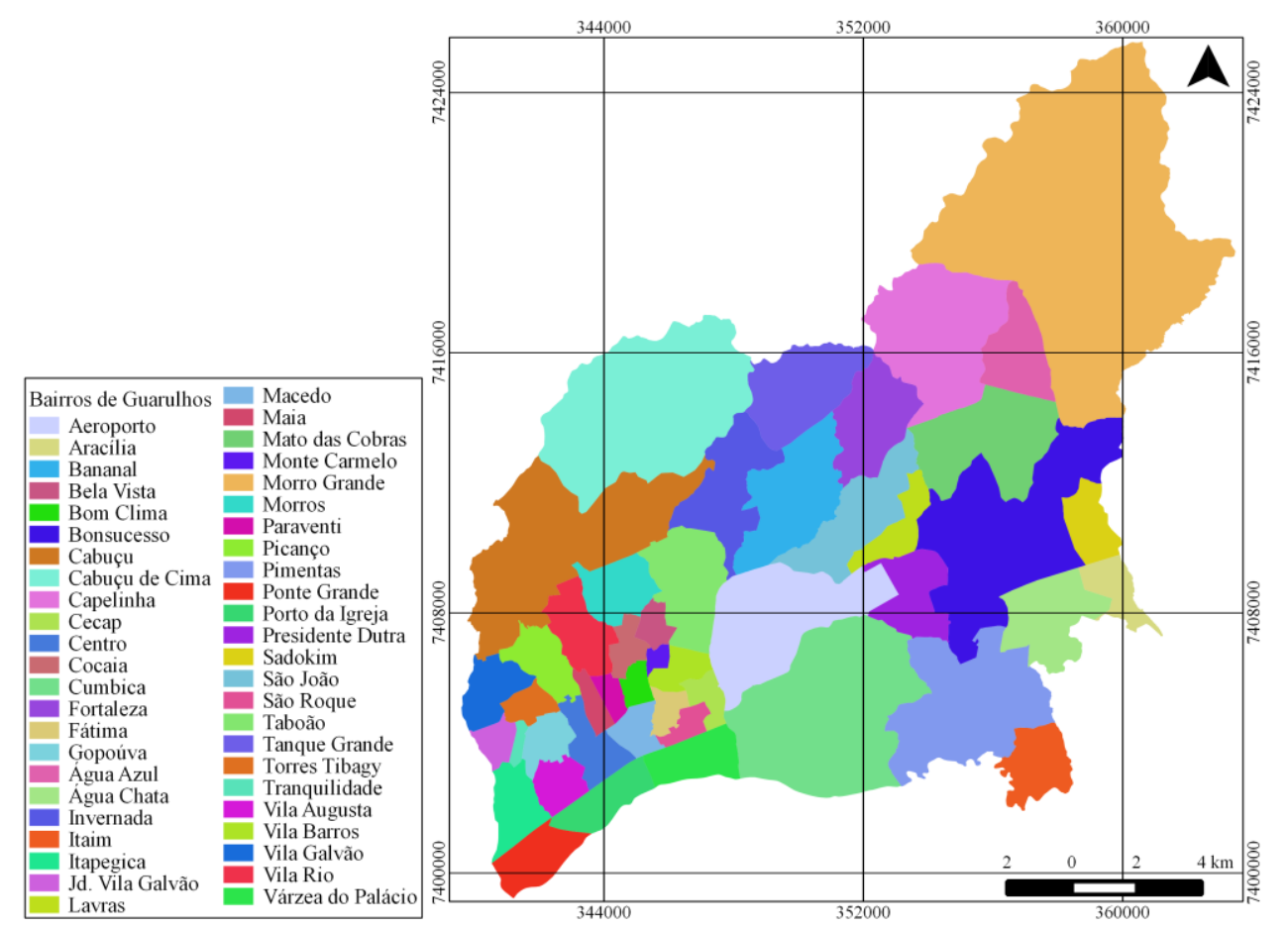

Figura 8. Município de Guarulhos e seus respetivos bairros.

\subsubsection{Dados vetoriais}

A metodologia utilizada neste trabalho utilizou como base as propostas por Grigio (2003) e Carrijo (2005), onde para a elaboração da carta de vulnerabilidade natural utilizou-se os dados de Geologia, Pedologia e Declividade e para a carta de vulnerabilidade ambiental, utilizou-se a carta de vulnerabilidade natural (gerada neste trabalho) em conjunto com os dados de uso e ocupação do solo.

Todos esses dados foram adquiridos em formato vetorial através do "Projeto Bases Geoambientais para um Sistema de Informações Ambientais do Município de Guarulhos”, 
disponibilizados gratuitamente pela Universidade de Guarulhos (Oliveira et al., 2009). Os mesmos foram ajustados na projeção UTM, datum SAD 1969, pelo fato de ser o sistema de origem da maioria dos dados utilizados.

Para a análise dos fatores, utilizaram-se os critérios estabelecidos por Tricart (1977), conforme Tabela 2. De forma prática, Tricart (1977) estabelece que a pedogênese advém da transformação específica de minerais por meio de consequências da ocupação, constituindo-se portanto um meio estável, enquanto que a morfogênese traduz a instabilidade da superfície, atuando como um fator limitante no desenvolvimento do seres vivos.

Desta forma, foram estabelecidos que fatores com pesos próximos ao valor 1,0 prevalecem cenários de pedogênese, fatores próximos ao valor 2,0 persistem um equilíbrio entre a pedogênese e a morfogênese, e valores próximos a 3,0 prevalecem a morfogênese, ou seja, representam cenários instáveis.

Tabela 2. Valores de estabilidade conforme Tricart (1977).

\begin{tabular}{ccc}
\hline Unidade & Relação pedogênese/morfogênese & Valor \\
\hline Estável & Prevalece a pedogênese & 1,0 \\
Intermediária & Equilíbrio entre pedogênese e & 2,0 \\
Instável & morfogênese & 3,0 \\
\hline
\end{tabular}

\section{- Aspectos Geológicos}

A análise da Geologia para definição de vulnerabilidades compreende as informações relativas à história da evolução geológica do ambiente onde a unidade se encontra, e as informações relativas ao grau de coesão das rochas que a compõem, uma vez que em rochas pouco coesas prevalecem os processos modificadores das formas de relevo, enquanto que nas rochas bastante coesas prevalecem os processos de formação de solos (Crepani, 2001).

O Município de Guarulhos está contido em duas grandes unidades geológicas: embasamento cristalino de idade Pré-cambriana e sedimentos Terciários e Quaternários pertencentes à Bacia de São Paulo (Figura 9).

A principal estrutura existente no município é a Falha do Rio Jaguari, transcorrente, posicionada ao centro do território, com direção SW-NE, que expressa claramente a formação do graben da Bacia de São Paulo, que indica um limite nítido entre os terrenos predominantemente cristalinos, Pré-cambrianos, que formam um horst a norte associado ao Domínio São Roque e um graben a sul associado ao Domínio Embu. 


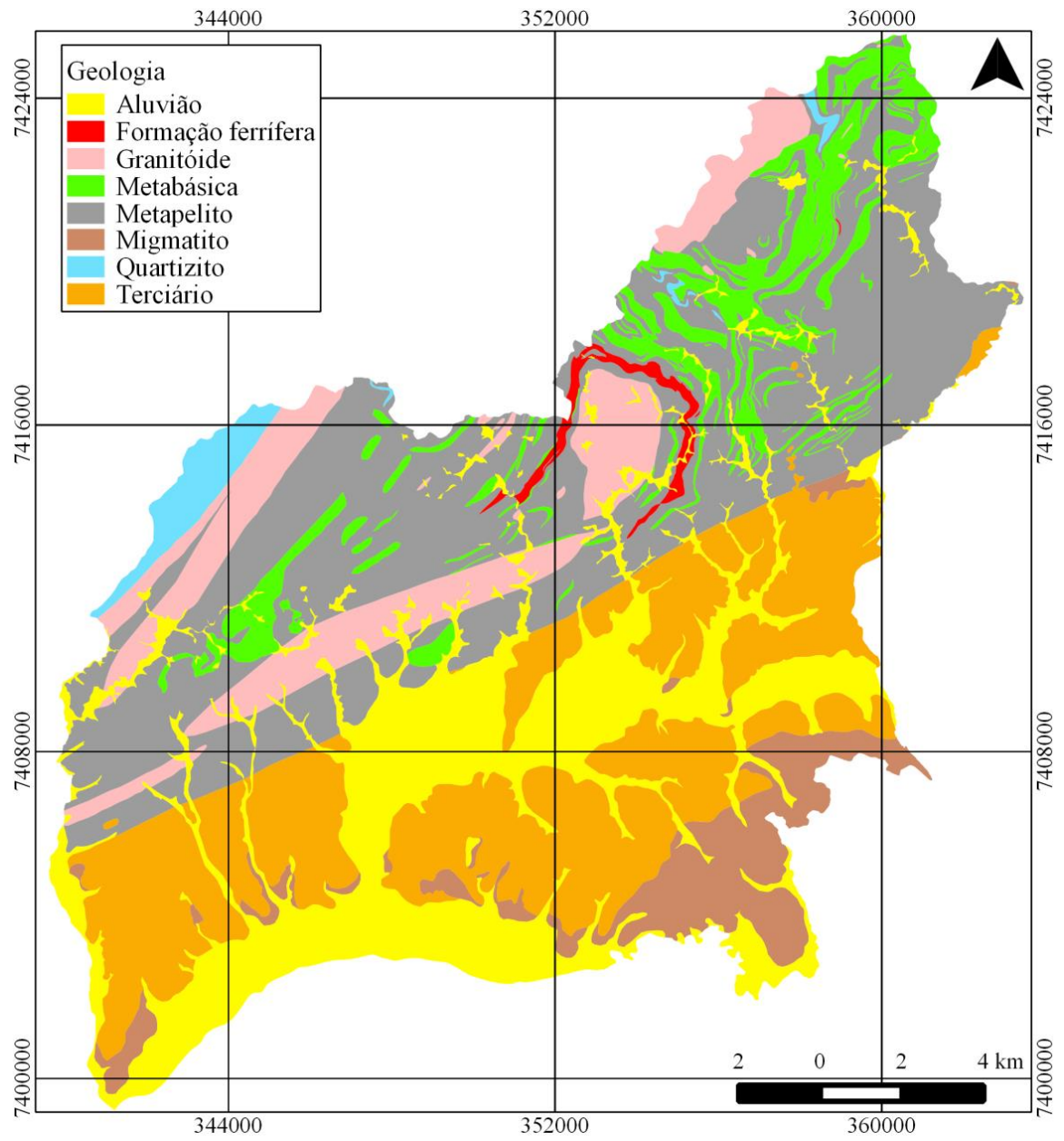

Figura 9. Mapa Geológico de Guarulhos. Reparar que há um contato abrupto entre as rochas Cenozoicas que constituem a Planície Costeira e as rochas Pré-cambrianas que suportam o relevo da Serra do Mar no município. Adaptado de: Oliveira et al, 2009.

As unidades litológicas foram determinadas através do mapa geológico produzido por Oliveira et al (2009), elaborado a partir da composição de estudos pré-existentes realizados pelos seguintes autores Coutinho (1979), Dantas (1990), Juliani (1993) e Oliveira (2005, a,b).

O desenvolvimento do trabalho de Oliveira et al (2009) incluiu também reconhecimento geológico em campo e o resultado foi a elaboração de um mapa geológico em escala 1:30.000 apresentado na Figura 9. Essas unidades foram agrupadas em razão de similaridades geotécnicas e são listadas a seguir:

- Sedimentos Quaternários: aluviões e coluviões;

- Sedimentos Terciários: sistema de leques aluviais;

- Granitoides: granitos e granito-gnaisses;

- Quartzitos: quartzitos e metarenitos;

Metassedimentar: metapelitos, metarritmitos, filitos, xistos, cálcio-silicáticas, 
marunditos;

- Metavulcânica: metabasitos, anfibolitos, anfibólio-xistos, metavulcanoclásticas, metatufitos;

- Formação ferrífera.

Assim, no território de Guarulhos predominam as rochas metassedimentares, sedimentos terciários e aluviões, perfazendo este conjunto cerca de $75 \%$ da área do município (Oliveira et al, 2009).

Para a escolha dos pesos de geologia, foram atribuídos pesos de maior valor às rochas formadas por sedimentos inconsolidados ou baixo grau de consolidação, sendo que estes apresentam pouca resistência à desagregação. Os pesos intermediários foram atribuídos às rochas metassedimentares, por apresentarem estruturas de xistosidade ou foliação metamórfica, que acabam por gerar zonas de fraqueza nessas rochas. Já os granitos, migmatitos e metavulcânicas, que apesar de rochas maciças, podem apresentar fraturamentos ou formações de blocos arredondados, receberam pesos relativamente inferiores. Os quartizitos e formações ferríferas receberam os menores pesos devido a sua alta resistência ao intemperismo.

A Tabela 3 ilustra a atribuição destes pesos.

Tabela 3. Pesos estabelecidos para as classes de Geologia.

\begin{tabular}{|c|c|c|c|}
\hline $\begin{array}{c}\text { Classificação Projeto } \\
\text { Bases }\end{array}$ & Descriçãa & $\begin{array}{c}\text { Correspondência } \\
\text { Crepani }\end{array}$ & Peso \\
\hline $\begin{array}{l}\text { Sedimentos } \\
\text { Quaternários }\end{array}$ & (aluviões e coluviões) & $\begin{array}{c}\text { Sedimentos } \\
\text { Inconsolidados: } \\
\text { Aluviões, Colúvios } \\
\text { etc. }\end{array}$ & 3,0 \\
\hline Sedimentos Terciários & $\begin{array}{c}\text { (sistema de leques aluviais) } \\
\text { (Granitos e Granito - } \\
\text { gnaisses) (Migmatitos e } \\
\text { Gnaisses - } \\
\text { migmatíticos) }\end{array}$ & Migmatitos, Gnaisses & 1,3 \\
\hline Quartzitos & (Quartzitos e Metarenitos) & $\begin{array}{l}\text { Quartzitos ou } \\
\text { metaquartzitos }\end{array}$ & 1,0 \\
\hline Metassedimentares & $\begin{array}{c}\text { (Metapelitos, } \\
\text { Metarritmitos, Filitos, } \\
\text { Xistos, Cálcio-silicáticas, } \\
\text { Marunditos) }\end{array}$ & Filito, Metassiltito & 2,1 \\
\hline Metavulcânicas & $\begin{array}{l}\text { (Metabasitos, Anfibolitos, } \\
\text { Anfibólio-xistos, } \\
\text { Metavulcanoclásticas, } \\
\text { Metatufitos) }\end{array}$ & - & 1,5 \\
\hline
\end{tabular}




\begin{tabular}{cccc}
\hline $\begin{array}{c}\text { Classificação Projeto } \\
\text { Bases }\end{array}$ & Descrição & $\begin{array}{c}\text { Correspondência } \\
\text { Crepani }\end{array}$ & Peso \\
\hline Formação ferrífera & & - & 1,0 \\
\hline
\end{tabular}

- Aspectos Pedológicos

A Pedologia contribui para a definição de vulnerabilidade através da maturidade dos solos presentes, produto direto do balanço entre morfogênese/pedogênese, indicando claramente se prevalecem os processos erosivos da morfogênese que geram solos jovens, pouco desenvolvidos, ou se, no outro extremo, as condições de estabilidade permitem o predomínio dos processos de pedogênese gerando solos maduros, lixiviados e bem desenvolvidos (Crepani, 2001).

Em Guarulhos predominam, com cerca de $60 \%$ os solos do tipo Cambissolo e Latossolo. Também aparecem em menor proporção os Argissolos (14,50\%), Gleissolos $(12,50 \%)$, Organossolos (7,30\%), Mineração (1,1\%), Neossolos flúvicos (1,00\%), Neossolos litólicos $(0,65 \%)$ e Plintossolos $(0,05 \%)$ (Figura 10). Esses solos são caracterizados de maneira geral como argilosos, de baixa fertilidade, ácidos a excessivamente ácidos e com profundidades variadas. Quanto à plasticidade, são enquadrados como fracos a mediamente plásticos (OLIVEIRA et al, 2009).

O mapa pedológico, apresentado na Figura 10, ilustra o aparecimento desses solos em Guarulhos. Os solos presentes no território de Guarulhos representam as características geológicas e geomorfológicas da região. Andrade (1999) destacou a forte associação entre os parâmetros naturais, como o clima e o ecossistema original. Assim, segundo o trabalho de Oliveira et al (2009), os Gleissolos associam-se a sedimentos quaternários e predominam em relevos de planície, os Argissolos relacionam-se a sedimentos terciários e relevo colinoso e os Latossolos e Cambissolos associam-se ao complexo cristalino e terrenos amorreados. 


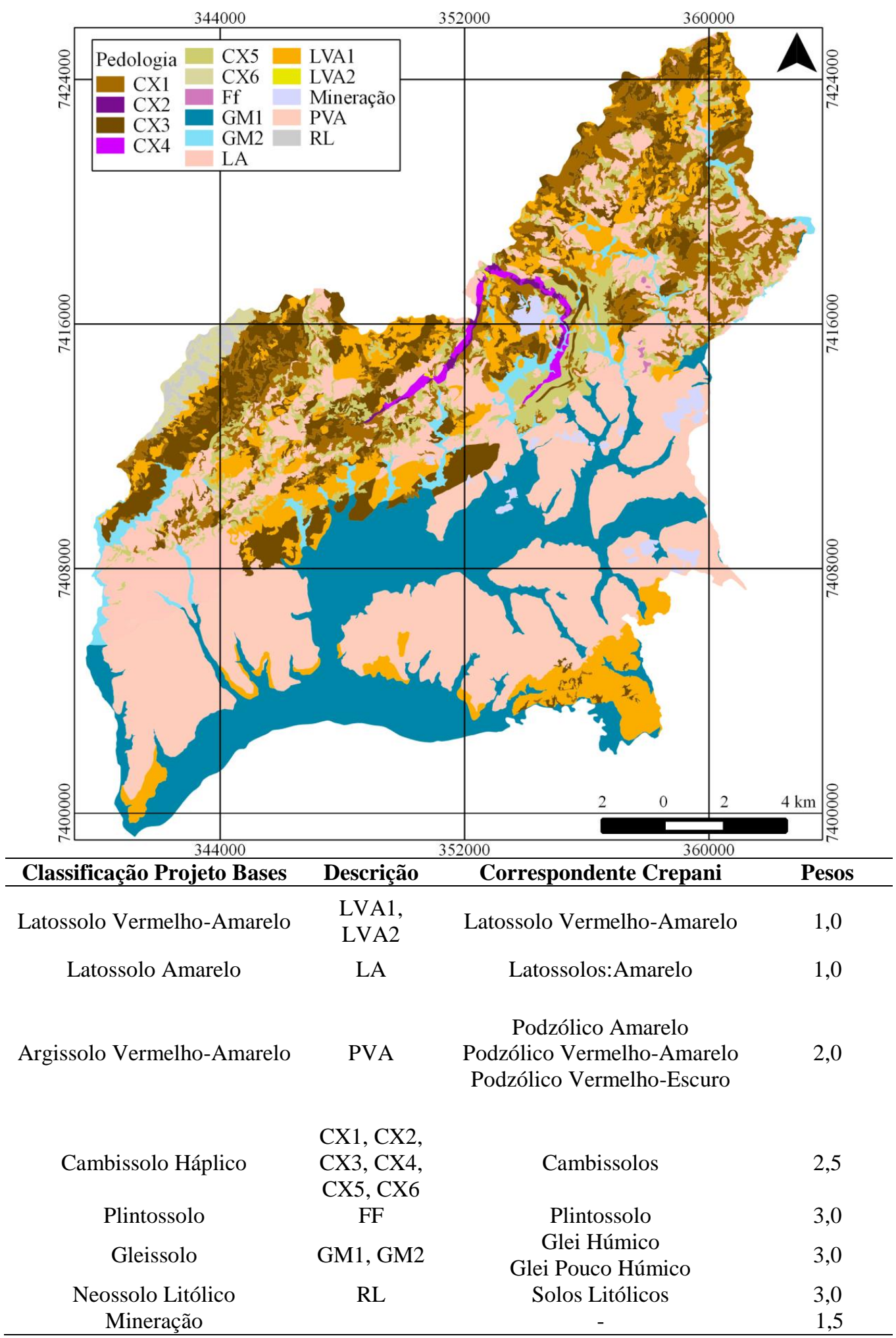

Figura 10. Mapa Pedológico de Guarulhos com os pessoas adotados na álgebra de mapas. A planície costeira possui solos mais homogeneamente distribuídos do que a região serrana. Adaptado de: Oliveira et al, 2009.

Com relação aos pesos estabelecidos, tem-se que para os solos mais maduros, ou seja, mais estáveis, atribuiu-se pesos menores. Os valores intermediários de pesos foram 
facultados aos solos Podzólicos, que apresentam profundidade menor, sendo menos estáveis. Estes são representados no caso pelos Argissolos e Cambissolos.

Os solos mais vulneráveis são representados por solos jovens e pouco desenvolvidos, em fase de desenvolvimento a partir dos materiais de origem recentemente depositados. Estes solos são representados no Município de Guarulhos através dos Gleissolos e Neossolos. A classe de mineração foi entendida como quase ausência do solo e exposição da rocha, sendo atribuído um peso próximo à estabilidade.

- Declividade

Através da análise do mapa geomorfológico resultante do projeto, apresentado na Figura 11, pode-se observar uma nítida divisão de dois compartimentos geomorfológicos, com características bem definidas:

- Compartimento norte: predominância de montanhas e morros, com altitudes variando de 850 até mais de $1.200 \mathrm{~m}$, declividades e amplitudes elevadas, constituído principalmente de rochas cristalinas.

- Compartimento sul: marcado pela presença de planícies e de colinas, com alguns morrotes, com altitudes que variam de 670 a $850 \mathrm{~m}$, amplitudes e declividades baixas. Este tipo de relevo relaciona-se à cobertura terciária e quartenária da Bacia Sedimentar São Paulo.

Desta forma, Oliveira et al (2009) concluíram que no compartimento norte predomina a influência de processos geomorfológicos, enquanto que no compartimento sul predomina a influência de propriedades intrínsecas das litologias.

Neste trabalho utilizou-se o mapa de declividade proveniente também do estudo desenvolvido por Oliveira et al (2009) para analisar a influência da geomorfologia nas vulnerabilidades. 


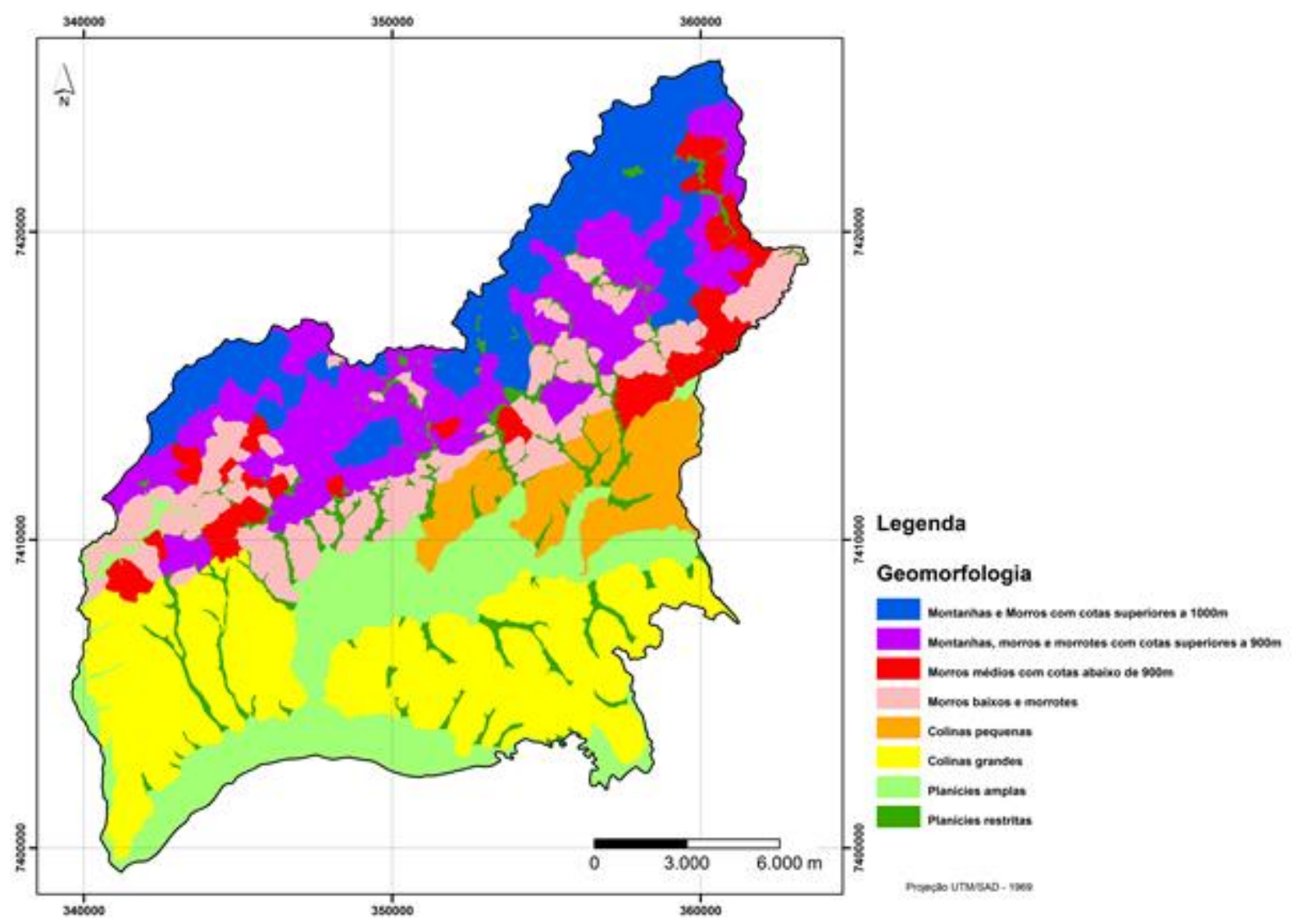

Figura 11. Mapa geomofológico de Guarulhos. Nota-se a divisão de dois compartimentos, evidenciados pela presença de montanhas e morros ao norte e planícies e colinas ao sul. Adaptado de: Oliveira et al, 2009

O substrato geológico e a cobertura pedológica apresentam grande influência, especialmente, nos escorregamentos que ocorrem em situações e causas naturais. No entanto, a declividade da encosta é o fator preponderante na grande maioria dos processos de movimentação de massa, especialmente quando se tratam de solos com baixa coesão. Quando se associa, ao substrato geológico e à cobertura pedológica, a influência antrópica, mesmo em condições de substrato e cobertura de solo favoráveis, os escorregamentos são mais dependentes ainda do fator declividade (Oliveira et al,2009).

A declividade do Município de Guarulhos é apresentada na Figura 12.

A declividade contribui no processo de vulnerabilidade através da transformação de energia potencial em energia cinética responsável pelo transporte de materiais que esculpem as formas de relevo (Crepani, 2001). Desta forma, altas declividades receberam pesos altos e declividades baixas, os pesos mais baixos. Os pesos atribuídos para cada classe de declividade são apresentados na Tabela 4. 


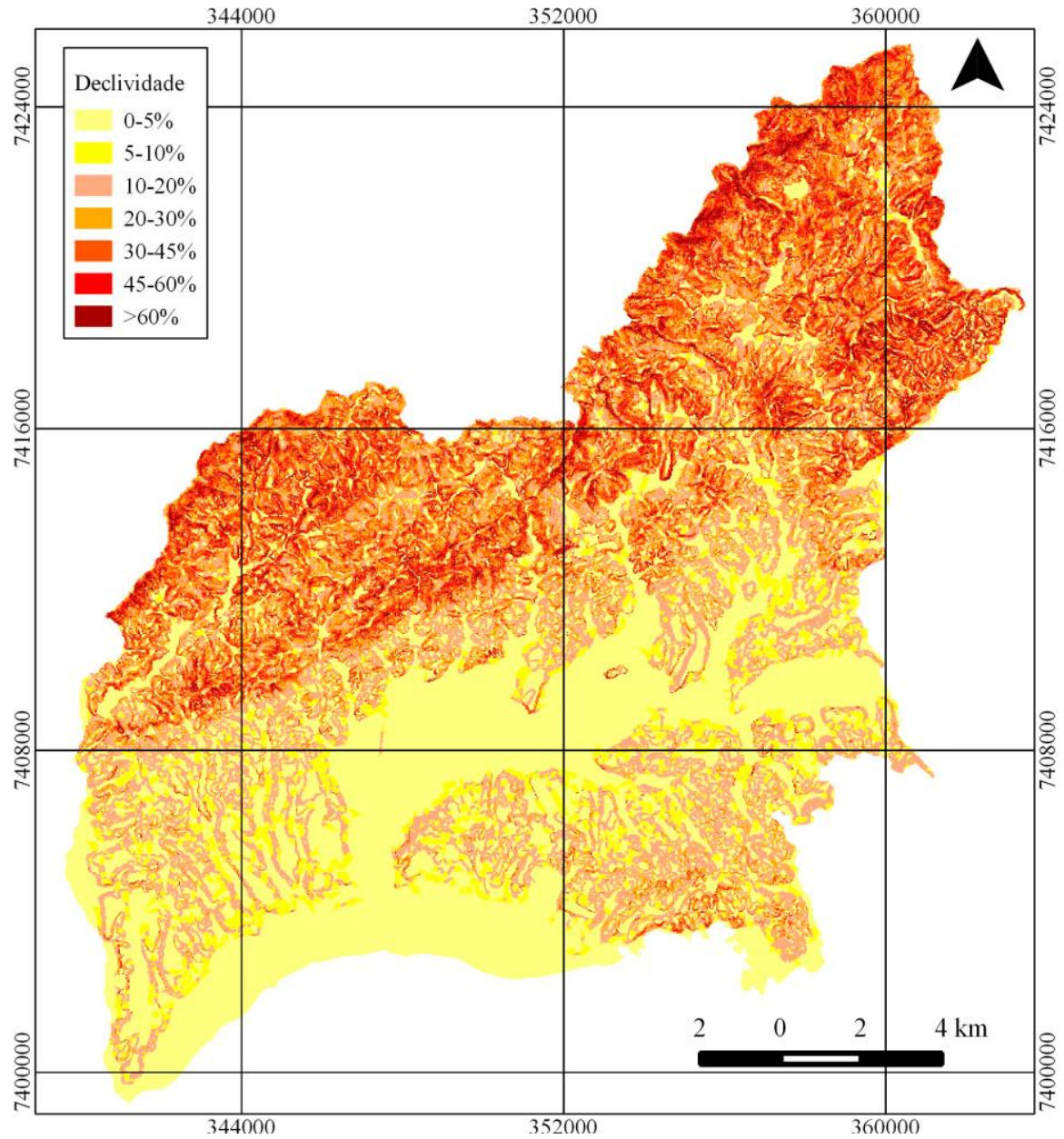

Figura 12. Mapa de declividade de Guarulhos As altas declividades se concentram na região serrana ao norte. Adaptado de: Oliveira et al, 2009.

Tabela 4 Pesos atribuídos para as classes de declividade.

\begin{tabular}{ccc}
\hline Classificação Projeto Bases & $\begin{array}{c}\text { Correspondente } \\
\text { Crepani }\end{array}$ & Pesos \\
\hline $0-5 \%$ & $<2 \% / 2-6$ & 1,3 \\
$5-10 \%$ & $2-6 / 6-20$ & 1,7 \\
$10-20 \%$ & $6-20$ & 2 \\
$20-30 \%$ & $20-50$ & 2,5 \\
$30-45 \%$ & $20-50$ & 2,8 \\
$45-60 \%$ & $>50 \%$ & 3,0 \\
$>60 \%$ & $>50 \%$ & 3,0 \\
\hline
\end{tabular}

- Uso do Solo

Ao observar o mapa de uso do solo no Município de Guarulhos consegue-se identificar basicamente a seguinte divisão: o aparecimento de áreas urbanas a sul, áreas com cobertura vegetal a norte e a área correspondente ao aeroporto no centro do território. 
O mapeamento do uso do solo foi realizado através do trabalho de Oliveira et al (2009) e foi elaborado a partir de imagens do satélite Ikonos, datadas do ano de 2007, onde foi possível a determinação de 9 classes e 26 subclasses, ilustradas a partir da Figura 13.

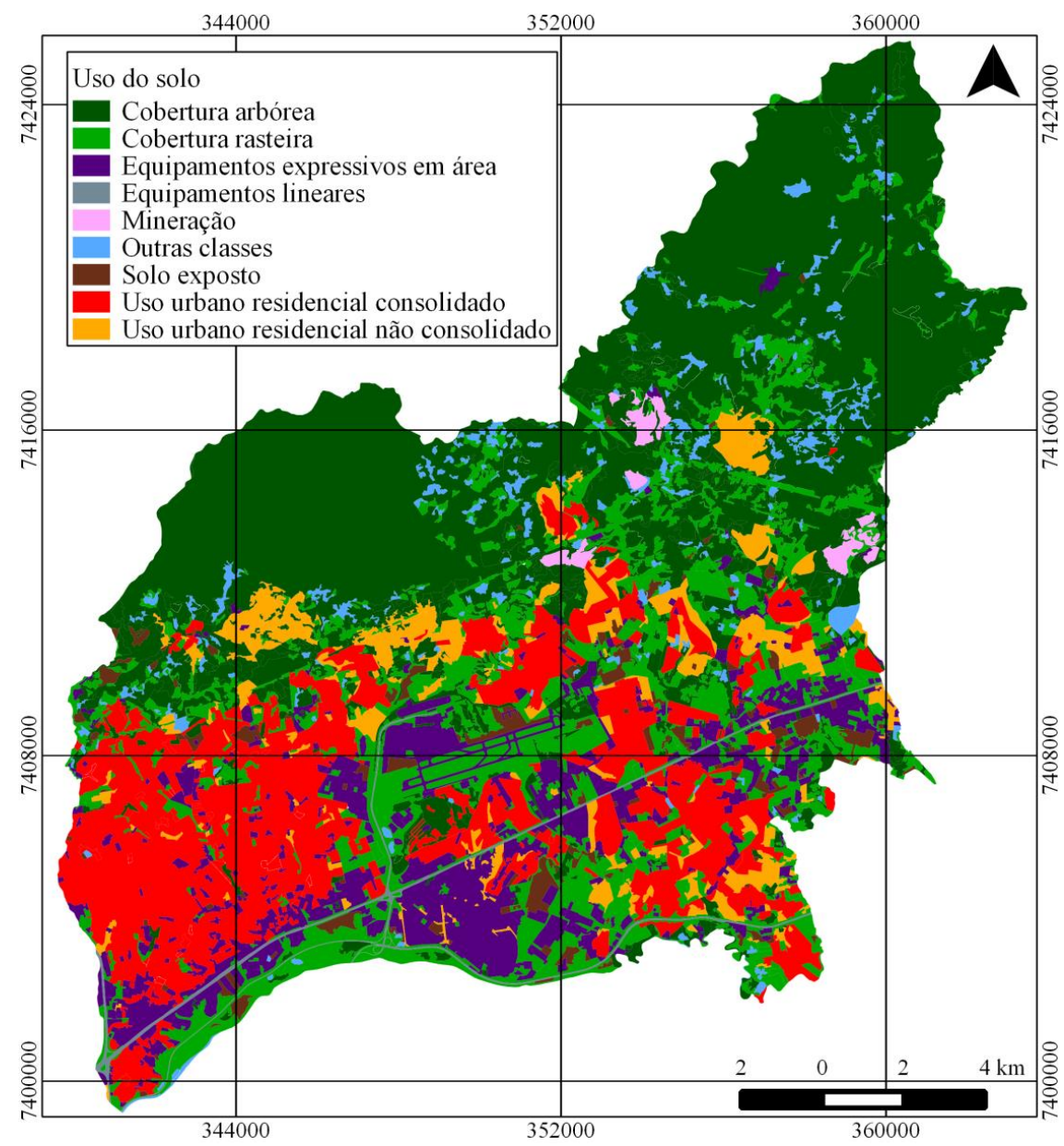

Figura 13. Mapa de Uso do Solo de Guarulhos. A região serrana concentra os remanescentes de Mata Atlântica do Município enquanto a trama urbana abriga o aeroporto de Guarulhos, grande mola propulsora do desenvolvimento urbano do município. Adaptado de: Oliveira et al, 2009.

Através do mapeamento foi possível identificar áreas urbanas em cerca de $25 \%$ do território, áreas naturais em quase $60 \%$ do território, representadas principalmente pelo Parque Estadual da Cantareira (no bairro do Cabuçu de Cima, a noroeste) e no bairro de Morro Grande (a nordeste do Município), onde aparecem propriedades rurais. Também puderam ser identificadas áreas de mineração (bairros do Capelinha, Jardim Fortaleza e Bonsucesso), manchas de solo exposto (aterro e corte) e áreas que aparecem de maneira pontual (cemitérios, aterro sanitário, presídios, etc.).

A vegetação original do território, segundo Andrade (1999), era composta por dois tipos básicos: a Floresta Ombrófila Densa, ocupando a região de morros, e vegetação de cerrado ocupando o relevo de colinas, a qual já não possui mais remanescente. 
Em Guarulhos percebe-se claramente a expansão da mancha urbana para as áreas ao norte do Município (bairros de São João, Bonsucesso e Presidente Dutra) e a tendência de conurbação da área ao sul com a Zona Leste do Município de São Paulo (bairros Pimentas e Itaim). Nesses bairros predominam população de baixa renda e infraestrutura urbana debilitada (OLIVEIRA et al, 2009), fato que contribui para o aumento da situação de risco na região.

O critério estipulado para o mapa de uso e ocupação do solo seguiu o estudo de Grigio (2003) e teve como foco principal o grau e tipo de antropização encontrados no município (Tabela 5). Assim os pesos foram estipulados com base nas subclasses determinadas no mapa base de uso e ocupação, desenvolvido através do Projeto Bases geoambientais para um sistema de informações ambientais do Município de Guarulhos (Oliveira et al., 2009).

Tabela 5. Valores estabelecidos para cada classe de uso do solo.

\begin{tabular}{|c|c|c|}
\hline $\begin{array}{c}\text { Classes Projeto } \\
\text { Bases } \\
\end{array}$ & Subclasses & PESOS \\
\hline Cobertura arbórea & $\begin{array}{c}\text { Capoeira } \\
\text { Mata } \\
\text { Mista } \\
\text { Reflorestamento }\end{array}$ & 1 \\
\hline Cobertura rasteira & $\begin{array}{l}\text { Campo } \\
\text { Cultivo } \\
\end{array}$ & $\begin{array}{l}1.5 \\
1.3 \\
\end{array}$ \\
\hline $\begin{array}{l}\text { Uso urbano } \\
\text { residencial } \\
\text { consolidado } \\
\text { Uso urbano } \\
\text { residencial não } \\
\text { consolidado }\end{array}$ & Alta densidade, média e baixa & 3 \\
\hline $\begin{array}{l}\text { Equipamentos } \\
\text { expressivos em área }\end{array}$ & $\begin{array}{c}\text { Aeroporto } \\
\text { Cemitério } \\
\text { Estação de transm e distr de } \\
\text { energia } \\
\text { ETA } \\
\text { Fábricas e galpões } \\
\text { Presídios } \\
\text { Tanques } \\
\end{array}$ & $\begin{array}{c}2 \\
1 \\
1 \\
2.7 \\
2 \\
2 \\
2 \\
\end{array}$ \\
\hline $\begin{array}{c}\text { Equipamentos } \\
\text { lineares }\end{array}$ & Rodovia & 2.8 \\
\hline Mineração & $\begin{array}{c}\text { Pedreira } \\
\text { Porto de Areia }\end{array}$ & $\begin{array}{l}1.3 \\
1.3 \\
\end{array}$ \\
\hline Solo exposto & $\begin{array}{c}\text { Aterro } \\
\text { Corte } \\
\end{array}$ & $\begin{array}{l}1.5 \\
2.5 \\
\end{array}$ \\
\hline Outras classes & $\begin{array}{c}\text { Canal } \\
\text { Chácaras e edificações rurais } \\
\text { Reservatórios }\end{array}$ & $\begin{array}{c}1 \\
1.1 \\
1 \\
\end{array}$ \\
\hline
\end{tabular}

Com o mapa de vulnerabilidade ambiental pretende-se analisar a suscetibilidade do ambiente a pressões antrópicas, no caso os vazamentos da rede de abastecimento de água. 
Sendo assim, as classes que possuem possibilidade de ocorrência de vazamentos (áreas consolidadas) receberam o peso máximo, enquanto que os demais pesos foram estipulados levando-se em consideração a existência de rede de abastecimento nos locais e como vazamentos afetariam o entorno.

\subsubsection{Levantamento dos acidentes geológicos em Guarulhos}

Quando ocorre um vazamento da rede de abastecimento de água em Guarulhos e este afeta uma ou mais moradias, o SAAE avalia in loco os prejuízos causados para então prosseguir com o ressarcimento. O registro deste tipo de ocorrência é realizado através da abertura de processos administrativos internos que tramitam entre os setores do SAAE a fim de avaliar os danos causados aos moradores.

Assim, para avaliar as ocorrências desses eventos foi realizado o levantamento de Processos Administrativos desencadeados por cada um desses eventos. Ao todo foram levantados dezenove casos que foram utilizados para validação dos mapas gerados. Alguns casos, por terem ocorrido em período muito próximo ao levantamento, ainda não possuíam processo administrativo, porém mesmo assim foram incluídos no estudo. A Tabela 6 apresenta os acidentes que foram pesquisados.

Tabela 6. Acidentes levantados em Guarulhos, SP.

\begin{tabular}{|c|c|c|c|c|c|}
\hline & $\mathbf{N}^{\mathbf{o}}$ & Ano & Endereço & Assunto & $\begin{array}{c}\text { Observações } \\
\text { (contidas nos } \\
\text { processos) }\end{array}$ \\
\hline \multirow{3}{*}{1} & 6551 & 2010 & $\begin{array}{l}\text { Rua Lucena, 661, } \\
\text { Jd. Novo Portugal }\end{array}$ & $\begin{array}{c}\text { Ressarcimento de } \\
\text { danos causados pelo } \\
\text { SAAE }\end{array}$ & $\begin{array}{c}\text { Rachaduras devido a } \\
\text { infiltração de água } \\
\text { do SAAE. }\end{array}$ \\
\hline & 6553 & 2010 & $\begin{array}{l}\text { Rua Itapuí, 101, } \\
\text { Jd. Novo Portugal }\end{array}$ & $\begin{array}{c}\text { Ressarcimento de } \\
\text { danos causados pelo } \\
\text { SAAE }\end{array}$ & $\begin{array}{c}\text { Rachaduras devido a } \\
\text { infiltração de água } \\
\text { do SAAE }\end{array}$ \\
\hline & 8490 & 2010 & $\begin{array}{l}\text { Rua Lucena, Jd. } \\
\text { Novo Portugal }\end{array}$ & $\begin{array}{l}\text { Contratação de } \\
\text { empresa para serviços } \\
\text { especializados }\end{array}$ & $\begin{array}{c}\text { solapamento em } 3 \\
\text { imóveis devido a } \\
\text { vazamento. }\end{array}$ \\
\hline 2 & 5462 & 2012 & $\begin{array}{c}\text { Rua Maria da } \\
\text { Conceição, Ponte } \\
\text { Grande }\end{array}$ & $\begin{array}{c}\text { Ressarcimento de } \\
\text { danos causados pelo } \\
\text { SAAE }\end{array}$ & \\
\hline 3 & 5296 & 2003 & $\begin{array}{c}\text { Rua Lázaro de } \\
\text { Almeida } \\
\text { Campos, } 150 \mathrm{Pq} . \\
\text { Mikail }\end{array}$ & $\begin{array}{l}\text { CONTRATAÇÃO } \\
\text { EMPRESA } \\
\text { ESPECIALIZADA }\end{array}$ & $\begin{array}{c}\text { Contratação de } \\
\text { empresa para } \\
\text { execução de muro } \\
\text { de arrimo, danos } \\
\text { devido a } \\
\text { vazamentos. } \\
\end{array}$ \\
\hline 4 & 378 & 2012 & $\begin{array}{l}\text { Rua Estrela do } \\
\text { Oeste, 124, ant. } \\
701 \text { Jd. São } \\
\text { Geraldo }\end{array}$ & Ressarcimento & $\begin{array}{c}\text { Desmoronamento de } \\
\text { talude em função de } \\
\text { vazamento. }\end{array}$ \\
\hline
\end{tabular}




\begin{tabular}{|c|c|c|c|c|c|}
\hline & $\mathbf{N}^{\mathbf{o}}$ & Ano & Endereço & Assunto & $\begin{array}{c}\text { Observações } \\
\text { (contidas nos } \\
\text { processos) } \\
\end{array}$ \\
\hline 5 & 1760 & 2006 & $\begin{array}{l}\text { Rua Fluorita, } \mathrm{n}^{\circ} \\
\text { 14-B, Pq. } \\
\text { Primavera e Rua } \\
\text { Conceição do } \\
\text { Bananal, n' } 15-\mathrm{F}, \\
\text { Vila União }\end{array}$ & $\begin{array}{c}\text { Contratação de } \\
\text { empresa para serviços } \\
\text { especializados }\end{array}$ & $\begin{array}{l}\text { recalque devido a } \\
\text { vazamentos }\end{array}$ \\
\hline 6 & 7551 & 2008 & $\begin{array}{c}\text { Rua Jeronimo } \\
\text { Monteiro, } \mathrm{n}^{\circ} 7 \mathrm{~A}, \\
\text { Jardim Paraíso }\end{array}$ & $\begin{array}{c}\text { Contratação de } \\
\text { empresa para serviços } \\
\text { especializados }\end{array}$ & \\
\hline 7 & 866 & 2009 & $\begin{array}{c}\text { Rua Justiniano } \\
\text { Salvador dos } \\
\text { Santos, Pq. Mikail }\end{array}$ & $\begin{array}{c}\text { Contratação de } \\
\text { empresa para serviços } \\
\text { especializados }\end{array}$ & $\begin{array}{l}\text { danos a } 5 \text { imóveis } \\
\text { devido a vazamento }\end{array}$ \\
\hline 8 & 6076 & 2011 & $\begin{array}{c}\text { Rua Mariópolis, } \\
\text { Recreio de São } \\
\text { Jorge }\end{array}$ & $\begin{array}{c}\text { CONSTAÇÃO DE } \\
\text { DANOS CAUSADOS } \\
\text { P/VAZAMENTO } \\
\end{array}$ & $\begin{array}{l}\text { Recalque devido a } \\
\text { vazamentos, utilizar }\end{array}$ \\
\hline 9 & 5495 & 2009 & $\begin{array}{l}\text { Ruas Porto Seguro } \\
\text { e Itacarambi, Vila } \\
\text { Dinamarca }\end{array}$ & $\begin{array}{c}\text { Contratação de } \\
\text { empresa de engenharia }\end{array}$ & $\begin{array}{l}\text { Problemas em } 5 \\
\text { imóveis devido } \\
\text { rompimento de rede } \\
\text { de } 75 \mathrm{~mm} \text { - utilizar }\end{array}$ \\
\hline 10 & 5683 & 2008 & $\begin{array}{l}\text { Rua Renato Russo, } \\
\text { Jd. São Domingos }\end{array}$ & $\begin{array}{l}\text { Contratação de } \\
\text { empresa de engenharia }\end{array}$ & \\
\hline 11 & 4844 & 2004 & $\begin{array}{c}\text { Rua Salvador } \\
\text { Gorgone, Gopouva }\end{array}$ & $\begin{array}{l}\text { Contratação de } \\
\text { empresa de engenharia }\end{array}$ & $\begin{array}{c}\text { Contratação de } \\
\text { empresa para } \\
\text { execução de muro } \\
\text { de arrimo }\end{array}$ \\
\hline 12 & 3025 & 2013 & $\begin{array}{l}\text { Rua Leste A, 526, } \\
\text { Ponte Alta }\end{array}$ & $\begin{array}{c}\text { Comunicação de } \\
\text { ocorrência e } \\
\text { solicitação de serviços } \\
\text { - deslizamento }\end{array}$ & $\begin{array}{c}\mathrm{n}^{\mathbf{o}} \text { ocorrência na } \\
\text { Defesa Civil } 15.524, \\
\text { acidente ocorreu } \\
\text { devido descarga de } \\
\text { água. }\end{array}$ \\
\hline 13 & 4279 & 2012 & $\begin{array}{l}\text { Rua Olho d'Água } \\
\text { dos Borges }\end{array}$ & $\begin{array}{c}\text { Ressarcimento por } \\
\text { danos causados pelo } \\
\text { SAAE/ Ressarcimento } \\
\text { por danos causados } \\
\text { por obra do SAAE }\end{array}$ & \\
\hline 14 & & & $\begin{array}{c}\text { Rua } 110, \text { Pq. } \\
\text { Continental }\end{array}$ & & \\
\hline 15 & & & $\begin{array}{c}\text { Rua Clemente } \\
\text { Ferreira } \\
\end{array}$ & & \\
\hline 16 & & & $\begin{array}{c}\text { Rua Nelson Acto } \\
\text { de Jesus - Ponte } \\
\text { Alta } \\
\end{array}$ & & \\
\hline 17 & & & $\begin{array}{l}\text { Rua Margarida - } \\
\text { Recreio São Jorge }\end{array}$ & & \\
\hline 18 & & & $\begin{array}{c}\text { Rua Itororó - } \\
\text { Recreio São Jorge }\end{array}$ & $\begin{array}{l}\text { Ruptura da rede de } \\
\text { PVC com } \emptyset 50 \mathrm{~mm}\end{array}$ & \\
\hline 19 & & & $\begin{array}{c}\text { Rua João Roberto } \\
\text { de Miranda - Pq. } \\
\text { Continental } \\
\end{array}$ & $\begin{array}{l}\text { Ruptura da rede de } \\
\text { PEAD com } \varnothing 200 \text { mm }\end{array}$ & $\begin{array}{l}\text { Não houve danos } \\
\text { estruturais }\end{array}$ \\
\hline
\end{tabular}




\subsection{Metodologia}

A álgebra de mapas consiste no cruzamento de dois ou mais mapas para se chegar a um novo mapa, com novas informações (PARANHOS FILHO, 2008). Nesta etapa, com os valores estabelecidos para cada classe dos mapas de geologia, pedologia e declividade, procedeu-se o cruzamento entre eles, trazendo como resultado a carta de vulnerabilidade natural, que nada mais é que a média aritmética dos valores de vulnerabilidade de cada classe.

Esse resultado foi posteriormente distribuído em 5 classes, baseando-se em Grigio (2003):

- Muito baixa (de 1,0 a 1,3 de vulnerabilidade).

- Baixa (de 1,4 a 1,7 de vulnerabilidade).

- Média (de 1,8 a 2,2 de vulnerabilidade).

- Alta (de 2,3 a 2,5 de vulnerabilidade).

- Muito alta (maior ou igual a 2,6 de vulnerabilidade).

Já para a obtenção da carta de vulnerabilidade ambiental, procedeu-se o cruzamento entre a carta de vulnerabilidade natural com o mapa de uso e ocupação do solo, ponderandose os fatores, possibilitando-se assim a compensação entre os fatores através de um conjunto de pesos que indicam a importância de qualquer fator em relação aos demais (Grigio, 2003).

A Tabela 7 expressa a ponderação dos pesos. Os resultados obtidos também foram distribuídos em 5 classes de vulnerabilidade ambiental, semelhante às classes utilizadas na carta de vulnerabilidade natural.

Tabela 7. Ponderação dos fatores para análise das vulnerabilidades.

\begin{tabular}{cc}
\hline \multicolumn{2}{c}{ Fatores } \\
\hline Vulnerabilidade Natural & Uso do Solo \\
\hline 0,4 & 0,6 \\
\hline
\end{tabular}

Os pesos foram ponderados de forma que no mapa de vulnerabilidade ambiental o uso do solo tivesse um peso maior (no caso 60\%), enquanto que os fatores utilizados para determinação da vulnerabilidade natural tivessem pesos equivalentes entre eles.

\subsection{Resultados e Discussão}

\subsubsection{Vulnerabilidade Natural}


Como resultado do cruzamento dos dados de geologia, declividade e solos obteve-se o mapa de vulnerabilidade natural, visualizado na Figura 14. Observando-o, tem-se que a maior parte do Município de Guarulhos apresenta vulnerabilidade natural alta, no compartimento norte em razão principalmente do fator declividade e ao sul as maiores vulnerabilidades ocorrem em função da pedologia. A área urbanizada se concentra na planície aluvionar do Rio Tietê onde o material do substrato é inconsolidado e de fácil desagregação, o que facilita a incidência de processos erosivos.

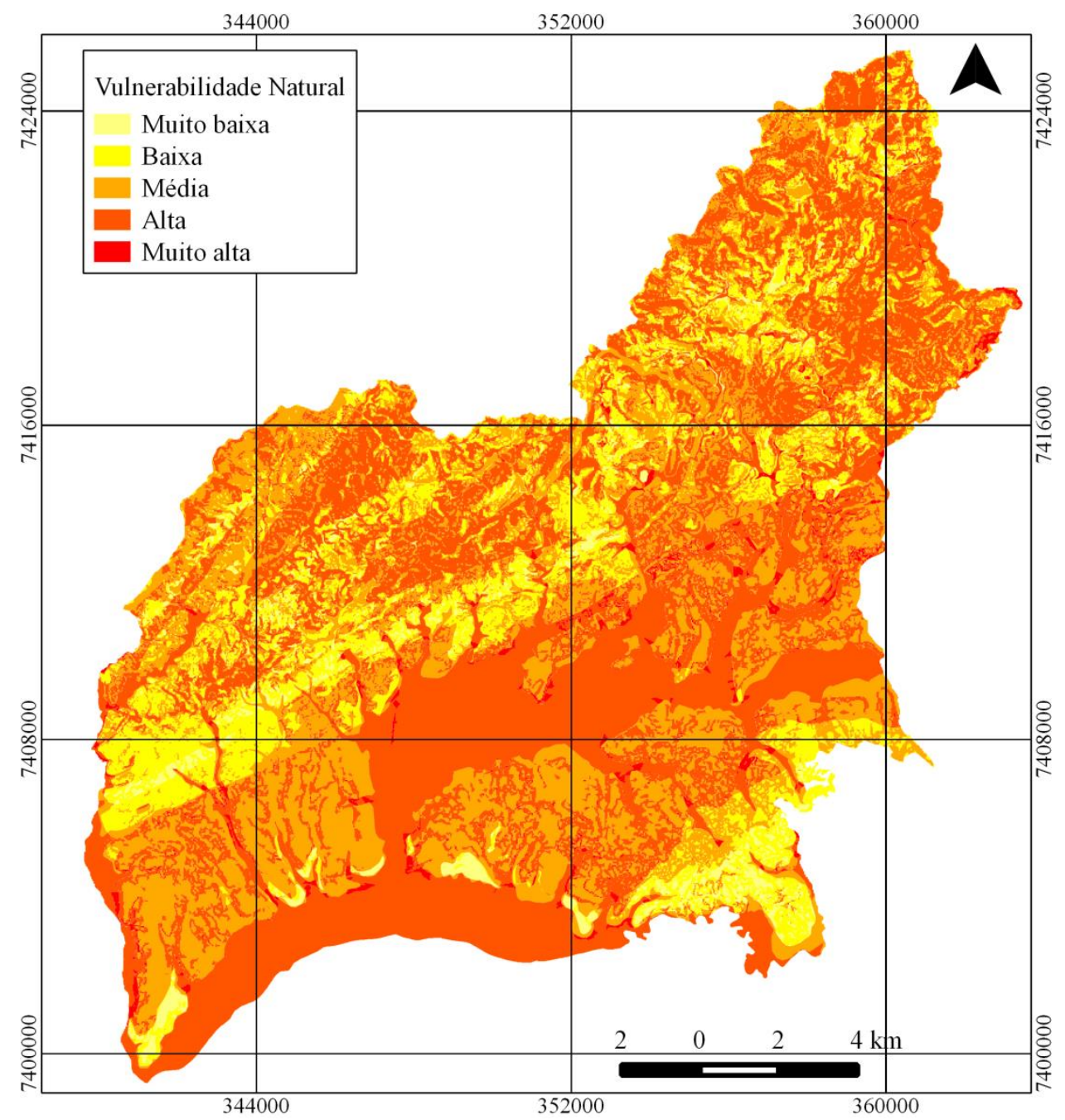

Figura 14. Mapa de vulnerabilidade natural do Município de Guarulhos, SP.

Na região de serra, onde as rochas são mais antigas, o substrato tem elevado grau de resistência à desagregação. Nesse ambiente os processos erosivos têm menor influência, sendo os processos de movimento de massas mais atuantes, em conjunto com as altas declividades. Nesta área a urbanização é recente, porém trata-se da região onde a mancha urbana tende a se expandir. 
Na Tabela 8 é possível visualizar os valores em área e em porcentagem relativos às vulnerabilidades natural e ambiental.

Tabela 8.Valores de vulnerabilidade natural do Município de Guarulhos.

\begin{tabular}{|c|c|c|}
\hline Vulnerabilidade Natural & Área $\left(\mathbf{k m}^{2}\right)$ & Porcentagem (\%) \\
\hline Muito baixa & 9 & 3 \\
\hline Baixa & 48 & 15 \\
\hline Média & 105 & 33 \\
\hline Alta & 150 & 47 \\
\hline Muito alta & 6 & 2 \\
\hline Total & 318 & 100 \\
\hline
\end{tabular}

Ao se relacionar o mapa de vulnerabilidade natural produzido neste trabalho com os eventos levantados de acidentes geológicos (Figura 15) tem-se que a maioria dos casos aconteceu em locais de VN alta ( 7 casos) e média e baixa (5 casos cada). Nota-se, portanto que a maioria dos casos ocorreu em consequência principalmente das altas declividades encontradas na região norte do município.

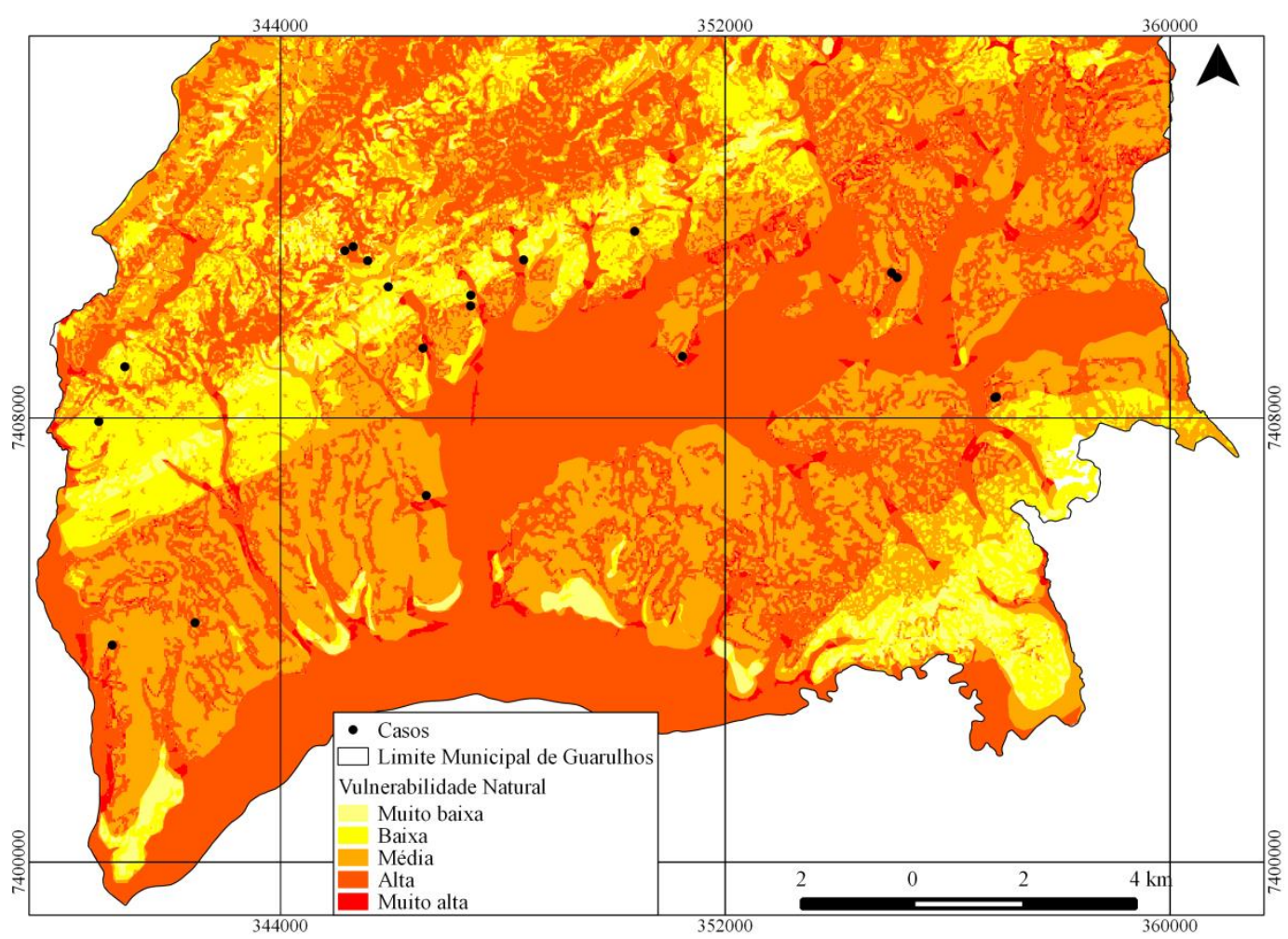

Figura 155. Casos de acidentes registrados lançados sobre o mapa de vulnerabilidade natural, coincidindo com áreas de média e alta vulnerabilidades.

\subsubsection{Vulnerabilidade Ambiental}


O mapa de vulnerabilidade ambiental, obtido através do cruzamento do mapa de vulnerabilidade natural com o uso e ocupação do solo é visualizado na Figura 16. Na Tabela 9 são apresentadas as porcentagens de cada classe de vulnerabilidade ambiental encontradas.

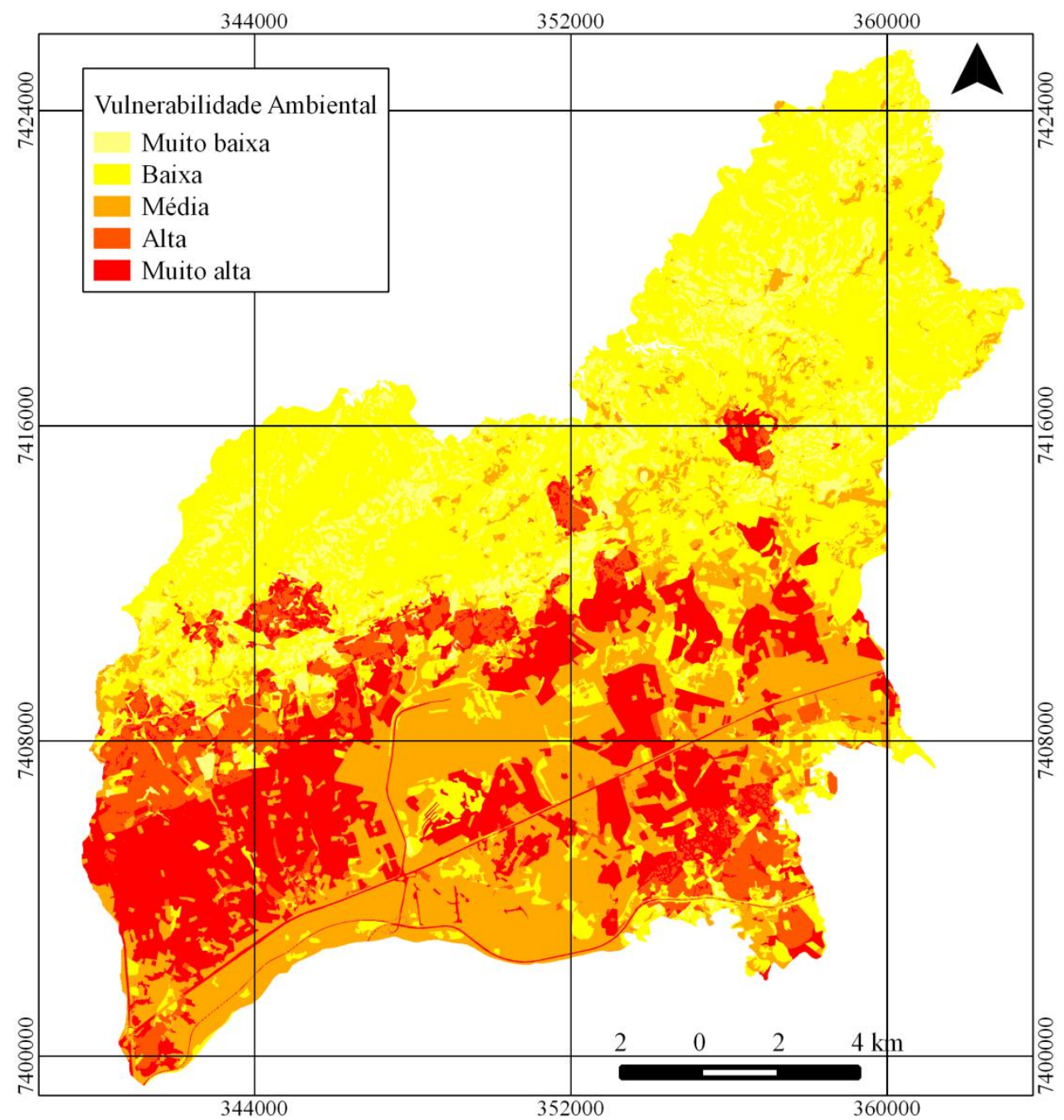

Figura 166. Mapa de vulnerabilidade ambiental do Município de Guarulhos, SP.

Tabela 9. Valores de vulnerabilidade ambiental do Município de Guarulhos.

\begin{tabular}{|c|c|c|}
\hline Vulnerabilidade Ambiental & Área $\left(\mathrm{km}^{2}\right)$ & Porcentagem (\%) \\
\hline Muito baixa & 25 & 8 \\
\hline Baixa & 133 & 42 \\
\hline Média & 76 & 24 \\
\hline Alta & 21 & 7 \\
\hline Muito alta & 61 & 19 \\
\hline Total & 317 & 100 \\
\hline
\end{tabular}

Observando-se os valores encontrados, tem-se que a maior parte do município apresenta vulnerabilidade baixa, em função da grande área preservada ao norte do Município. 
Entretanto, nas regiões mais densamente urbanizadas, os dados de vulnerabilidade passam a ser de médio a muito vulnerável, áreas de urbanização mais antiga e mais consolidada.

As altas vulnerabilidades estão associadas aos terrenos Cenozóicos e regiões com alta declividade, tornando-se áreas propicias à ocorrência de processos erosivos e movimentos de massa, respectivamente. Ao se relacionar o mapa de vulnerabilidade ambiental produzido neste trabalho com os sinistros levantados (Figura 17) tem-se que a maioria dos casos aconteceu em locais de VA média a muito alta. Este fato deve-se em função dos casos terem sido registrados em áreas urbanizadas e assim continham pesos altos em função desse fator.

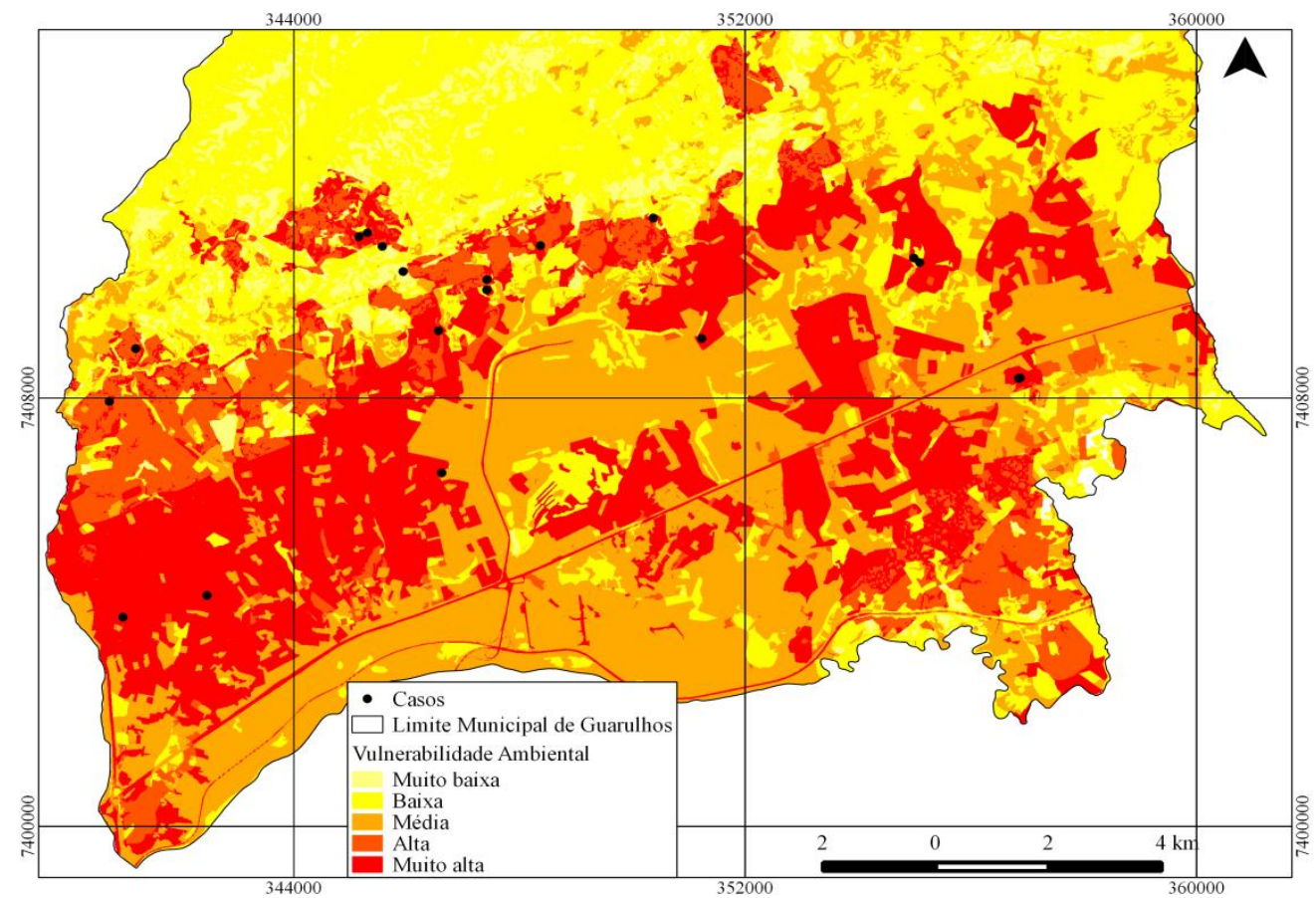

Figura 17. Casos de acidentes sobre o mapa de vulnerabilidade ambiental.

No Quadro 1 apresenta-se o número de casos relacionados às cartas de vulnerabilidade natural e ambiental.

Quadro 1. Número de acidentes geológicos em áreas vulneráveis.

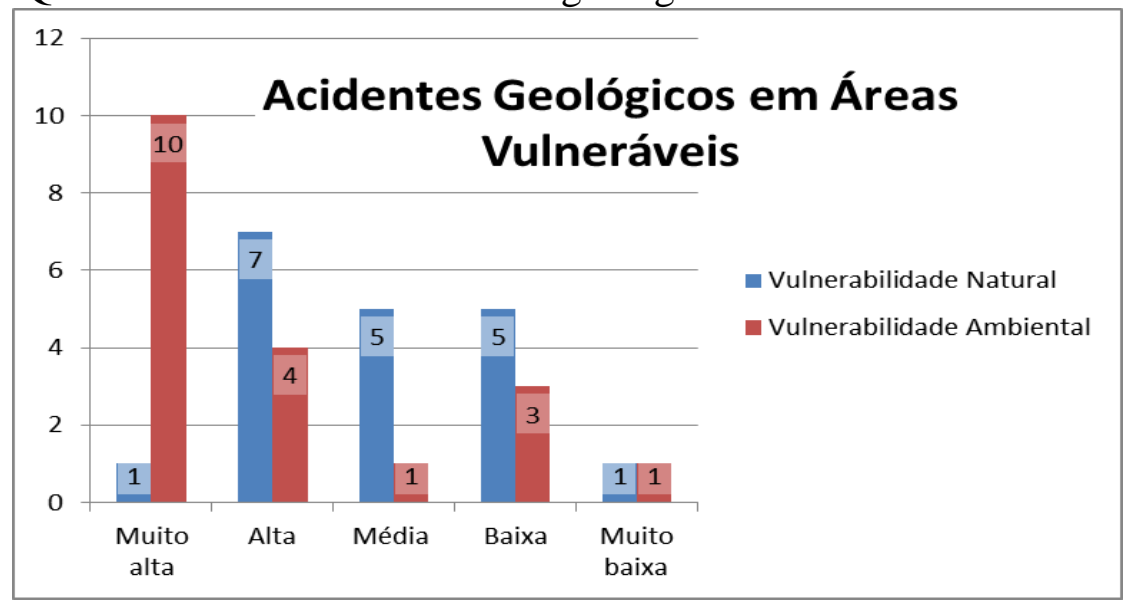




\subsection{Conclusões}

A metodologia de álgebra de mapas utilizada neste trabalho mostrou-se eficiente na elaboração das cartas de vulnerabilidade natural e ambiental para o Município de Guarulhos, podendo assim ser utilizadas como ferramentas de gestão e apoio à tomada de decisão, auxiliando, principalmente, no planejamento urbano.

Analisando-se a vulnerabilidade natural, tem-se que o Município de Guarulhos apresenta, em sua maior parte, vulnerabilidade natural alta.

Em relação à vulnerabilidade ambiental, tem-se que a maior parte do município encontra-se em situação de baixa a média vulnerabilidade ambiental. Entretanto, as grandes aglomerações urbanas encontram-se em região de vulnerabilidade alta, representados pelos altos pesos atribuídos às áreas de urbanização consolidada. 


\section{GEOTECNOLOGIAS PARA DETERMINAÇÃO DE VULNERABILIDADE À OCORRÊNCIA DE VAZAMENTOS NA REDE DE ABASTECIMENTO DE ÁGUA}

\subsection{Introdução}

O Brasil possui um índice de atendimento de água superior a $80 \%$, porém uma grande parcela da água que é tratada não chega às torneiras em função de perdas ao longo do sistema de distribuição. Estima-se que em média $40 \%$ do total de água tratada no Brasil é desperdiçada principalmente através de vazamentos (SNIS, 2009).

Segundo a International Water Association, IWA (2002), as perdas em sistemas de abastecimento de água tornaram-se, neste século, a principal preocupação das companhias de saneamento, não só do Brasil, mas no mundo todo.

Através do estudo para redução das perdas físicas é possível minimizar os impactos causados pelos vazamentos e rompimentos de tubulações, diminuindo os custos de produção da água tratada - mediante redução do consumo de energia, de produtos químicos e outros mitigando as consequências dessas perdas sobre o meio físico (SILVA, 1998).

Desta maneira, tendo como realidade global o cenário de escassez hídrica, torna-se mais do que necessário o desenvolvimento de metodologias que visem uma gestão eficiente dos recursos hídricos pelas companhias de saneamento.

Assim, a adoção de técnicas computacionais auxilia na tomada de decisões, por meio de um melhor planejamento de ações, gerenciamento e operacionalização dos sistemas de abastecimento de água, pelo fato de antecipar (através das simulações) o comportamento do sistema, cooperando para diminuir o impacto causado pelas perdas de água.

Em Guarulhos, em função do grande número de manutenção de vazamentos, algumas vezes não é possível evitar ocorrências em imóveis, processos erosivos e danos estruturais (SAVINO e FRANCISCO, 2005), como os identificados através da pesquisa de sinistros. Desta forma, foi identificado que os rompimentos de tubulações no SAAE (Serviço Autônomo de Água e Esgoto) de Guarulhos acontecem principalmente devido:

- A existência de áreas com pressões elevadas acima da capacidade de resistência das tubulações;

- Aos acidentes ocasionados por escavações ou por cargas excessivas que solicitam o pavimento em determinado trecho de rede; 
- A execução de curvas e conexões sem ancoragem apropriada.

- Ao assentamento inadequado de tubulações;

- A demora na manobra de registros, causada pela deficiência ou inacessibilidade aos mesmos, ou por atraso no atendimento;

- Às falhas inerentes aos materiais das tubulações;

- A ausência, limitação ou falha no sistema de monitoramento de pressões/vazões e outros parâmetros hidráulicos, tais como nível em reservatórios, em pontos estratégicos, para uma operação eficiente e segura da malha de adução e distribuição de água.

Desde 2005, o SAAE tem se mobilizado para diminuir as perdas de água no sistema, e conseguiu evoluir de aproximadamente 56\% para 37\% em 2012 (SNIS, 2014). As ações têm se concentrado principalmente em melhorar a qualidade das instalações, através de maior rigor no acompanhamento de obras e manutenções, controle do sistema de abastecimento através de telemetria, diminuição do tempo de manutenção de vazamentos e diminuição de pressões elevadas na rede.

\subsection{Materiais}

\subsubsection{Sistema de abastecimento de água de Guarulhos}

O abastecimento de água no Município é realizado pelo Serviço Autônomo de Água e Esgoto (SAAE), que foi criado em 30 de junho de 1967 sob a forma de autarquia municipal, com personalidade jurídica de direito público.

O sistema de abastecimento de água de Guarulhos distribui uma vazão média de 4,165 m³/s, de acordo com os dados coletados em janeiro de 2012, referentes ao ano de 2011. O índice de atendimento é de cerca de 98\%, abastecendo em torno de 345 mil ligações (SAAE, 2014). As tubulações do sistema são predominantemente de ferro fundido e PVC, havendo também uma pequena quantidade de outros materiais, como o polietileno de alta densidade (PEAD).

Do total da vazão distribuída, 3,636 m³/s (87\%) são importados da Sabesp e $0,529 \mathrm{~m} 3 / \mathrm{s}(13 \%)$ produzidos com recursos hídricos provenientes de fontes próprias do SAAE. Entretanto, o Município sofre ainda com a insuficiência de recursos hídricos, agravada pelo alto índice de perdas de água no sistema (PMG, 2011). Assim sendo, o município recorre ao sistema de rodízio de água (interrupções programadas no fornecimento) para atender toda a 
população, o que provoca intermitência na rede e, por conseguinte, agrava o problema de vazamentos, devido a grande variação de pressão na rede, que aumenta os esforços na parede da tubulação.

De modo geral, o sistema possui cerca de $2.200 \mathrm{~km}$ de redes, 23 centros de reservação e mais de 50 unidades de bombeamento (estações elevatórias e boosters).

Em 2003, o Plano Municipal de Água e Esgoto elencou as principais metas a serem cumpridas pelo Município em horizontes de curto, médio e longo prazo:

- Aumentar a produção própria em 500 1/s no curto prazo (até 2015);

- Aumentar para $100 \%$ a cobertura do abastecimento de água no curto prazo;

- Reduzir o índice de perdas global para 35\% no curto prazo (2010/2019) e para $25 \%$ no médio prazo (2020/2029), mantendo-se esse valor até o final de plano (2030/2039).

Desde então, a autarquia vem se esforçando para cumprir essas metas, impulsionadas, em 2014, pela crise de abastecimento de água, que tem afetado diretamente o município.

\subsubsection{Dados vetoriais}

Neste trabalho, para a identificação de áreas suscetíveis a vazamentos, foram utilizados dados de pressão máxima na rede, idade de instalação das tubulações e recorrência de manutenções. Estes dados foram apontados por técnicos da autarquia como sendo algumas das principais causas de rompimentos de tubulações no município e pela disponibilidade de dados, foram escolhidos para análise.

\section{- Pressão na rede}

Andreou, Marks e Clark (1987, apud Sarzedas, 2009) consideraram que o estresse imposto na parede da tubulação devido à alta pressão contribui para a ocorrência de uma quebra se a parede já está erodida devido à corrosão e apontaram o efeito significativo da pressão nas tubulações com múltiplas quebras.

A pressão também se constitui importante para a análise de vazamentos, pois indica o valor de vazão do vazamento. Assim, quanto maior o valor da pressão, maior será a vazão de água perdida através do vazamento. Desta forma, é importante salientar que a pressão de serviço está intimamente relacionada aos vazamentos nas redes de distribuição de água. Quando essa pressão é elevada, são gerados dois problemas, o primeiro se refere à frequência 
de rompimento das tubulações, o segundo é em relação ao aumento das vazões dos vazamentos, originando grandes perdas físicas no sistema (TARDELLI FILHO, 2006).

Os dados para pressão na rede foram obtidos através de estudo desenvolvido para o SAAE de Guarulhos de modelagem hidráulica da rede: "Estudos e projetos de implantação das Zonas de Medição e Controle (ZMCs)”, (SAAE, 2008). Através desse estudo foram gerados diversos modelos que representam a rede de abastecimento de água de Guarulhos por meio de trechos (que representam as tubulações) ligados a nós e demais dispositivos da rede (reservatórios, bombas e válvulas).

Com esses modelos foram realizadas simulações através das quais é possível obter informações da carga hidráulica nos nós e vazões nos trechos ao longo do dia, que são alterados conforme a variação de consumo. Foram efetuadas simulações para todos os setores de abastecimento de água de Guarulhos no instante de menor consumo (ocorrendo geralmente durante a noite), onde se obtém as maiores pressões nas redes de distribuição devido à menor perda de carga nas mesmas.

Os modelos foram então simulados por meio do software WaterCAD V8i, (BENTLEY WaterCAD, 2010) e foram gerados valores de pressão para cada nó que foram exportados para o formato shapefile, a fim de serem utilizados na álgebra de mapas em SIG (sistema de informação geográfica).

A partir dos pontos gerados, criou-se um Diagrama de Voronoi no software Quantum GIS 2.0 (QGIS Development Team, 2013), para representar as áreas de influência de cada um dos pontos de pressão (Figura 18). Os polígonos Voronoi são gerados de forma automática e constituem uma técnica para definição de áreas de influência, de tal forma que as bordas de polígonos adjacentes encontram-se equidistantes de seus respectivos pontos geradores (no caso os nós do modelo hidráulico da rede) (Rezende; Almeida e Nobre, 2000).

Quanto à questão da influência da pressão na ocorrência de quebras é preciso salientar que com o passar dos anos a maioria dos setores de abastecimento tiveram várias mudanças nos seus limites. Portanto, a situação das pressões atuais em muitos casos é bem diferente das situações de 10, 20,30 anos atrás. O processo de instalação intensiva de válvulas redutoras de pressão é relativamente recente, ou seja, a grande parte das tubulações já estava operando há mais de 30 anos. Desta forma o modelo representa uma situação de pior caso quanto aos valores de pressão. 


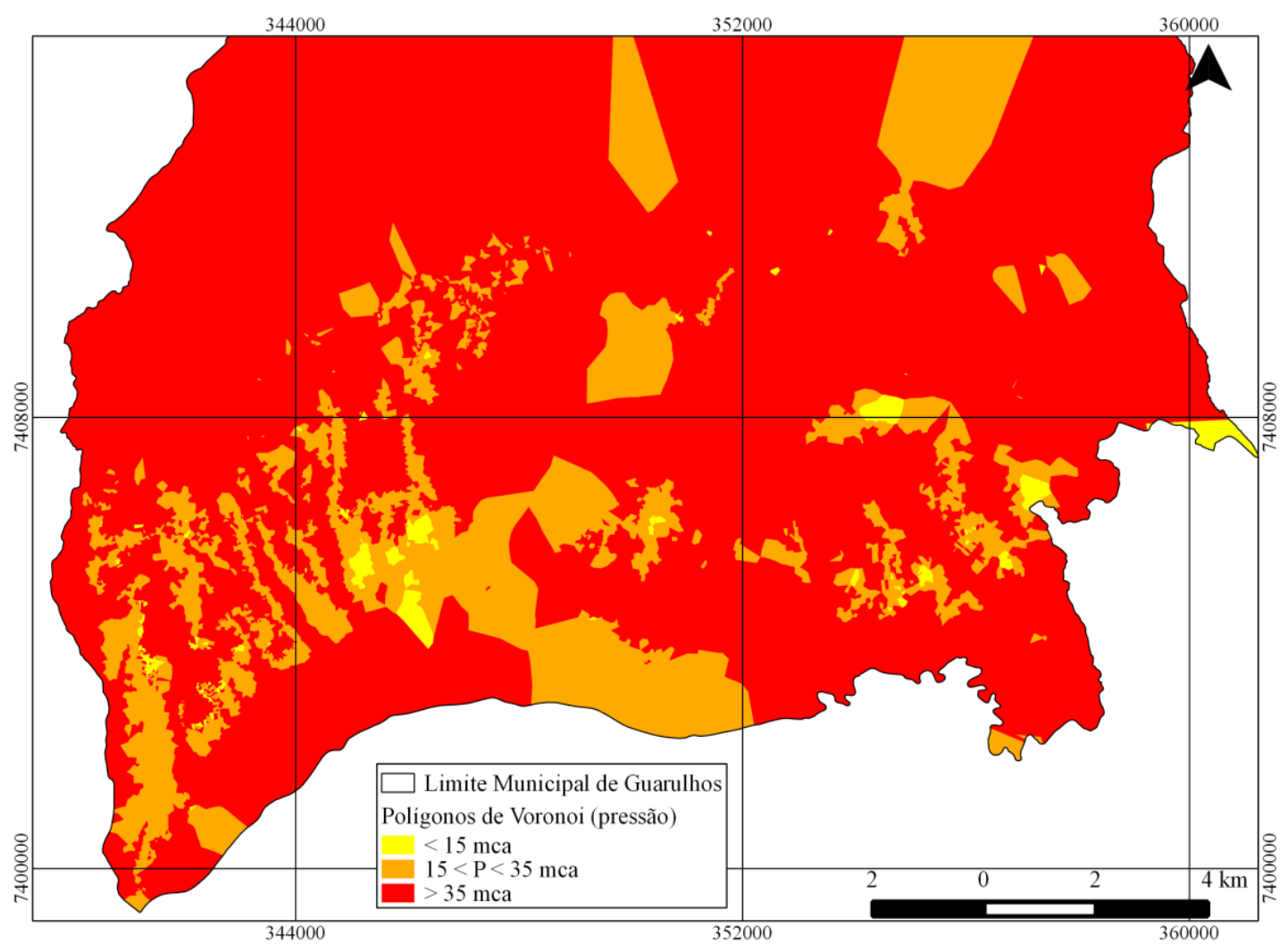

Figura 17. Diagramas de Voronoi dos valores de pressão para o Município de Guarulhos. Nota-se que na maior parte do município a pressão é maior que 35 mca.

Para a redução de vazamentos, o SAAE tem como objetivo a redução da pressão em até $35 \mathrm{mca}$ (equivalente à $350 \mathrm{KPa}$ ), desta forma foi admitido o peso máximo para valores acima desta meta (Tabela 10). A pressão mínima determinada por norma (NBR 12218/1994) é de $10 \mathrm{mca}(100 \mathrm{KPa})$ na entrada do hidrômetro, portanto definiu-se o menor peso para 15 mca $(150 \mathrm{KPa})$, valor satisfatório de pressão para atendimento dos usuários.

Tabela 10. Pesos estabelecidos para cada classe de pressão.

\begin{tabular}{cc}
\hline Classes & Pesos \\
\hline Abaixo de $15 \mathrm{mca}$ & 1,2 \\
De 15 a $35 \mathrm{mca}$ & 2,0 \\
Acima de $35 \mathrm{mca}$ & 3,0 \\
\hline
\end{tabular}

- Faixa etária da tubulação

Dentre os principais fatores que influenciam as perdas físicas nas redes de distribuição de água está a condição física da infraestrutura, que inclui o fator de idade da rede. 
Após a instalação da tubulação, com o decorrer dos anos esses tubos são atacados por fenômenos de natureza química relativa aos minerais presentes na água ou presentes no solo. Assim, Azevedo Neto et al (1998) evidencia que, em uma tubulação de ferro fundido, por exemplo, podem surgir reentrâncias (devido à corrosão) ou protuberâncias, conhecidas como “tubérculos”. Outra situação comumente encontrada é a deposição progressiva de substâncias contidas nas águas e formação de camadas aderentes, incrustrações, que ocorrem em casos de águas muito duras, com teores elevados de certas impurezas, sendo o mais comum a deposição progressiva de cálcio em águas calcáreas. Essas condições agravam-se com o tempo.

Para este trabalho, os dados de idade da rede foram retirados do estudo de "Serviços Técnicos de Engenharia para Atuar no Controle e Redução de Perdas do Sistema de Abastecimento de Água de Guarulhos" (SAAE, 2012), (Tabela 11). O levantamento dos dados de idade da rede foi realizado a partir dos dados contidos no Sistema de Informação Geográfica (SIG) do SAAE.

Tabela 11. Faixa etária das redes x extensão - Município de Guarulhos. Fonte: SAAE (2012)

\begin{tabular}{ccc}
\hline Faixa etária das redes & Extensão $(\mathbf{k m})$ & \% \\
\hline Até 05 anos & 88,80 & 3,94 \\
06 a 10 anos & 218,57 & 9,69 \\
11 a 15 anos & 194,27 & 8,61 \\
16 a 20 anos & 292,57 & 12,97 \\
21 a 25 anos & 225,23 & 9,99 \\
26 a 30 anos & 229,33 & 10,17 \\
31 a 35 anos & 144,97 & 6,43 \\
36 a 40 anos & 60,25 & 2,67 \\
Acima de 40 anos & 14,22 & 0,63 \\
Idade não informada & 788,95 & 34,90 \\
\hline Total & $2.255,16$ & 100 \\
\hline
\end{tabular}

Em Guarulhos, as redes mais antigas encontram-se na região central do Município, pelo fato de ser a primeira área a ser urbanizada, sendo a região a concentrar também a maioria das redes sem informação de idade (Figura 19). Esse fato ocorre em função dessas redes antigas não terem sido cadastradas, e por isso não haver informação disponível no Sistema de Informação Geográfica do SAAE. 


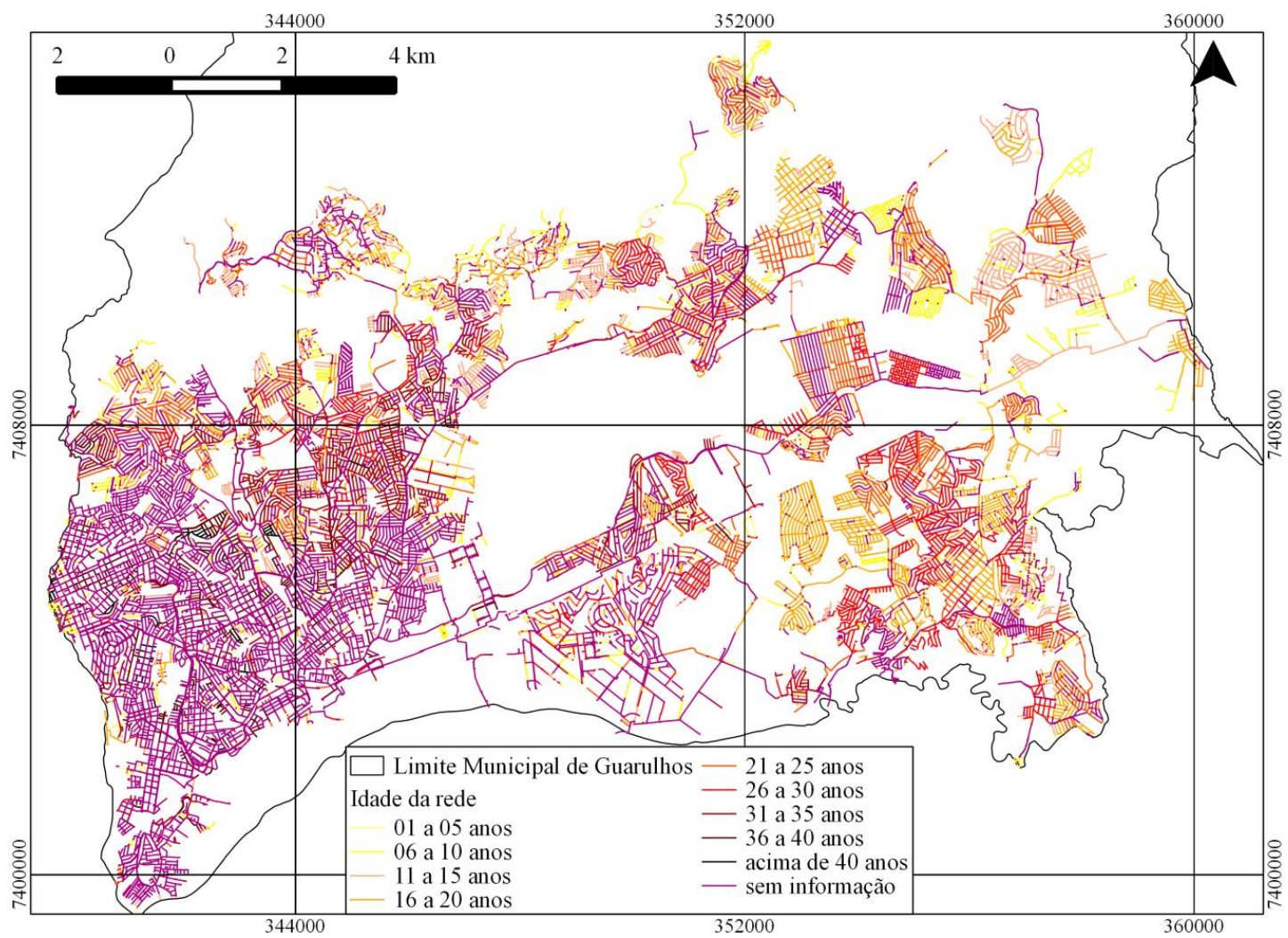

Figura 18 Distribuição das faixas etárias da rede de água de Gualhos. Percebe-se que grande parte da tubulação não possui informações quanto à idade.

Para o estabelecimento dos pesos (Tabela 12), foi considerado o peso máximo para as redes com idade acima de 20 anos. Para as redes sem informação foi considerado o peso máximo também, pelo fato de serem consideradas as redes mais antigas e sem cadastro (fato mencionado anteriormente).

Tabela 12. Valores estabelecidos para as faixas etárias da rede de água.

\begin{tabular}{cc}
\hline Classes & Pesos \\
\hline 01 a 05 anos & 1,2 \\
06 a 10 anos & 2 \\
11 a 15 anos & 2,5 \\
16 a 20 anos & 2,8 \\
21 a 25 anos & 3 \\
26 a 30 anos & 3 \\
31 a 35 anos & 3 \\
36 a 40 anos & 3 \\
Acima de 40 anos & 3 \\
Sem informação & 3 \\
\hline
\end{tabular}

- Manutenções recorrentes 
Levando-se em conta que as perdas reais nos sistema de distribuição de água são constituídas, basicamente, por vazamentos nas paredes de tubulações, conexões e seus acessórios, a análise de manutenções recorrentes torna-se importante para estabelecer áreas vulneráveis à ocorrência de vazamentos.

O número de falhas anteriores ou o histórico de falhas de uma tubulação é um fator significativo para a predição de futuras falhas (WALSKI e PELLICCIA, 1982 apud Sarzedas, 2009). Andreou, Marks e Clark (1987 apud Sarzedas,2009) também analisaram vazamentos nas redes de água e concluíram que a taxa de quebra aumentou a partir de cada evento, até a terceira quebra depois da qual a taxa de rompimentos ficou constante, mas elevada. Nesse ponto as tubulações foram definidas como "estado de quebra rápida". Desta forma, Sarzedas (2009) conclui que o número de quebras anteriores foi reconhecido por afetar significativamente a função de risco das tubulações.

A avaliação dos eventos de manutenção em redes do SAAE foi elaborada a partir do relatório fornecido pela companhia (SAAE, 2012): "Serviços Técnicos de Engenharia para Atuar no Controle e Redução de Perdas do Sistema de Abastecimento de Água de Guarulhos".

O levantamento destes eventos foi realizado a partir do banco de dados da autarquia, utilizado na gestão dos serviços de manutenção. Para isto foram espacializados por meio dos eixos de logradouros os eventos de manutenção recorrentes de redes, conforme Figura 20.

A Tabela 13 ilustra os valores estabelecidos para a vulnerabilidade das faixas de manutenção. O peso máximo foi atribuído para as redes que possuíam acima de quatro eventos de manutenção. 


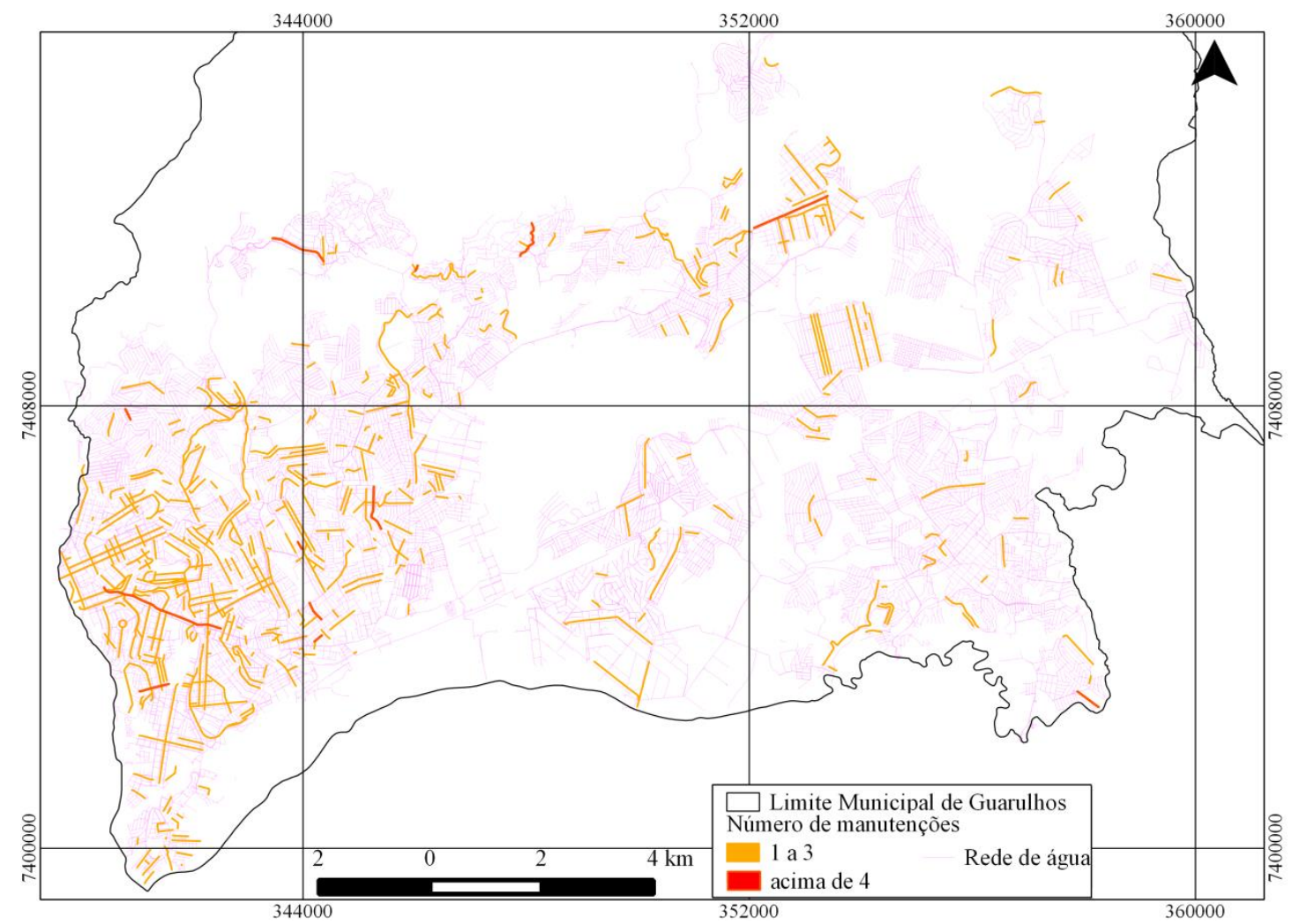

Figura 19. Distribuição do número de manutenções na rede de distribuição de água em Guarulhos.

Tabela 13. Pesos estabelecidos para as faixas de manutenção na rede.

\begin{tabular}{cc}
\hline Classes & Pesos \\
\hline 01 a 03 manutenções & 2 \\
Acima de 04 manutenções & 3 \\
\hline
\end{tabular}

\subsection{Metodologia}

A álgebra de mapas, já definida no capítulo anterior, foi aplicada novamente, nesta etapa utilizando-se os fatores condicionantes dos vazamentos e seus pesos definidos. Desta forma, os mapas foram cruzados a fim de se chegar a um mapa final com as classes de vulnerabilidade ranqueadas de muito baixa a muito alta.

Para a identificação da vulnerabilidade à ocorrência de vazamentos foi realizado o somatório dos pesos de idade e manutenção da rede, com intuito de atribuir maior valor de vulnerabilidade às redes que já haviam sofrido manutenções. Este somatório foi realizado através da ferramenta Union do ArcGIS 9.3 (ESRI, 2006).

Após a elaboração deste mapa prévio com os valores de idade e manutenção, foi acrescentado à álgebra de mapas a informações de pressão simulada do Município através da 
malha de polígonos Voronoi, e assim foi realizada a média aritmética para identificação das classes de vulnerabilidade.

Em seguida, o valor resultante dos pesos foi distribuído em 5 classes de vulnerabilidade:

- Muito baixa (de 1,2 a 1,8 de vulnerabilidade).

- Baixa (de 1,8 a 2,4 de vulnerabilidade).

- Média (de 2,4 a 3,0 de vulnerabilidade).

- $\quad$ Alta (de 3,0 a 3,6 de vulnerabilidade).

- Muito alta (maior ou igual a 3,7 de vulnerabilidade).

Com estes valores foi elaborado o mapa de vulnerabilidade à ocorrência de vazamentos na rede de abastecimento de água do Município de Guarulhos.

\subsection{Resultados e Discussão}

A carta de vulnerabilidade à ocorrência de vazamentos é apresentada na Figura 21.

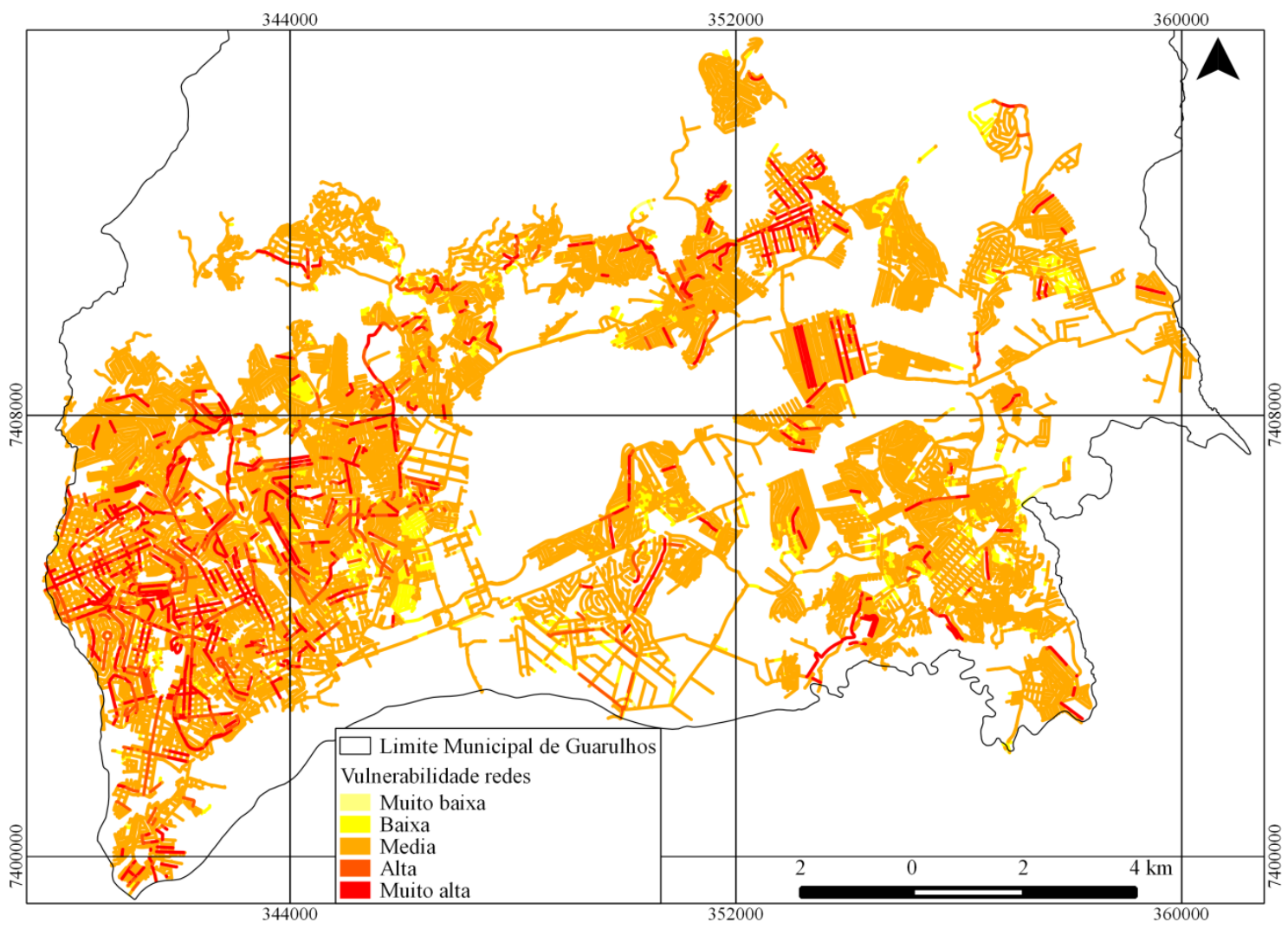

Figura 20. Carta de vulnerabilidade à ocorrência de vazamentos na tubulação de distribuição de água do Município de Guarulhos, SP. 
Através da análise do mapa gerado, identifica-se que a maior parte das redes com vulnerabilidade alta e muito alta encontra-se na região central, área onde se deu inicialmente a urbanização do município, ou seja, onde a infraestrutura começou a ser instalada e, portanto, onde a rede de abastecimento é mais antiga. $\mathrm{O}$ grande percentual de redes na classe de média suscetibilidade se deu pelo fato dessas redes ainda não terem sofrido manutenções recorrentes e possuírem pressões elevadas (Tabela 14).

Tabela 14. Valores encontrados para cada classe de vulnerabilidade à ocorrência de vazamentos.

\begin{tabular}{ccc}
\hline $\begin{array}{c}\text { Redes- Suscetibilidades a } \\
\text { Vazamentos }\end{array}$ & Área $\left(\mathbf{k m}^{2}\right)$ & Porcentagem $(\%)$ \\
\hline Muito baixa & 1 & 2 \\
Baixa & 10 & 10 \\
Média & 70 & 74 \\
Alta & 5 & 5 \\
Muito alta & 8 & 9 \\
Total & $\mathbf{9 3 . 9}$ & $\mathbf{1 0 0}$ \\
\hline
\end{tabular}

$\mathrm{Na}$ Figura 22 relacionam-se os eventos de acidentes geológicos previamente levantados juntamente com a carta de vulnerabilidade à ocorrência de vazamentos.

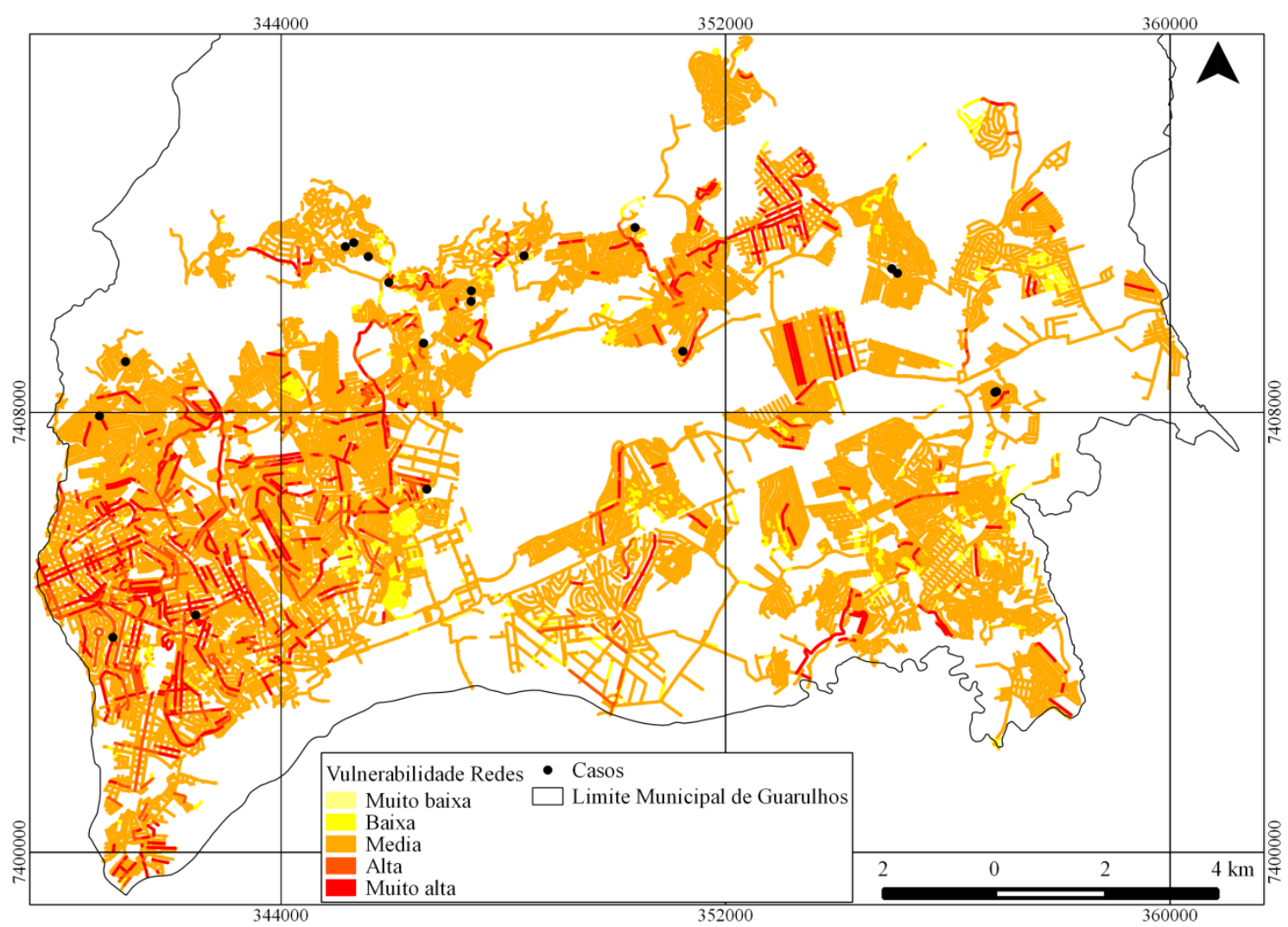

.Figura 21. Casos de acidentes geológicos sobre a carta de vulnerabilidade a vazamentos. 
Através da análise do mapa gerado, podemos notar que a maioria dos acidentes ocorreu em áreas de média vulnerabilidade, na área ao norte do Município, influenciados principalmente pelas altas pressões da rede geradas em função de ser uma área abastecida por meio de bombeamento, pelo fato de ser uma região com altas declividades (compartimento norte). Ao analisar-se os acidentes que ocorreram nesta área, nota-se que possuem a tipologia de movimentos de massa, ilustrados através das Figuras 6 e 7 de acidentes que ocorreram nestas áreas ao norte do Município (apresentadas no item 3.4 da Fundamentação Teórica).

\subsection{Conclusões}

A análise da carta de vulnerabilidade à ocorrência de vazamentos permite concluir que as redes com maior vulnerabilidade foram determinadas principalmente pelo fator de manutenções recorrentes. Desta forma, mostra-se importante o desenvolvimento de outra metodologia para utilização desse fator para majoração da vulnerabilidade.

A maioria dos casos de acidentes geológicos levantados encontra-se em redes com vulnerabilidade média, demonstrando que os demais fatores (idade e pressão) têm maior influência na deflagração desses eventos.

Para trabalhos futuros é sugerido que a análise estenda-se a outros fatores que propiciam o aparecimento de vazamentos, como por exemplo, tipo de material da rede, intermitência do sistema e influência do tráfego. 


\section{CONSIDERAÇÕES FINAIS}

O emprego das geotecnologias na realização de análises ambientais vem crescendo cada vez mais, principalmente por se mostrarem excelentes ferramentas no auxílio à tomada de decisão e por permitirem a utilização de dados de diversas fontes e formatos concomitantemente, mostrando-se assim uma ótima alternativa para a relação custo-benefício. Desse modo, a aplicação das geotecnologias pode atuar como suporte para a formação de medidas de intervenção, recuperação e prevenção de danos ambientais, propiciando melhores formas de explorar o ambiente em que se vive, de modo a diminuir os impactos causados e prevenir impactos futuros.

O primeiro capítulo permitiu identificar as áreas de vulnerabilidade natural e ambiental do Município de Guarulhos. Através do cruzamento dos dados de geologia, declividade e solos obteve-se a carta de vulnerabilidade natural, onde foi possível observar que a maior parte do município encontra-se em áreas de vulnerabilidade natural alta (47\%), a qual se concentra principalmente na região urbanizada. $\mathrm{O}$ cruzamento entre a carta de vulnerabilidade natural e os dados de uso e ocupação do solo resultou na carta de vulnerabilidade ambiental, a qual demonstrou que a maior parte de Guarulhos encontra-se em vulnerabilidade ambiental baixa (42\%), principalmente em função da grande área preservada a norte. Entretanto, nas regiões mais densamente urbanizadas, os dados de vulnerabilidade são de médio a muito vulnerável.

Em relação ao capítulo 2, tem-se que o cruzamento entre dados de pressão, manutenção e idade das redes identificou que a vulnerabilidade à ocorrência de vazamentos nas redes de distribuição de água do Município de Guarulhos é considerada em sua maior parte média (74\% de toda a área). Esse fato é influenciado principalmente pelo fator de manutenções recorrentes.

A maior parte do esforço empenhado na realização deste trabalho se deu em relação à correção dos dados utilizados como base, devido ao fato de que os mesmos apresentaram inconformidades quanto ao datum e projeção estabelecidos, assim como questões topológicas e ausência de metadados.

Salienta-se a importância da parceria estabelecida com a companhia de saneamento, pois a disponibilidade de dados foi essencial para o desenvolvimento da pesquisa.

A metodologia aplicada pode ser integralmente desenvolvida em programas livres de sistemas de informações geográficas, facilitando o acesso a órgãos públicos, solicitando apenas conhecimento dos profissionais que utilizarão esses programas. 


\section{REFERÊNCIAS BIBLIOGRÁFICAS}

ABC LOCAL. 7 News. Inspectors believe leak caused mysterious landslide. Disponível em: $<$ http://abclocal.go.com/kgo/story?section=news/local/north_bay\&id=9105336 Acesso em: Maio de 2013.

AGÊNCIA NACIONAL DE ÁGUAS e DEPARTAMENTO DE ÁGUAS E ENERGIA ELÉTRICA. Nota Conjunta ANA/DAEE, Fevereiro de 2014. Disponível em: < http://www2 .ana.gov.br/Paginas/servicos/outorgaefiscalizacao/GTAGCantareira.aspx >. Acesso em agosto de 2014.

ABNT. ASSOCIAÇÃO BRASILEIRA DE NORMAS TÉCNICAS. NBR - 12218: Projeto De Rede de Distribuição de Água Para Abastecimento Publico. Rio de Janeiro, 1994.

ANDRADE, M. R. M. Cartografia de Aptidão para Assentamento Urbano do Município de Guarulhos/SP. 1999. 154p. Dissertação de Mestrado em Geografia - Faculdade de Filosofia, Letras e Ciências Humanas, Universidade de São Paulo, São Paulo, 1999.

ANDREOU, S.; MARKS, D.H.; CLARK, R.M. (1987b). A new methodology for modeling break failure patterns in deteriorating water distribution systems: applications. Advances in Water Resources, v. 10, n. 1, p. 11-20, mar. 1987.

ARAÚJO, L. (2005) - "Controlo de Perdas na Gestão Sustentável dos Sistemas de Abastecimento de Água". Tese de Doutoramento. Instituto Superior Técnico, Universidade Técnica de Lisboa. 302 p.

AUGUSTO FILHO, O.; VIRGILI C. J. Estabilidade de Taludes. In: OLIVEIRA, A. M. S.; BRITO, S. N. A. Geologia de Engenharia - São Paulo: ABGE, 586 p., 1998.

AUGUSTO FILHO, O.A. (1992). Caracterização geológico-geotécnica voltada à estabilização de encostas: uma proposta metodológica. In: Conferencia Brasileira sobre Estabilidade de Encostas, 1, 1992, Rio de Janeiro. Anais. Rio de Janeiro. p. 721-733.

AZEVEDO NETTO, J. M., et al. - "Manual de Hidráulica", Ed. Edgard Blucher Ltda, 8 a Edição, São Paulo, 1998.

BENTLEY WATERCAD V8i. USERS MANUAL. Haestad Methods Inc. 2010.

BRASIL. Ministério do Meio Ambiente. Vulnerabilidade Ambiental: Desastres Naturais ou Fenômenos Induzidos? Brasília. 2007. 192 p.

CARRIJO, M. G. G. Vulnerabilidade ambiental: o caso do Parque Estadual das Nascentes do Rio Taquari. 2005. Dissertação (Mestrado em Saneamento Ambiental e Recursos Hídricos) - Programa de Pós-Graduação em Tecnologias Ambientais, Universidade Federal do Mato Grosso do Sul, Campo Grande, 2005.

CERRI, L. E. da S.; AMARAL, C. P. do. Riscos geológicos. In: OLIVEIRA, A. M. S.; BRITO, S. N. A. Geologia de Engenharia. São Paulo: Associação Brasileira de Geologia de Engenharia, 586p, 1998.

COUTINHO, J. M. V. (coord.). Carta geológica da Região Metropolitana da Grande São Paulo 1:100.000. São Paulo: EMPLASA - Secretaria dos Negócios Metropolitanos, 2 folhas (Guarulhos e Itaquaquecetuba). 1979. 
CREPANI, E. M. MEDEIROS, J. S. de. HERNANDEZ FILHO, P. FLORENZANO, T. G. DUARTE, V. BARBOSA, C. C. F. Sensoriamento remoto e geoprocessamento aplicados ao zoneamento ecológico econômico e ao ordenamento territorial. São José dos Campos - INPE, 2001 (INPE-8454-RPQ/72). 124 p.

DANTAS, A. S. L. Geologia da Faixa São Roque e intrusivas associadas na região entre São Paulo e Mairiporã, norte de São Paulo. 1990. Dissertação (Mestrado). São Paulo: Instituto de Geociências-USP. 1990.

ENVIRONMENTAL SYSTEMS RESEARCH INSTITUTE (ESRI). ArcGIS Professional GIS for the desktop, versão 9.3, 2006.

ESTADO DE SÃO PAULO ONLINE. Cratera na Oscar Freire foi provocada por vazamento de água. Disponível em: $<\mathrm{http} / / / w w w . e s t a d a o . c o m . b r / n o t i c i a s / c i d a d e s, c r a t e r a-n a-r u a-$ oscar-freire-foi-provocada- por-vazamento-de-agua,559160,0.htm> Acesso em: Maio de 2013.

FERNANDES, N.F.; AMARAL, C.P. Movimentos de massa, uma abordagem geológica-geomorfológica. In: GUERRA, A.J.T.; CUNHA, S.B. (Eds.). Geomorfologia e meio ambiente. Rio de Janeiro: Bertrand Brasil, Cap.3, p.123-194, 2003.

GOMES, G. L. C. C. 2008. Análise Geoambiental de áreas de risco a escorregamentos nos loteamentos do Recreio São Jorge e Novo Recreio, município de Guarulhos - SP. 2008. 97 p. Dissertação (Mestrado em Análise Geoambiental) - Centro de PósGraduação, Pesquisa e Extensão,Universidade Guarulhos, Guarulhos, 2008.

GOULTER, I. C., AND KAZEMI, A. Spatial and temporal groupings of water main pipe breakage in Winnipeg. Canadian J. Civil Engrg., 15(1), 91-97, 1998.

GRIGIO, A. M. Aplicação do sensoriamento remoto e sistemas de informação geográfica na determinação da vulnerabilidade natural e ambiental do município de Guaramé (RN): simulação de risco às atividades da indústria petrolífera. 2003. 230f. Dissertação (Mestrado em Geodinâmica) - Programa de Pós-Graduação em Geodinâmica e Geofísica, Universidade Federa do Rio Grande do Norte, Natal, 2003.

GUIDICINI, G. e NIEBLE, C. M. Estabilidade de taludes naturais e de escavação. Edgard Blücher, Ed. Da Universidade de São Paulo, São Paulo - SP, 170p. 1976.

INFANTI JUNIOR, N.; FORNASARI FILHO, N. Processos de Dinâmica Superficial. In: OLIVEIRA, A. M. S.; BRITO, S. N. A. Geologia de Engenharia. São Paulo: Associação Brasileira de Geologia de Engenharia, 586p, 1998.

INSTITUTO DE PESQUISAS TECNOLOÓGICAS. IPT. Investigação tecnológica de sinistros. 2013. Disponível em: http://www.ipt.br/solucoes/106investigacao_tecnologica_de_sinistros.htm.

INTERNATIONAL WATER ASSOCIATION. IWA. Water Management - Industry as a Partner for Sustainable Development. IWA, UNEP, United Kingdom, 60 p. 2002.

JULIANI, C. Geologia, petrogênese e aspectos metalogenéticos dos Grupos Serra do Itaberaba e São Roque na região das Serras do Itaberaba e da Pedra Grande, NE da cidade de São Paulo. 1993. 803p., 2v., 5 mapas. Tese (Doutorado). Instituto de Geociências-USP, São Paulo, 1993.

KLEINER, Y; RAJANI, B. Comprehensive review of estructural deterioration of water mains: statistical models. Urban Water, Canada, v. 3, n. 3, p.131-150, out. 2001. 
LANCASTER ONLINE. Massive sinkholes collapse Harrisburg roadway. Disponível em: $<$ http://lancasteronline.com/article/local/799707_Massive-sinkholes-collapseHarrisburg- roadway.html>. Acesso em: Maio de 2013

MINEROPAR - Serviço geológico do Paraná. Acidentes Geológicos Urbanos. Curitiba, 2010 ( $1^{\mathrm{a}}$ Edição), 78 p.

MORRIS, R.E. Principal causes and remedies for water main breaks. Journal of AWWA,USA, 1967.

NOGUEIRA JUNIOR, J.; MARQUES, A. S. Linhas de transmissão e dutovias. In: OLIVEIRA, A. M. S.; BRITO, S. N. A. Geologia de Engenharia - São Paulo: ABGE, 586 p., 1998.

OLIVEIRA, A.M.S.; ANDRADE, M. R. M.; QUEIROZ, W.; SATO, S. E. Análise Geoambiental aplicada a Microbacias Urbanas na região do Cabuçu, Guarulhos (SP). In: Congresso Brasileiro de Geologia de Engenharia, 11, Florianópolis/SC. Anais... em CD. São Paulo: ABGE. 2005a.

OLIVEIRA, A.M.S.; ANDRADE, M. R. M.; QUEIROZ, W.; SATO, S. E. Diagnóstico Ambiental para o Manejo Sustentável do Núcleo Cabuçu do Parque Estadual da Cantareira e Áreas Vizinhas do Município de Guarulhos. Guarulhos: Laboratório de Geoprocessamento. Universidade Guarulhos (Relatório Fapesp), 109 p., 2v., Mapas. 2005. b.

OLIVEIRA, A. M. S.; ANDRADE, M. R. M.; SATO, S. E.; QUEIROZ, W. Bases Geoambientais para um Sistema de Informações Ambientais do Município de Guarulhos. Guarulhos: Laboratório de Geoprocessamento da Universidade Guarulhos,2009. 178 p. 4v. Mapas (Relatório FAPESP - Processo 05/57965-1).

ONU - ORGANIZAÇÃO DAS NAÇÕES UNIDAS - 2004. Living with risk. A global review of disaster reduction initiatives. Inter-agency Secretariat International Strategy for Disaster Reduction (ISDR), Genebra - Suiça, www.unisdr.org. 398p. e anexos.

ORSINI, E. Q. Sistemas de abastecimento de água. Apostila da disciplina: PHD 412 Saneamento II. Escola Politécnica da Universidade de São Paulo. Departamento de Engenharia Hidráulica e Sanitária. São Paulo, SP, 1996.

PARANHOS FILHO, A. C.; LASTORIA, G.; TORRES, T. G. Sensoriamento Remoto Ambiental Aplicado: Introdução as Geotecnologias. Campo Grande: Editora da UFMS. 198 p. 2008.

PREFEITURA MUNICIPAL DE GUARULHOS - PMG. PEMAS. Plano Estratégico Municipal para Assentamentos Subnormais. Secretaria de Habitação da Prefeitura Municipal de Guarulhos. 2004.

PREFEITURA MUNICIPAL DE GUARULHOS - PMG. Plano Diretor de Drenagem Diretrizes, Orientações e Propostas, 2008.

PREFEITURA MUNICIPAL DE GUARULHOS - PMG. Plano Municipal de Água e Esgoto, 2011.

PREFEITURA MUNICIPAL DE GUARULHOS - PMG. PLHIS. Plano Municipal de Habitação de Interesse Social para Guarulhos , 2011.

PROSAB. Conservação de água e energia em sistemas prediais públicos de abastecimento de água. Rio de Janeiro: ABES, 2009. 352.p. 
QGIS, Development Team (2011).Quantum GIS Geographic Information System. Open Source Geospatial Foundation Project. Disponível em http://qgis.osgeo.org

REZENDE, Flavio Astolpho Vieira Souto; ALMEIDA, Renan M.Varnier; NOBRE, Flavio F. Diagramas de Voronoi para a definição de áreas de abrangência de hospitais públicos no Município do Rio de Janeiro. Cad. Saúde Pública, Rio de Janeiro , v. 16, n. 2, Junho 2000. Disponível em <http://www.scielo.br/scielo.php?script=sci_arttext\&pid=S0102311X2000000200017\&lng=en\&nrm=iso>. Acesso em 03 Setembro de. 2014.

RIBEIRO, V. O. Geotecnologias Aplicadas ao Saneamento Básico. 2011. Dissertação de Mestrado - Pós-Graduação em Tecnologias Ambientais, Universidade Federal do Mato Grosso do Sul, Campo Grande, 2011.

RIBEIRO, A. M. Gestão de Riscos Operacionais - GRO para um Sistema de Abastecimento de Água: ênfase no risco de escorregamentos no processo de distribuição. 2007. Dissertação de mestrado - Instituto de Pesquisas Tecnológicas, São Paulo, 2007.

ROSSMAN, L. EPANET 2 users manual. U. S. Environmental Protection Agency, Cincinnati, Ohio, 2000.

ROSTUM, J. Statistical modelling of pipe failures in water networks. 2000. $104 \mathrm{f}$. Tese (Doutorado) - Norwegian University Of Science And Technology, Trondheim, 2000.

SABESP. Situação dos mananciais. Disponível em: <http://site.sabesp.com.br >. Acesso em agosto de 2014.

SERVIÇO AUTÔNOMO DE ÁGUA E ESGOTO DE GUARULHOS - SAAE. Dados dos sistemas de água e esgoto. Disponível em: <www.saaeguarulhos.sp.gov.br>. Acesso em: agosto de 2014.

SERVIÇO AUTÔNOMO DE ÁGUA E ESGOTO DE GUARULHOS - SAAE. Estudos e projetos de implantação das Zonas de Medição e Controle (ZMCs), 2008.

SERVIÇO AUTÔNOMO DE ÁGUA E ESGOTO DE GUARULHOS - SAAE. PDSA Plano Diretor do Sistema de Abastecimento de Água do Municipio de Guarulhos, 2003

SERVIÇO AUTÔNOMO DE ÁGUA E ESGOTO DE GUARULHOS - SAAE. Serviços Técnicos de Engenharia para Atuar no Controle e Redução de Perdas do Sistema de Abastecimento de Água de Guarulhos, 2012.

SARZEDAS, G. L. Planejamento para a Substituição de Tubulações em Sistemas de Abastecimento de Água. Aplicação na Rede de Distribuição de Água da Região Metropolitana de São Paulo . 114 p. Dissertação para obtenção do título de mestre em Engenharia - Escola Politécnica da Universidade de São Paulo, São Paulo, 2009.

SAVINO, R. H.; FRANCISCO, P. C. Prevenção e atendimento a sinistros ocorridos em decorrência do rompimento de adutoras, redes de distribuição, ramais de água e retorno de esgoto sanitário em residências. 2005. 35ª ASSEMAE, Belo Horizonte, 2005.

SHAMIR, U. E HOWARD, C.D.D. An analytic approach to scheduling pipe replacement. 1979. Journal of AWWA, 71(5), 248-258

SILVA, R. T. Indicadores de perdas nos sistemas de abastecimento de água. Ministério do Planejamento e Orçamento. Secretaria de Política Urbana. Brasília, 1998 Documento Técnico de Apoio A2 do PROGRAMA NACIONAL DE COMBATE AO DESPERDÍCIO DE ÁGUA - Indicadores de Perdas nos Sistemas de Abastecimento de Água, Part. II Textos Explicativos. 
SNIS. SISTEMA NACIONAL DE INFORMAÇÕES SOBRE SANEAMENTO. Diagnóstico dos Serviços de Água e Esgotos - Ministério das cidades - Secretaria Nacional de Saneamento Ambiental, 2009.

SPÖRL, C.; ROSS, J. L. S. Análise comparativa de fragilidade ambiental com aplicação de três modelos. GEOUSP - Espaço e Ttempo. São Paulo. nº 15, p. 39-79. 2004.

TAGLIANI, C. R. A. Técnica para avaliação da vulnerabilidade ambiental de ambientes costeiros utilizando um sistema geográfico de informação. In: SEMINÁRIO BRASILEIRO DE SENSORIAMENTO REMOTO, 11., 2003, Belo Horizonte. Anais... São José dos Campos: INPE, 2003. p. 1657-1664.

TARDELli FILHO, J. Controle e redução de perdas. In: TSUTIYA, M. T. (Ed.). Abastecimento de água. São Paulo: Escola Politécnica da Universidade de São Paulo, 2006. cap. 10, p.457-525.

TOMINAGA, L. K.; SANTORO, J.; AMARAL, R. Desastres Naturais: Conhecer para prevenir. São Paulo: Instituto Geológico. 196 p. 2009.

TRICART, J. Ecodinâmica. Rio de Janeiro: SUPREN/IBGE, 1977. 91p.

TSUTIYA, M.T. (2004). Abastecimento de água. Departamento de Engenharia Hidráulica e Sanitária da Escola Politécnica da Universidade de São Paulo, São Paulo, 2004. 643p.

U.S. Geological Survey - USGS. Landslides Types and Processes. U.S. Geological Survey, Fact Sheet n. 2004- 3072, 4 p. 2004.

UZAN, E. F.. Questão de moradia: áreas de riscos naturais no Recreio de São Jorge e Novo Recreio, Guarulhos - SP. 2008. Dissertação de mestrado - Pontifícia Universidade Católica de São Paulo, 2008.

VARNES, D.J. Slope movement types and processes. In: SCHUSTER, R.L.; KRIZEK, R.J., eds., Landslides-Analysis and control: National Research Council, Washington, D.C., Transportation Research Board, Special Report 176, p. 11-33. 1978.

WALSKI, T.M.; PELLICCIA, A. (1982). Economic analysis of water main breaks. Journal of American Water Works Association, v. 74, n. 3, p. 140-147, mar. 1982. 